FACULDADE DE ECONOMIA, ADMINISTRAÇÃO E CONTABILIDADE DEPARTAMENTO DE CONTABILIDADE E ATUÁRIA

\title{
CONTRIBUIÇÃO PARA APURAÇÃO E EVIDENCIAÇÃO DOS RESULTADOS DAS INSTITUIÇÕES DE ENSINO SUPERIOR COM CERTIFICADO DE ENTIDADE BENEFICENTE DE ASSISTÊNCIA SOCIAL
}

EMANOEL MARCOS LIMA

Dissertação apresentada à Faculdade de Economia, Administração e Contabilidade da Universidade de São Paulo, para obtenção do título de Mestre em Controladoria e Contabilidade.

\section{SÃO PAULO}


UNIVERSIDADE DE SÃO PAULO

FACULDADE DE ECONOMIA, ADMINISTRAÇÃO E CONTABILIDADE DEPARTAMENTO DE CONTABILIDADE E ATUÁRIA

\section{CONTRIBUIÇÃO PARA APURAÇÃO E EVIDENCIAÇÃO DOS RESULTADOS DAS INSTITUIÇÕES DE ENSINO SUPERIOR COM CERTIFICADO DE ENTIDADE BENEFICENTE DE ASSISTÊNCIA SOCIAL}

EMANOEL MARCOS LIMA

Dissertação apresentada à Faculdade de Economia, Administração e Contabilidade da Universidade de São Paulo, para obtenção do título de Mestre em Controladoria e Contabilidade.

Orientador: Prof. Dr. Carlos Alberto Pereira

\section{SÃO PAULO}

2003 
"Em seu sentido mais pleno, a instrução mais perfeita é aquela que abarca a profundidade dos mistérios da fé e a perfeição da vida cristã." São Tomás de Aquino 
A minha esposa Eda e às minhas filhas Priscila e Jéssica razão maior do meu esforço, que com seu amor e carinho souberam me mostrar o quanto vale a pena viver com honestidade, respeito, dignidade e amor ao próximo. 


\section{AGRADECIMENTOS}

A Deus, Mestre Supremo, que me concedeu o dom da vida, sabedoria, inteligência e discernimento e que, com as suas graças, permitiu-me chegar até aqui.

Aos meus pais, José Pereira e Neuza, que, com seu esforço e dedicação, me proporcionaram condições à educação, possibilitando desta forma alcançar mais este degrau na minha vida profissional.

À minha esposa Eda, amiga e companheira, que sempre me apoiou e me incentivou sem jamais cobrar qualquer retribuição e que, sem o seu amor, esforço, carinho e dedicação, jamais seria possível concluir mais esta etapa.

Às minhas filhas, Priscila e Jéssica, que entenderam e compreenderam a minha ausência durante esse período e que através da sua alegria e simplicidade, me deram forças para superar as dificuldades.

Ao Prof. Dr. Edgard Bruno Cornachione Júnior que apesar das minhas dúvidas em expressar os objetivos do meu trabalho, me apoiou e orientou para que fosse possível a realização deste trabalho.

Ao Prof. Dr. Carlos Alberto Pereira, meu orientador, que, com seus conhecimentos, dedicação e orientação segura, possibilitou a conclusão deste trabalho, a minha eterna gratidão e o meu reconhecimento pela compreensão ante às minhas dificuldades. 
Aos professores do Mestrado, imprescindíveis na transmissão dos conhecimentos, rigorosos na exigência na busca do saber, porém companheiros nos momentos difíceis.

Ao Conselho Federal de Contabilidade, que, através da sua administração arrojada e do seu apoio institucional e financeiro, permitiu, através do convênio com a USP/Fipecafi/Unirondon, a realização deste Mestrado.

À direção da Faculdade Estácio de Sá de Campo Grande - MS, que, através do seu apoio institucional e financeiro, favoreceu a conclusão deste Mestrado.

Ao Pe. Giulio Boffi, ex-Pró-Reitor de Administração da Universidade Católica Dom Bosco que através do seu convite, permitiu que eu passasse a conhecer o problema deste trabalho, bem como a utilização das suas informações para fins de pesquisa deste trabalho.

Ao Pe. José Marinoni, Reitor da Universidade Católica Dom Bosco, pela sua preciosa colaboração na realização da pesquisa de campo.

À Amiga Claudia Neves, contadora da PUC/Rio, que, além de fornecer as informações necessárias para este trabalho, foi uma ouvinte incansável das minhas inquietações acerca dos problemas levantados.

Aos colaboradores da Auditec Auditoria e Contabilidade, que muito bem souberam conduzir os trabalhos na minha ausência, procurando solucionar todos os problemas, no sentido de não prejudicar os meus estudos.

Aos Amigos Olimpio e Valdiva, pessoas indispensáveis nas discussões, soluções dos problemas e na elaboração dos trabalhos e que com a sua amizade proporcionaram momentos de alegria e também de companheirismo nos períodos de dificuldades. 
Aos meus Amigos, Antonio João de Almeida, Francisco César Potrich, José Barreto dos Santos, Ordália Alves de Almeida, Viviane Gualberto Ferreira e Silvana Teves Alves, que me auxiliaram nos momentos de dificuldades.

Aos colegas do Mestrado, que pela convivência e pelas discussões calorosas e inflamadas, me permitiram aprender um pouco mais e a descobrir que pouco sabemos.

E a todas as pessoas que, direta ou indiretamente, me ajudaram, auxiliaram e incentivaram na busca do conhecimento, vibrando com cada vitória e, ao mesmo tempo, chorando quando fracassávamos, a todos vocês a minha gratidão e que Deus, na sua infinita bondade, retribua a vocês em dobro todos os gestos de carinho e amizade que dedicaram a mim. 


\section{SUMÁRIO}

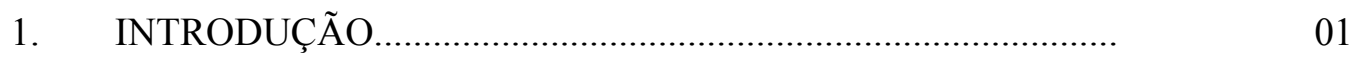

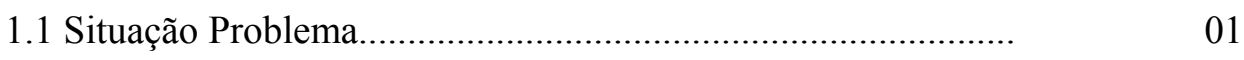

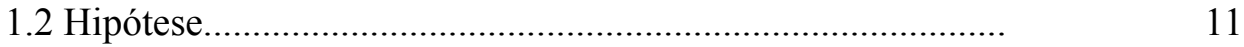

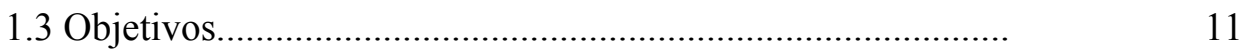

1.3.1 Objetivo Geral....................................................... 12

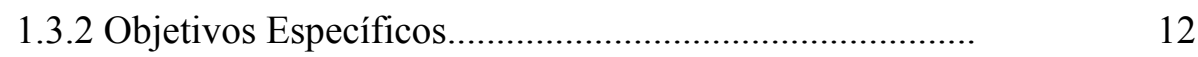

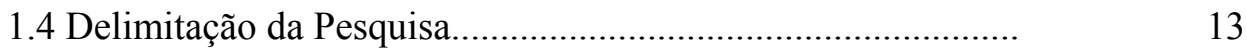

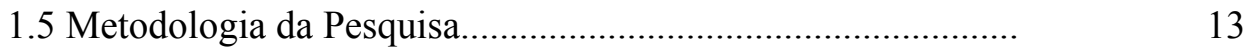

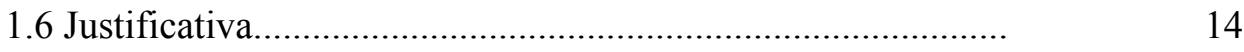

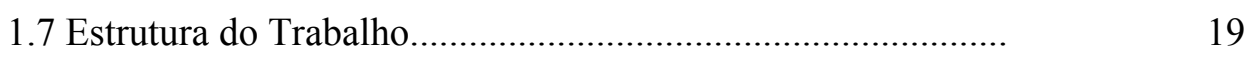

2. CARACTERIZAÇÃO DAS INSTITUIÇÕES DE ENSINO SUPERIOR COM CERTIFICADO DE ENTIDADE BENEFICENTE DE ASSISTÊNCIA SOCIAL ........................... 20

2.1 Breve História da Educação Superior no Brasil........................ 20

2.2 Finalidades da Educação Superior............................................ 24

2.3 Forma Jurídica das Instituições de Ensino Superior no Brasil.. 26

2.4 Gestão do Ensino Superior................................................. 28 
2.5 O que são Instituições de Ensino Superior com Certificado de Entidade Beneficente de Assistência Social.

2.6 Benefícios Fiscais das IESCEBAS

2.7 Características das IESCEBAS.

3. IDENTIFICAÇÃO DOS RESULTADOS DA PESQUISA............ 49

3.1 Planejamento da Pesquisa e Coleta de Dados...........................

3.2 Análise dos Resultados....................................................... 50

4. PROPOSTA DE APURAÇÃO E EVIDENCIAÇÃO DOS

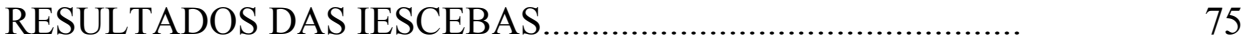

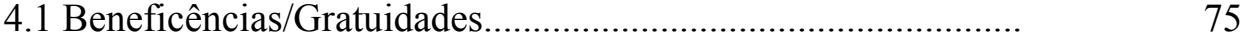

4.2 Custos, Receitas, Ativos e Passivos...........................................

4.3 Custo de Oportunidade.........................................................

4.4 Modelos Propostos...............................................................

4.4.1 Demonstração do Resultado............................................

4.4.2 Demonstração do Resultado com Certificado................... 87

4.5 Proposta de Lançamentos Contábeis...........................................

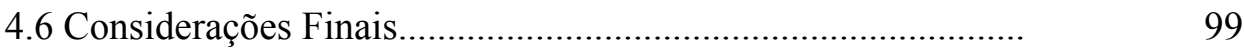

5. ANÁLISE DAS DEMONSTRAÇÕES CONTÁBEIS.................... 101

5.1 UCDB - Histórico e Caracterização............................................. 102

5.2 PUC/Rio - Histórico e Caracterização.......................................

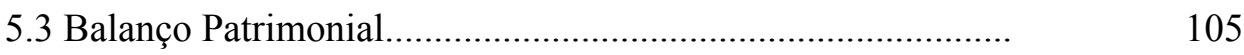

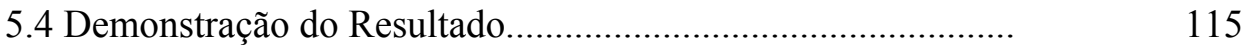

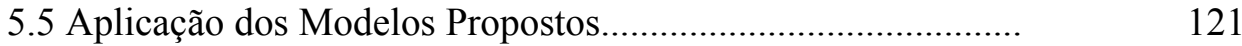


5.5.1 UCDB

122

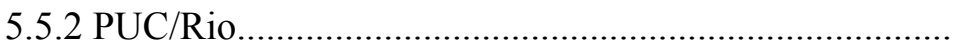

127

5.6 Sugestão de Aperfeiçoamento para NBC T 10.19....................

131

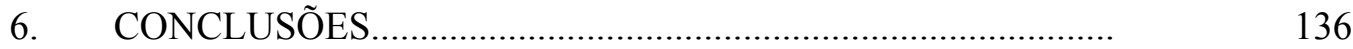

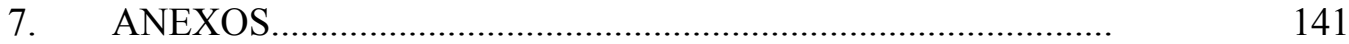

8. REFERÊNCIAS BIBLIOGRÁFICAS......................................... 153

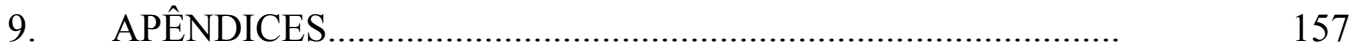




\section{LISTA DE FIGURAS}

Figura 1 - $\mathrm{O}$ ambiente e as instituições de ensino superior com certificado

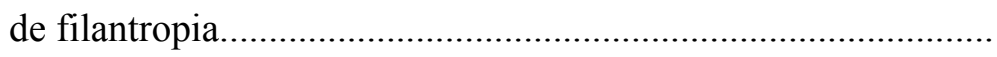

\section{LISTA DE QUADROS}

Quadro $01-\quad$ Conceito de IESCEBAS.................................................. 41

Quadro $02-\quad$ Benefícios Fiscais........................................................... 47 


\section{LISTA DE TABELAS}

Tabela 01 - Instituições pesquisadas....................................................... 53

Tabela $02-\quad$ Tempo de atividade....................................................... 55

Tabela 03 - Quantidade de alunos...................................................... 56

Tabela $04-\quad$ Setor contábil............................................................... 57

Tabela 05 - Tempo que a instituição possui o certificado......................... $\quad 58$

Tabela 06 - Alunos atendidos pela beneficência....................................... 59

Tabela $07-\quad$ Valor gasto com beneficência.............................................. 60

Tabela 08 - Áreas de atuação.............................................................. 61

Tabela 09 - Percentual de cada área de atuação......................................... 62

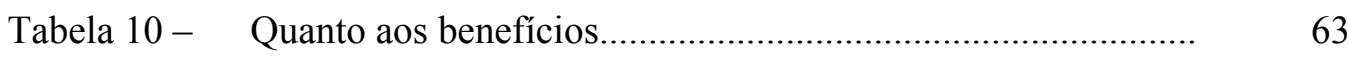

Tabela 11 - Relação gastos com beneficências x benefícios........................ 64

Tabela 12 - Obrigações da instituição....................................................... 66

Tabela 13 - Forma de contabilização das beneficências.............................. 67

Tabela 14 - $\quad$ Apuração dos custos........................................................... $\quad 68$

Tabela 15 - Forma de contabilização dos benefícios.................................... 69

Tabela 16 - Apuração de resultado....................................................... 70

Tabela 17 - $\quad$ Demonstração dos resultados................................................ 71

Tabela 18 - Apuração do resultado total................................................ 72

Tabela $19-\quad$ Relatórios apresentados.................................................... 73

Tabela 20 - NBC T 10.19 do CFC.......................................................... 74 
Tabela 21 - $\quad$ Modelo de Demonstração do Resultado................................... $\quad 86$

Tabela 22 - Modelo de Demonstração do Resultado com Certificado........ $\quad 88$

Tabela 23 - Contabilização da Receita.................................................... 93

Tabela 24 - Contabilização dos Custos e Despesas...................................... 94

Tabela 25 - Contabilização da Obrigação.................................................... 94

Tabela 26 - Contabilização das Despesas..................................................... 95

Tabela 27 - Contabilização dos Benefícios................................................... 95

Tabela 28 - Contabilização das Beneficências.......................................... 96

Tabela 29 - Contabilização dos Custos do Certificado................................. 96

Tabela 30 - Certificado do Encerramento.................................................. 97

Tabela 31 - Aplicação do Modelo de Demonstração do Resultado............. 99

Tabela 32 - Balanços Patrimoniais UCDB............................................. 107

Tabela 33 - Balanços Patrimoniais PUC/Rio................................................ 109

Tabela 34- Demonstrações dos Resultados UCDB................................... 116

Tabela 35 - Demonstrações dos Resultados PUC/Rio................................ 117

Tabela 36 - Proposta de Demonstração dos Resultados UCDB................. 122

Tabela 37 - Despesas Administrativas UCDB........................................ 139

Tabela 38 - Proposta de Demonstração dos Resultados com Certificado

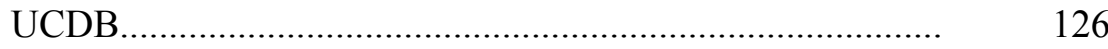

Tabela 39 - Proposta de Demonstração dos Resultados PUC/Rio............. $\quad 127$

Tabela 40 - Despesas Administrativas PUC/Rio..................................... 129

Tabela 41 - Proposta de Demonstração dos Resultados com Certificado PUC/Rio.................................................................. $\quad 130$ 


\section{LISTA DE GRÁFICOS}

Gráfico $01-\quad$ Tempo de atividade...................................................... $\quad 55$

Gráfico $02-\quad$ Quantidade de alunos.................................................... 56

Gráfico 03 - Setor contábil............................................................ 57

Gráfico $04-\quad$ Tempo que a instituição possui o certificado........................ 58

Gráfico 05 - Alunos atendidos pela beneficência..................................... 59

Gráfico 06 - Valor gasto com beneficência............................................. 60

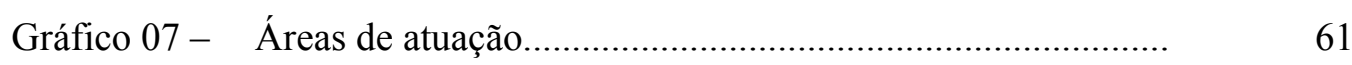

Gráfico 08 - Quanto aos benefícios...................................................... 63

Gráfico 09 - Relação gastos com beneficências x benefícios..................... 64

Gráfico 10 - Obrigações da instituição...................................................... 66

Gráfico 11 - Forma de contabilização das beneficências........................... 67

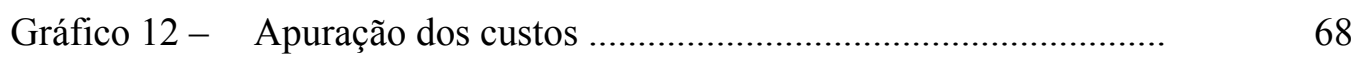

Gráfico 13 - Forma de contabilização dos benefícios................................ 69

Gráfico 14 - Apuração de resultado..................................................... $\quad 70$

Gráfico 15 - Demonstração dos resultados........................................... 71

Gráfico 16 - Apuração do resultado total...............................................

Gráfico 17 - Relatórios apresentados................................................. 73

Gráfico 18 - $\quad$ NBC T 10.19 do CFC ..................................................... 74 


\section{LISTA DE ABREVIATURAS}

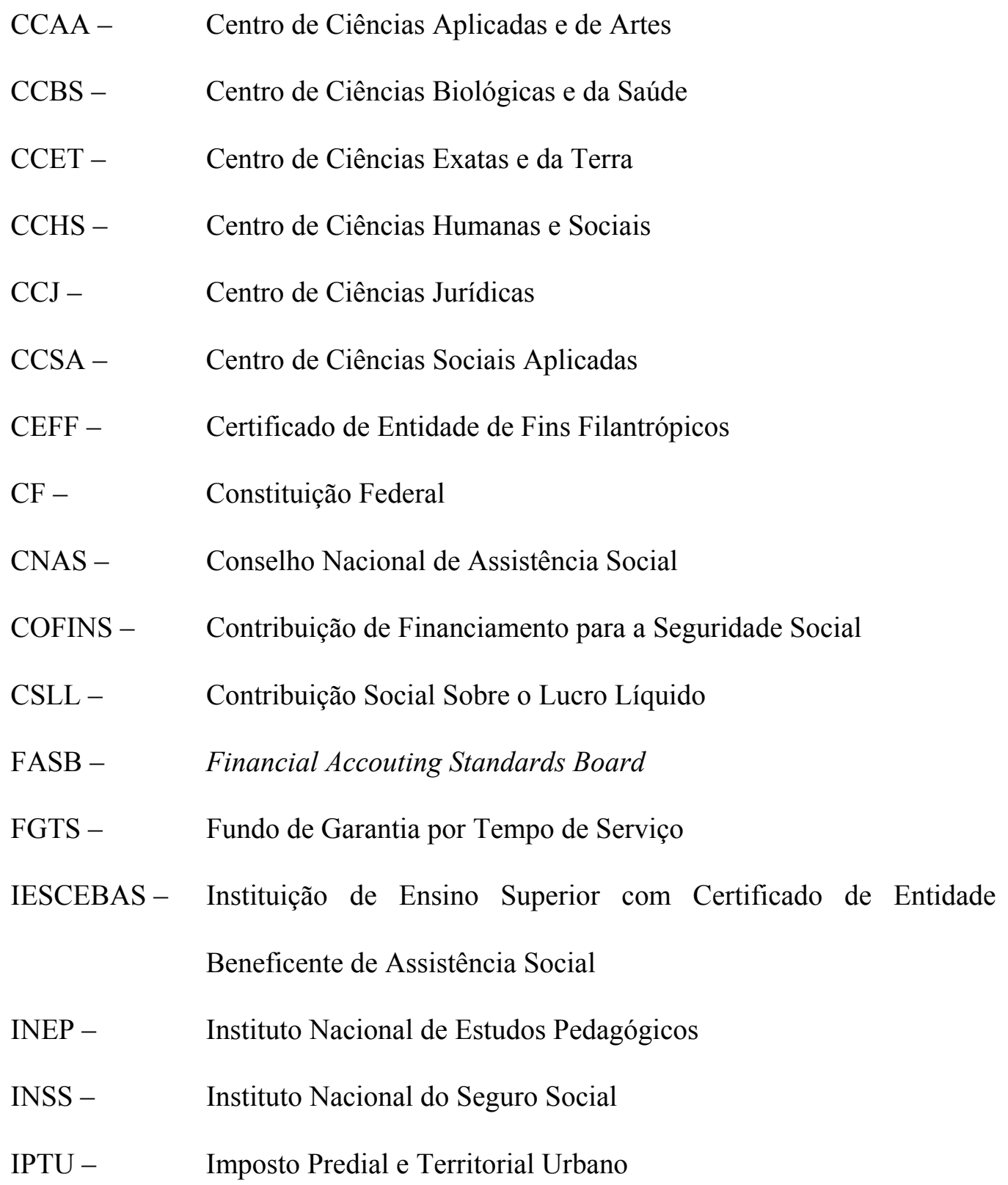




$\begin{array}{ll}\text { IPVA - } & \text { Imposto Sobre Propriedade de Veículo Automotor } \\ \text { ISSQN - } & \text { Imposto Sobre Serviços de Qualquer Natureza } \\ \text { ITBI - } & \text { Imposto Sobre Transmissão de Bens Imóveis e de Direitos a Eles } \\ & \text { Relativos } \\ \text { ITCD - } & \text { Imposto Sobre a Transmissão Causa Mortis e Doação de Quaisquer } \\ \text { LDB - } & \text { Lens ou Direitos } \\ \text { MSMT - } & \text { Missão Salesiana de Mato Grosso } \\ \text { NBC T - } & \text { Norma Brasileira de Contabilidade Técnica } \\ \text { PIS - } & \text { Programa de Integração Social } \\ \text { PUC - } & \text { Pontifícia Universidade Católica } \\ \text { UCDB - } & \text { Universidade Católica Dom Bosco }\end{array}$




\section{RESUMO}

O objetivo deste trabalho é contribuir com o aperfeiçoamento das informações contábeis para a gestão das Instituições de Ensino Superior com Certificado de Entidade Beneficente de Assistência Social - IESCEBAS, por meio da proposição de um modelo de apuração e evidenciação do resultado com o Certificado de Entidade Beneficente de Assistência Social. O estudo desenvolve-se a partir da análise dos seguintes aspectos: caracterização e definição de uma IESCEBAS, processo de gestão e sistemas de informações com base numa abordagem sistêmica. Os gestores, governo e sociedade necessitam de informações úteis e confiáveis sobre os resultados com o CEBAS para a tomada de decisões. Porém, conforme se constatou pela pesquisa de campo realizada por meio de questionários e análises das demonstrações contábeis, que a prática adotada pelas instituições objeto de estudo e também a norma editada pelo Conselho Federal de Contabilidade, não são adequadas para fornecer informações que subsidiem os gestores, governo e sociedade na tomada de decisões. Ao discorrer sobre os conceitos de receitas, custos, ativos, passivos e custo de oportunidade, conclui-se que o CEBAS gera impactos patrimoniais e econômicos que devem ser apurados e evidenciados pela contabilidade. Contudo, verificou-se pela análise dos resultados da pesquisa de campo, que não existe clareza quanto aos procedimentos contábeis e à legislação aplicáveis na apuração e evidenciação desses impactos pela contabilidade. A partir desta constatação, é proposto um modelo de apuração e evidenciação dos resultados com o certificado das IESCEBAS, de modo a subsidiar os gestores, governo e sociedade na tomada de decisões. Ao final, o modelo proposto é aplicado ao caso de duas IESCEBAS, com a finalidade de verificar sua utilidade.

Palavras-chave: Certificado, Beneficência e Custo de Oportunidade. 


\begin{abstract}
This study aims to contribute to the improvement of accounting information for administering Higher Education Institutions with a Philanthropy Certificate IESCEBAS, through the proposal of a model for verifying and disclosing the income obtained through the Philanthropy Certificate. The study is based on the analysis of the following aspects: characterization and definition of an IESCEBAS, management process and information systems on the basis of a systemic approach. The managers, government and society need useful and trustworthy information about the results obtained through the Philanthropy Certificate with a view to decision-making. Nevertheless, as we observed from the field research held by means of questionnaires and from the analysis of the financial statements, the practice adopted by the institutions in this study as well as the norm issued by the Brazilian Federal Accounting Council are not adequate to supply information that assists the managers, government and society in decision-making. Our discussion of the revenues, costs, assets, liabilities and opportunity cost concepts leads us to the conclusion that the Philanthropy Certificate generates equity and economic impacts that have to be verified and disclosed by accounting. However, we observed from the analysis of the field research results that there are uncertainties with respect to the accounting procedures and legislation that should be applied in the verification and disclosure of these impacts by accounting. On the basis of this observation, we propose a model for verifying and disclosing the income obtained through the Philanthropy Certificate, so as to assist the managers, government and society in making decisions. Finally, the proposed model is applied to two IESCEBAS, with a view to verifying its usefulness.
\end{abstract}

Keywords: Certificate, Philanthropy and Opportunity Cost. 


\section{CAPÍTULO 1 - INTRODUÇÃO}

\subsection{Situação Problema}

Nos últimos anos, muitas mudanças sociais e políticas têm ocorrido no mundo muito rapidamente, fazendo com que as pessoas sejam obrigadas a acompanhar essas mudanças. As sociedades mudam com grande velocidade, gerando incertezas e esperanças aos agentes sociais, que se sentem pressionados a adaptar-se às novas realidades como forma de se estabelecer diante das novas circunstâncias. $\mathrm{O}$ processo de globalização fez com que aumentasse a competitividade entre os mercados, tornando o empreendedor um forte aliado na busca de alternativas para vencer as batalhas da competição. As relações de produção, otimizadas pela informática, tecnologia e a ciência, reiteram um novo pensar sobre a formação das profissões, diante das novas necessidades exigidas pela própria sociedade civil. Não se pode negar a realidade apresentada pela globalização dos mercados, que contorna o mundo atual, mas defender uma metodologia que permita às pessoas construir uma visão de mundo real e concreta, sabedoras não apenas da sua área de atuação, que, inegavelmente, deve atender às exigências do mercado de trabalho, mas que seja uma busca livre e autônoma do conhecimento e da reflexão crítica e independente sobre o sistema social vigente.

Vivemos em uma época em que está ocorrendo uma transformação na 
natureza do trabalho e a era da industrialização está sendo substituída pela era da informação. As relações de trabalho são discutidas, as máquinas substituem as pessoas, trazendo sérias preocupações para a sociedade civil. A revolução tecnológica, ocorrida nas últimas décadas, tem exigido dos indivíduos uma busca constante por informações, na esperança de acompanharem as transformações que ocorrem nas relações de trabalho. Diante dessa realidade, o setor educacional tornouse um forte instrumento, com a difícil missão de formar cidadãos honestos e competentes, capazes de atender à demanda da sociedade.

BENEDICTO (1997:20) afirma "que a sociedade se desenvolveu e continua se desenvolvendo em grande parte como resultado da ação das instituições de ensino. O esforço isolado de uma pessoa não poderia realizar tanta coisa dentro da sociedade como as entidades de ensino o têm feito".

As relações sociais de trabalho estão intimamente ligadas à formação do indivíduo. O Estado possui várias funções institucionais, que visam a atender às necessidades da sociedade. GRAMSCI apud COUTINHO (1981:91-92) aponta duas funções essenciais no interior do Estado:

“(...) 'a sociedade política' (Estado-coerção) que é formada pelo conjunto de mecanismos, através dos quais a classe dominante detém o monopólio legal da repressão e da violência, e que se identifica com o aparelho de coerção sob controle das burocracias executiva e policial militar; 'a sociedade civil, formada precisamente pelo conjunto das organizações responsáveis pela elaboração e ou difusão das ideologias, compreendendo o sistema escola, as igrejas, os partidos políticos, os sindicatos, as organizações profissionais, a organização material da cultura (revistas, jornais, editoras, meios de comunicação de massa) etc."

$\mathrm{Na}$ análise de Gramsci, a sociedade civil realiza uma função implícita no 
contexto da realidade social, através da sua forma de organização. Assim, de acordo com SANTOS (2001:32):

"Os meios de comunicação, as universidades, as escolas, as igrejas, os sindicatos etc., como instituições aparentemente neutras, por meio de uma prática social especifica, acabam reiterando uma concepção de mundo que contribui para 'conservar a unidade ideológica de todo bloco social'".

Sendo assim, cabe ao Estado definir e direcionar toda a política educacional do país, conforme prescreve o Art. 205 da Constituição Federal de 1988-CF/88:

“A educação, direito de todos e dever do Estado e da familia, será promovida e incentivada com a colaboração da sociedade, visando ao pleno desenvolvimento da pessoa, seu preparo para o exercício da cidadania e sua qualificação para o trabalho".

Nesse aspecto, Estado e Sociedade Civil devem unir-se na busca de alternativas para atender ao interesse público, ou seja, o bem comum, satisfazendo, dessa forma, às expectativas da sociedade quanto à formação das pessoas, estando assim preparadas para enfrentar os desafios proporcionados pelo mercado de trabalho.

O Art. 45 da Lei $n^{\circ} 9394$ de 20 de dezembro de 1996, que trata das diretrizes e bases da educação nacional, prescreve: “A educação superior será ministrada em instituições de ensino superior, públicas ou privadas, com variados graus de abrangência ou especialização"

Diante da importância do ensino para a nação, foram criadas leis no sentido de favorecer o acesso às pessoas com menos poder aquisitivo.

Nesse sentido, o Art. 150 da CF/88 prescreve: 
“Sem prejuízo de outras garantias asseguradas ao contribuinte, é vedado à União, aos Estados, ao Distrito Federal e aos Municípios:

(...)

VI - instituir impostos sobre:

c) patrimônio, renda ou serviços dos partidos políticos, inclusive suas fundações, das entidades sindicais dos trabalhadores, das instituições de educação e de assistência social, sem fins lucrativos, atendidos os requisitos da lei;"

Segundo CHIESA (2000:248), “o objetivo do legislador, no art. 150, IV, “c”, da CF/88, não foi o de conferir a um determinado tipo de pessoa jurídica certos benefícios, mas a qualquer pessoa jurídica sem fins lucrativos”. O entendimento do autor é que, com a concessão dos benefícios, o legislador almejava motivar os cidadãos a constituírem pessoas jurídicas com a finalidade de auxiliar o Estado em seu fim institucional de proporcionar educação a todos, principalmente aos menos favorecidos.

Ao proibir a fixação de impostos sobre as instituições de ensino sem fins lucrativos, o Estado acreditava estar criando oportunidades de acesso à educação a todas as pessoas.

Para auxiliar o Estado, em seu fim institucional, surgiram as Instituições de Ensino Superior com Certificado de Entidade Beneficente de Assistência SocialIESCEBAS. Essas instituições, além dos benefícios estabelecidos na Constituição Federal, gozam também dos benefícios estabelecidos no Art. $55^{\circ}$ da Lei Orgânica da Seguridade Social no 8.212, de 24 de julho de 1991, que serão abordados no capítulo 2 deste trabalho. 
Para usufruírem os benefícios gerados pela concessão do Certificado de Entidade de Beneficente de Assistência Social - CEBAS, as instituições, segundo o Inciso VI do Art. $3^{\circ}$ do Decreto $n^{\circ} 2536$, de 6 de Abril de 1998, devem:

"Aplicar anualmente, em gratuidade, pelo menos vinte por cento da receita bruta proveniente da venda de serviços, acrescida da receita decorrente de aplicações financeira, de locação de bens, de venda de bens não integrantes do ativo imobilizado e de doações particulares, cujo montante nunca será inferior à isenção de contribuições sociais usufruidas."

Constata-se, pois, que, para as instituições fazerem jus aos benefícios (isenções das contribuições para a seguridade social), incorrerão em custos (aplicações em gratuidades) necessários para o cumprimento do percentual que deve ser aplicado em gratuidade.

Percebe-se, diante do exposto, a ocorrência de eventos econômicos, que são fenômenos que transformam o patrimônio da empresa e, portanto, geram os seus resultados. Esses fenômenos decorrem das decisões dos gestores, que se referem, nesse caso, basicamente, aos benefícios recebidos em função do certificado e à aplicação de recursos em gratuidade. Esses eventos, produzirão resultados econômicos para a instituição, independente da ação dos gestores, haja vista a instituição ter tomado a decisão de ter o certificado.

Diferentemente das instituições de ensino superior com fins lucrativos, as IESCEBAS não visam ao acúmulo de riquezas com a finalidade de remunerar o capital dos fundadores, mantenedores, etc., e sim ao cumprimento dos seus objetivos sociais e à continuidade da instituição. Entretanto, para a realização desses, essas instituições necessitam de recursos materiais, humanos, financeiros e tecnológicos, 
etc. A principal fonte de recursos é a mensalidade escolar paga por seus alunos. Essas instituições, apesar de serem sem fins lucrativos, sofrem concorrência tanto na obtenção de recursos quanto na colocação de seus produtos e serviços a seus clientes, e precisam assegurar a sua continuidade para alcançar seus objetivos.

Ao competir por recursos, seja qual for sua natureza, a empresa encontra diversas alternativas no mercado para o emprego desses recursos. Enquanto isso, os concorrentes diretos oferecem a seus clientes os mesmos produtos com condições diferenciadas, devendo, dessa forma, prestar serviço com baixo preço e ótima qualidade.

Sobre a competitividade da empresa, PEREIRA in CATELLI (2001:45) afirma "que ela pode ser caracterizada tanto sob a ótica do mercado consumidor (cliente) de seus produtos, quanto sob a ótica do mercado fornecedor dos recursos necessários a suas atividades".

Existe, segundo o autor, um mercado alternativo que concorre permanentemente com as atividades internas da empresa.

Sobre essa questão, PEREIRA in CATELLI (2001:46) afirma:

"A existência de mercados alternativos requer da empresa uma ampliação da sua visão de negócios, desenvolvendo sua competitividade não apenas em relação aos seus produtos finais, mas também em todas as atividades que desenvolve internamente ou sejam requeridas para seu negócio principal".

Todas as atividades internas da organização devem ser competitivas, contribuindo de forma favorável ao resultado global da organização e, caso isso não ocorra, devem-se buscar no mercado alternativas que melhorem os resultados da organização, não justificando a manutenção dessas atividades no ambiente interno da 
organização.

Para manter a sua continuidade, as IESCEBAS necessitam administrar bem os recursos disponíveis, bem como zelar pela manutenção do seu patrimônio.

Nesse contexto, a Contabilidade apresenta-se como um forte instrumento no controle do patrimônio das instituições, sendo essa função reconhecida através do Princípio Contábil da Entidade aprovado pela Resolução 750 de 29.12.93, que estabelece:

"o Patrimônio como objeto da Contabilidade e afirma a autonomia patrimonial, a necessidade da diferenciação de um patrimônio particular no universo dos patrimônios existentes, independentemente de pertencer a uma pessoa, um conjunto de pessoas, uma sociedade ou instituição de qualquer natureza ou finalidade, com ou sem fins lucrativos".

A Contabilidade, como ciência que controla o patrimônio das entidades, deve fornecer informações necessárias para o seu acompanhamento.

Sobre essa questão, IUDÍCIBUS (1992:116) afirma:

"A contabilidade é uma ciência com técnicas especificas e designada a estudar e controlar o patrimônio das entidades, do ponto de vista econômico e financeiro, observando seus aspectos quantitativos e qualitativos bem como suas variações, com o objetivo de fornecer informações sobre o estado patrimonial em determinado periodo".

Enfatizando a importância das informações para os dirigentes das entidades sem fins lucrativos, MARTINS (2000:01) afirma:

"Comumente na direção dessas entidades não se encontram profissionais com vivência em contabilidade, em finanças ou mesmo em administração. Com isso, acaba o contabilista, responsável por essa entidade, cumprindo o papel de assessor, que muito melhor pode desempenhar quando fizer 
realmente bom uso gerencial da contabilidade. E toda a experiência mostra que uma contabilidade bem elaborada e produzida à base de critérios sadios é de extraordinária importância para a avaliação de desempenho e para controle dessas entidades, mormente quando dirigidas por profissionais não especializados".

Nos últimos anos, muito se tem discutido e publicado sobre os caminhos da filantropia, caminhos por onde passam também as instituições objeto deste estudo. Muitas instituições têm tido seu certificado cassado pelo CNAS, por conta de não conseguir demonstrar corretamente os gastos com beneficência exigidos por lei, prova disso, é a matéria publicada, em 17 de abril de 2001, através da Agência Estado com o seguinte título: CNAS cassa 105 entidades filantrópicas. Recentemente, instituições como: Fundação Cásper Libero, Universidade Mackenzie, Faculdades Metodista e Universidade Gama Filho, não tiveram seus certificados renovados pelo CNAS.

Muitas críticas estão sendo feitas aos profissionais da Contabilidade que, ao seu critério, manipulam os dados das demonstrações financeiras, no sentido de atender às necessidades dos seus clientes.

Demonstrar, apenas, em Notas Explicativas, os gastos e os benefícios oriundos do Certificado, conforme estabelece a NBC T 10.19 e também o Parágrafo Único do Art. $4^{\circ}$ do Decreto 2536, facilita em muito a ação dos “pilantrópicos".

Os gestores, governo e a sociedade, necessitam saber de forma clara e transparente qual o valor dos benefícios recebidos, bem como, onde e como, os mesmos foram aplicados. Essas informações ajudam a todos os interessados a procederem à análise sobre a concessão de benefícios gerados pelo certificado.

A Contabilidade, como um instrumento de informação, deve representar 
para a sociedade um mecanismo de controle para os recursos pagos por ela própria, entretanto, administrados por essas instituições.

No exercício das nossas atividades profissionais, verificamos que a instituição em que trabalhamos e que possui o certificado, não contabiliza os benefícios fiscais e também não apura e nem evidencia os resultados obtidos com o certificado, entretanto os custos são contabilizados em contas de resultado.

Procurou-se, a partir dessa constatação, verificar se essa situação era particular, mas se outras instituições também adotavam esse procedimento. Após alguns contatos a outras IESCEBAS e também a uma entidade de representação dessas instituições, constatou-se que o procedimento adotado era idêntico e que o mesmo era recomendado pela entidade consultada.

Buscou-se, então, realizar pesquisa no sentido de encontrar subsídios e elementos que justificassem tal procedimento. Para surpresa, não foi encontrada nenhuma bibliografia que caracterizasse essas instituições e que fundamentasse tais procedimentos. Encontrou-se matéria publicada na revista do IBRACON do mês de Setembro de 1999 do Prof. Luis Martins de Oliveira, recomendando a utilização de contas de compensação para o registro dos benefícios recebidos e gratuidades aplicadas.

As normas e os procedimentos contábeis aplicados às IESCEBAS são bem limitadas. A NBC T 10.19, editada pelo Conselho Federal de Contabilidade, no item 10.19.1.1 das Disposições Gerais estabelece:

"critérios e procedimentos especificos de avaliação, de registros dos componentes e variações patrimoniais e de estruturação das demonstrações contábeis, e as informações mínimas a serem divulgadas 
em nota explicativa das entidades sem finalidades de lucros."

Os critérios e procedimentos contidos na NBC $\mathrm{T}$ 10.19, apesar de contemplarem as situações que ocorrem nas IESCEBAS, com relação aos benefícios fiscais e gratuidades, contraria os princípios fundamentais de Contabilidade, principalmente no que diz respeito ao princípio da competência (Anexo A).

Diante do que foi apresentado, deduz-se que:

Se:

- O certificado gera eventos econômicos e, conseqüentemente, produz resultados.

- A Contabilidade é uma ciência que mensura e controla o patrimônio e suas variações.

- O resultado com o certificado é uma informação importante para a gestão das IESCEBAS, governo e sociedade.

- A prática e as normas contábeis aplicáveis não são adequadas para apurar e evidenciar os resultados com o certificado.

Então: Os resultados com o certificado devem ser apurados e evidenciados pela Contabilidade, de modo a subsidiar a gestão das IESCEBAS, governo e sociedade na tomada de decisão.

Diante das situações apresentadas e da necessidade de a Contabilidade prestar informações verdadeiras para os gestores, governo e sociedade, apresenta-se a seguinte questão que o estudo buscará responder:

Como a Contabilidade pode apurar e evidenciar os resultados com o 
certificado de modo a subsidiar a gestão das IESCEBAS, o governo e a sociedade na tomada de decisão?

\subsection{Hipótese}

Para responder à questão formulada, estabeleceu-se a seguinte hipótese:

Os resultados com certificado podem ser apurados pela Contabilidade através do confronto entre os custos (beneficências) e benefícios (isenção das contribuições sociais) e evidenciados nas demonstrações contábeis das IESCEBAS.

Se confirmada essa hipótese, então, constata-se a necessidade de aperfeiçoamento das informações contábeis, de modo a subsidiar a gestão das IESCEBAS, governo e sociedade na tomada de decisão.

\subsection{Objetivos}

A partir da situação-problema e justificativa do trabalho apresentado, a pesquisa desenvolveu-se com os seguintes objetivos:

\subsubsection{Geral}

Contribuir com o aperfeiçoamento das informações contábeis para a gestão das IESCEBAS, por meio da proposição de um modelo de apuração e evidenciação do resultado com o Certificado de Entidade Beneficente de Assistência Social.

\subsubsection{Específicos}


a)

identificar as principais características das IESCEBAS no que se refere a: história da educação superior no Brasil, finalidades, forma jurídica, conceituação, benefícios fiscais, gestão do ensino superior e sistemas de informações;

b) verificar os conhecimentos por parte das IESCEBAS referentes à legislação pertinente à concessão do CEBAS;

c) identificar e analisar os procedimentos contábeis ao tratamento adotado pelas IESCEBAS, particularmente no que se refere à apuração e evidenciação dos resultados obtidos com o certificado;

d) apresentar uma proposta de modelo de apuração e demonstração do resultado contábil com o certificado dessas instituições;

e) aplicação do modelo proposto ao caso de duas IESCEBAS, como forma de comparar o modelo proposto com o modelo utilizado;

f) apresentar sugestões para aperfeiçoamento da NBC T 10.19.

\subsection{Delimitações da Pesquisa}

Existem, no Brasil, vários tipos de instituições de ensino superior, que atuam em diversas áreas do conhecimento. Esta pesquisa está voltada para as Instituições de Ensino Superior portadoras do Certificado de Entidade Beneficente 
de Assistência Social, com base nos dados de 2000 e 2001, que atuam no Brasil, sem restrição quanto à sua área de atuação, observando, apenas, os aspectos tangíveis.

O ponto central da pesquisa são as informações contábeis das IESCEBAS. O estudo dos procedimentos contábeis, estabelecidos pela NBC T 10.19 do Conselho Federal de Contabilidade, permitir-nos-á compreender, analisar e contribuir para a melhoria das informações contábeis.

\subsection{Metodologia da Pesquisa}

CERVO e BERVIAN (1996:20) afirmam que:

"Em seu sentido mais geral, o método é a ordem que se deve impor aos diferentes processos necessários para atingir um fim dado ou um resultado desejado. Nas ciências, entende-se por método o conjunto de processos que o espírito humano deve empregar na investigação $e$ demonstração da verdade”.

O método utilizado na pesquisa foi o hipotético dedutivo defendido por POPPER, visto que se parte de um problema, estabelece-se uma hipótese geral e procura-se testá-la visando à sua confirmação ou não e por fim é proposto uma solução, num ambiente específico.

A revisão bibliográfica e documental foi fator fundamental para a solução dos problemas apresentados. Os dados colhidos tiveram como base livros, teses e dissertações, revistas especializadas, publicações em periódicos, além de artigos disponibilizados pela internet e anais de congressos, que deram suporte teóricometodológico ao processo de análise dos resultados.

A fundamentação deste estudo também teve por base uma pesquisa empírica junto aos contabilistas das IESCEBAS, no sentido de verificar a existência do 
problema. A coleta de dados deu-se através de questionário enviado pelo correio ao Reitor ou Diretor dessas instituições, aos quais foi solicitado que o enviassem aos contabilistas para que o respondessem.

Para identificar e analisar os procedimentos contábeis adotados pelas IESCEBAS, o presente trabalho apresenta análise das demonstrações contábeis da Universidade Católica Dom Bosco - UCDB, estabelecida em Campo Grande - MS e Pontifícia Universidade Católica - PUC/Rio, estabelecida no Rio de Janeiro - RJ.

\subsection{Justificativa}

A realidade do nosso país ainda é triste, quando é abordado o assunto educação, principalmente no que se refere ao ensino superior. Felizmente, essa realidade, segundo dados do Ministério da Educação ${ }^{1}$, tem mudado.

\footnotetext{
${ }^{1}$ Fonte MEC - http://www.mec.gov.br/acs/ftp/tabela/fatos.doc acesso em 19.08.2002.
} 
Houve uma grande expansão no número de estudantes nos cursos de graduação no período de 1994 a 2000. Entre 1997 e 2000, período em que ocorreu o maior crescimento, a taxa de expansão foi de $11 \%$ ao ano. Esse percentual, para se ter uma idéia do crescimento, é quase o mesmo atingido em toda a década de 80 que foi de $12 \%$. Ao contrário do que ocorre na educação básica, onde a rede pública é majoritária, esse aumento é justificado pelo crescimento do número de vagas oferecidas pelas instituições particulares que cada vez mais estão ampliando o número de formandos nas universidades e em instituições de ensino superior. O percentual de formandos saltou de 6\% no período de 1989 a 1994 e para 32\% a partir de 1994. Em 1999, segundo a pesquisa, para cada 100 estudantes que ingressaram em 1994, 70 concluíram seus cursos, ficando clara a importância do ensino superior para a formação de profissionais com melhor qualificação e preparados para uma intervenção social mais responsável.

O Art. 208 da CF/88 estabelece quais os níveis de ensino em que o Estado tem dever para com a educação, deixando claro que o dever do Estado é somente com os níveis fundamental e médio. Ao excluir do texto constitucional o nível superior como dever do Estado, o mesmo enfatiza, conforme consta do texto, que esse nível será desenvolvido “com a colaboração da sociedade”, no sentido de que esta também possa contribuir para a formação do cidadão. O Estado, ao solicitar a participação da sociedade civil na formação das pessoas, reconhece a sua incapacidade em atender a todas as necessidades educacionais dos indivíduos. Para tanto, o Estado favorece a sociedade, no sentido de proporcionar o ensino a um custo menor.

O setor educacional no Brasil tem sofrido grandes e profundas alterações 
nos últimos anos. O Governo Federal tem editado Leis que regulam e direcionam o ensino no país. A Lei n ${ }^{\circ}$ 9.394, de 20 de dezembro de 1996, estabeleceu as diretrizes e bases da educação nacional, definindo, dessa forma, os critérios e mecanismos de funcionamento do ensino no país.

O aumento de pessoas com nível superior é importante para o desenvolvimento sustentado do país. Os novos processos de produção exigem profissionais cada vez mais qualificados. $O$ aumento das condições de empregabilidade e a redução das taxas de desemprego ocorrem quando o acesso ao nível superior é aumentado. De acordo com dados do Ministério da Educação, caso seja mantido a taxa média de crescimento de $7 \%$ ao ano, verificada no período de 1994 a 1998, o ensino superior brasileiro terá cerca de três milhões de alunos matriculados em cursos de graduação em 2004. Para atender à demanda projetada, devem ser abertas 875 mil novas vagas, nos próximos cinco anos, sendo 542 mil nas instituições particulares e 333 mil nas instituições públicas. Essa estimativa considera que a distribuição da matrícula entre públicas e particulares mantenha-se em $38 \%$ e $62 \%$ respectivamente.

As responsabilidades das instituições de ensino superior são enormes, haja vista o seu grande papel social, exigindo delas elevada competência administrativa, na busca do cumprimento dos seus objetivos sociais. Essas finalidades, além de serem fiscalizadas pelo Ministério da Educação, através dos seus instrumentos de avaliação, são verificadas pela sociedade, que, através do mercado, avaliam a qualidade do ensino que cada instituição está oferecendo. Essa situação acaba por gerar uma concorrência entre as instituições, no sentido de atender às necessidades do mercado, visto que cada uma quer oferecer ao mercado um produto com melhor 
qualidade a um preço menor. Nesse aspecto, importante ressaltarem-se as necessidades dos dirigentes por informações que os auxiliem na tomada de decisões, que serão necessárias para o cumprimento da missão da instituição.

Segundo dados do Conselho Nacional de Assistência Social - CNAS², são 6.775 entidades filantrópicas, sendo $71 \%$ delas no segmento de assistência social, $17 \%$ no segmento saúde e $12 \%$ no segmento educação, todavia, conforme resposta do próprio CNAS, dentro do segmento educação o mesmo não possui banco de dados separado por nível escolar, não sendo possível informar qual o número de instituições de ensino superior que possuem o certificado de entidade beneficente de assistência social. Segundo dados do Ministério da Educação ${ }^{3}$, essas instituições deverão beneficiar, anualmente, com bolsas de estudos, em torno de 100 mil estudantes.

Esses fatos demonstram a importância das IESCEBAS para a nação, primeiro pela atividade que desenvolvem e depois por atenderem pessoas sem condições de acesso ao nível superior, ressaltando é claro que os recursos são da própria sociedade. Daí a importância de se verificar como estão sendo aplicados esses recursos.

FALCÃO ${ }^{4}$ acredita que a principal dificuldade das organizações sem fins lucrativos sejam os seus dirigentes. Segundo ele:

"Estes dirigentes são técnicos altamente capacitados e bem intencionados, mas sem nenhum conhecimento ou capacitação gerencial. Existem muitas instituições honestas que realizam um ótimo trabalho, que deverão fechar

\footnotetext{
${ }^{2}$ Fonte CNAS - www.previdenciasocial.gov.br/14.asp acesso em 19.08.2002

${ }^{3}$ Fonte MEC - www.mec.gov.br/sesu/pergres.shtm acesso em 19.08.2002

${ }^{4}$ FALCÃO, Ricardo. Entrevista disponível em $<$ http://www.dearo.com/html/paginas/entrevista com ricardo falcao.asp $>$ acesso em 22.05.2002
} 
suas portas por incompetência gerencial”.

A afirmação acima demonstra a preocupação do autor com relação à gestão das instituições sem fins lucrativos, não por má fé dos dirigentes, mas sim por falta de conhecimento e capacitação gerencial.

As IESCEBAS, assim como as demais instituições sem finalidades de lucros, necessitam como todas as organizações de informações para bem gerir os seus recursos.

Falando sobre os sistemas de informações contábeis dessas instituições, OLAK (2000:08) afirma:

"Mesmo desempenhando funções sociais de extrema importância, essas entidades têm recebido pouca atenção de estudiosos, no sentido de fomentar a aplicação de novas técnicas contábeis e gerenciais, amplamente discutidas no contexto empresarial. Como conseqüência, os sistemas de informações contábeis e gerenciais atualmente utilizados por essas entidades podem não satisfazer plenamente às necessidades dos gestores no processo de tomada de decisões".

No Brasil, muito pouco se tem estudado sobre a Contabilidade dessas instituições. Alguns pesquisadores têm escrito artigos sobre a Contabilidade das instituições sem fins lucrativos, sem contudo, enfocar os aspectos particulares das IESCEBAS. Desconhece-se, entretanto, qualquer pesquisa sobre as entidades objeto deste estudo.

Em face das considerações apresentadas, justificamos a importância deste estudo, no sentido de contribuir para o aperfeiçoamento das informações contábeis das IESCEBAS, tanto para fins de gestão, quanto para subsidiar os usuários externos (governo e sociedade). 


\subsection{Estrutura do Trabalho}

Além da Introdução constante no primeiro capítulo, este trabalho está estruturado da seguinte forma:

No capítulo segundo, busca-se identificar as principais características das IESCEBAS, tais como: conceitos, legislação aplicável, registro no Conselho Nacional de Assistência Social, obrigações fiscais e benefícios usufruídos.

No capítulo terceiro, realiza-se a análise dos resultados da pesquisa empírica, com o intuito de verificar os problemas abordados.

No capítulo quarto, apresenta-se modelo de apuração e evidenciação dos impactos patrimoniais e econômicos gerados pelo certificado, utilizando-se dos conceitos de Custos, Receitas, Ativo, Passivo e Custo de Oportunidade.

No quinto capítulo, realizam-se análises das demonstrações contábeis da UCDB e PUC/Rio, aplicando o modelo proposto para apuração e constatação da sua utilidade.

Por fim, apresenta-se as conclusões da pesquisa. 


\section{CAPÍTULO 2 - CARACTERIZAÇÃO DAS INSTITUIÇÕES DE ENSINO SUPERIOR COM CERTIFICADO DE ENTIDADE BENEFICENTE DE ASSISTÊNCIA SOCIAL}

O objetivo deste capítulo é fornecer uma visão sobre o histórico da educação superior no Brasil, suas finalidades, forma jurídica e os benefícios fiscais destas instituições, bem como apresentar uma definição do que é uma IESCEBAS.

Em termos metodológicos, busca-se, caracterizar as instituições objeto desse estudo, formando um referencial importante para a identificação e observação dos principais eventos econômicos relacionados com o CEBAS.

\subsection{Breve história da educação superior no Brasil}

A história do ensino superior no Brasil é recente. Somente com a independência, em 1822, é que o país efetivamente começa a ter um projeto educacional. Os primeiros estabelecimentos de ensino superior surgiram no início do Império, como por exemplo: Escola da Marinha e Academia Militar, Escolas de Medicina (Rio de Janeiro e Bahia), Cursos de Ciências Jurídicas e Sociais (São Paulo e Olinda) e Academia Imperial de Belas-Artes, além dos seminários e colégios religiosos. Somente a partir de 1910 é que começaram a estabelecerem-se as 
primeiras universidades brasileiras (Manaus, São Paulo, Rio de Janeiro e Curitiba), porém seu funcionamento durou pouco tempo, em virtude de uma lei que, em 1915, extinguiu as universidades.

Com a Proclamação da República, em 1889, o país apresenta sinais de uma reestruturação, pelo menos administrativa, ocorrendo paralelamente uma reforma no ensino. Surgem, em 1890, o Ministério da Instrução Pública e os Correios e Telégrafos, o primeiro dedicado à educação no país.

Em 1920, é criada a primeira instituição universitária pública do Brasil, a Universidade do Rio de Janeiro, hoje UFRJ. Sete anos após a criação da nossa primeira universidade pública, surge a Universidade de Minas Gerais.

Com a Revolução de 1930, foi criado o Ministério dos Negócios da Educação e Saúde Pública e, em 1931, o Conselho Nacional de Educação. O ensino superior sofre reformas, fazendo com que surgissem novas universidades.

Importantes universidades foram criadas: Universidade de São Paulo (1934), Universidade do Distrito Federal (1935) e Universidade de Porto Alegre (1936).

Com o Estado Novo, em 1937, surgem novas reformas educacionais, sendo criado, em 1938, o Instituto Nacional de Estudos Pedagógicos - INEP, cuja finalidade era funcionar como centro de estudos das questões educacionais e suas pesquisas deveriam ajudar o Ministério da Educação e Saúde na formulação das políticas públicas para a educação. Em 1972, o INEP passa a ser um órgão de assessoramento do Ministério, tendo sido transformado em um órgão autônomo, passando a ser o Instituto Nacional de Estudos e Pesquisas Educacionais que, em 1997, é transformado em autarquia federal e seu objetivo principal a avaliação e 
informação educacional.

Com a chegada do Estado Novo, em 1945, começa um processo de massificação do ensino superior com um aumento crescente no número de universidades no país.

Em 1953, o Ministério da Educação e Saúde é separado em: Ministério da Educação e Cultura (MEC) e Ministério da Saúde. Em 1961, entra em vigor a primeira Lei de Diretrizes e Bases da Educação - LDB.

Em 1968, é promulgada a Lei da Reforma Universitária, que fixou as normas de organização e funcionamento do ensino superior, destacando como atividades universitárias o ensino, extensão e pesquisa.

A primeira instituição particular de ensino superior no Brasil surgiu em 1940, com o objetivo de atender à demanda da população e ajudar o Estado em seu fim institucional. Na década de 1970, as instituições privadas superam as instituições públicas em número de vagas oferecidas.

Após alguns anos de debate, em 1996 é aprovada a nova LDB, que definiu o sistema federal de ensino da seguinte forma:

"Art. 16. O sistema federal de ensino compreende:

I - as instituições de ensino mantidas pela União;

II - as instituições de educação superior criadas e mantidas pela iniciativa privada;

III - os órgãos federais de educação”.

Em julho de 2001, o governo, através do Decreto $n^{\circ} 3.860$, estabeleceu as formas de organização das instituições de ensino superior. 
“Art. $7^{\circ}$. Quanto à sua organização acadêmica, as instituições de ensino superior do Sistema Federal de Ensino classificam-se em:

I - universidades;

II - centros universitários; e

III - faculdades integradas, faculdades, institutos ou escolas superiores.

Art. $8^{\circ}$. As universidades caracterizam-se pela oferta regular de atividades de ensino, de pesquisa e de extensão, atendendo ao que dispõem os artigos 52,53 e 54 da Lei ${ }^{\circ}$ 9.394, de 20 de dezembro de 1996.

Art. $11^{\circ}$. Os centros universitários são instituições de ensino superior pluricurriculares, que se caracterizam pela excelência do ensino oferecido, comprovada pelo desempenho de seus cursos nas avaliações coordenadas pelo Ministério da Educação, pela qualificação do seu corpo docente e pelas condições de trabalho acadêmicos oferecidas à comunidade escolar.

Art. $12^{\circ}$. Faculdades integradas são instituições com propostas curriculares em mais de uma área de conhecimento, organizadas para atuar com regimento comum e comando unificado.

Art. $14^{\circ}$. Os institutos superiores de educação criados na forma do Decreto $\mathrm{n}^{\circ} 3.276$, de 6 de dezembro de 1999, deverão definir planos de desenvolvimento institucional.

Parágrafo Único. Os institutos de que trata o caput, poderão ser organizados como unidades acadêmicas de instituições de ensino superior já credenciadas, devendo neste caso definir planos de desenvolvimento acadêmico.” 
Surgiu, a partir de 1997, a figura dos Centros Universitários, instituições de ensino superior que estão entre as universidades e as faculdades. O Decreto $\mathrm{n}^{\mathrm{o}} 3.860$ estabeleceu as formas de organização, bem como definiu qual seria a classificação das instituições de ensino superior.

\subsection{Finalidades da Educação Superior}

O setor educacional no Brasil tem sofrido grandes e profundas alterações nos últimos anos. O Governo Federal tem editado Leis que regulam e direcionam o ensino no país, no sentido de que haja uma evolução qualitativa da oferta do ensino no Brasil. Para o ex-ministro da Educação, Paulo Renato de Souza5, "nunca houve como hoje, no ensino superior brasileiro, tanta supervisão, tanta avaliação e tanta transparência na autorização, reconhecimento e recredenciamento de cursos e

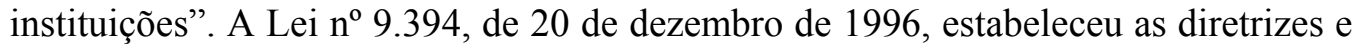
bases da educação nacional, definindo, dessa forma, os critérios e mecanismos de funcionamento do ensino no país.

O Art. 43 da referida Lei estabelece quais as finalidades da Educação Superior:

"I - estimular a criação cultural e o desenvolvimento do espírito científico e do pensamento reflexivo;

II - formar diplomados nas diferentes áreas de conhecimento, aptos para a inserção em setores profissionais e para a participação no desenvolvimento da

\footnotetext{
5 Souza, Paulo Renato. Enfrentar e vencer desafios. 2000. Disponível em $<$ http//www.mec.gov.br/home/ftd/sesu/enfr.doc $>$ acesso em 27.06.2002.
} 
sociedade brasileira, e colaborar na sua formação contínua;

III - incentivar o trabalho de pesquisa e investigação científica, visando o desenvolvimento da ciência e da tecnologia e da criação e difusão da cultura, e, desse modo, desenvolver o entendimento do homem e do meio em que vive;

IV - promover a divulgação de conhecimentos culturais, científicos e técnicos que constituem patrimônio da humanidade e comunicar o saber através do ensino, de publicações ou de outras formas de comunicação;

$\mathrm{V}$ - suscitar o desejo permanente de aperfeiçoamento cultural e profissional e possibilitar a correspondente concretização, integrando os conhecimentos que vão sendo adquiridos numa estrutura intelectual sistematizadora do conhecimento de cada geração;

VI - estimular o conhecimento dos problemas do mundo presente, em particular os nacionais e regionais, prestar serviços especializados à comunidade e estabelecer com esta uma relação de reciprocidade;

VII - promover a extensão, aberta à participação da população, visando à difusão das conquistas e benefícios resultantes da criação cultural e da pesquisa científica e tecnológica geradas na instituição."

Atender às finalidades previstas em Lei e às necessidades do mercado, torna-se o grande desafio das instituições de ensino superior. As responsabilidades das instituições de ensino superior, diante do exposto, são enormes, exigindo-lhes elevada competência pedagógica e administrativa, na busca do cumprimento dos seus objetivos. Essas finalidades, além de serem fiscalizadas pelo Ministério da 
Educação, através dos seus instrumentos de avaliação, são verificadas também pela sociedade, que, através do mercado, avaliam a qualidade do ensino que cada instituição está oferecendo.

\subsection{Forma Jurídica das Instituições de Ensino Superior no Brasil}

O art. 19 da Lei $\mathrm{n}^{\circ} 9.394^{6}$ define a classificação das instituições de ensino, dividindo-as nas seguintes categorias administrativas:

"I - públicas, assim entendidas as criadas ou incorporadas, mantidas e administradas pelo Poder Público;

II - privadas, assim entendidas as mantidas e administradas por pessoas físicas ou jurídicas de direito privado”.

As instituições privadas, de acordo com o art. 20 da mesma Lei se enquadram nas seguintes categorias:

"I - particulares em sentido estrito, assim entendidas as que são instituídas e mantidas por uma ou mais pessoas físicas ou jurídicas de direito privado que não apresentem as características dos incisos abaixo;

\footnotetext{
${ }^{6}$ Lei de Diretrizes e Bases da Educação Nacional
} 
II - comunitárias, assim entendidas as que são instituídas por grupos de pessoas físicas ou por uma ou mais pessoas jurídicas, inclusive cooperativas de professores e alunos que incluam na sua entidade mantenedora representantes da comunidade;

III - confessionais, assim entendidas as que são instituídas por grupos de pessoas físicas ou por uma ou mais pessoas jurídicas que atendem a orientação confessional e ideologia específicas e ao disposto no inciso anterior;

IV - filantrópicas na forma da lei”.

Já o art. $1^{\circ}$ do Decreto n ${ }^{\circ} 2.306$ de 19 de agosto de 1997, que regulamentou o Sistema Federal de Ensino, estabelece:

\begin{abstract}
"As pessoas jurídicas de direito privado, mantenedoras de instituições de ensino superior, previstas no inciso II, do art. 19, da Lei $n^{\circ} 9.394$, de 20 de dezembro de 1996, poderão assumir qualquer das formas admitidas em direito, de natureza civil ou comercial e, quando constituídas como fundações, serão regidas pelo disposto no art. 24 do Código Civil Brasileiro".
\end{abstract}

Com base na legislação apresentada, verifica-se a existência de várias

formas jurídicas estabelecidas em lei, que poderão ser adotadas pelas instituições. Entretanto, nosso objeto de estudo são as instituições prescritas nos Inciso II, III e IV do Art. 20 da Lei $n^{\circ}$ 9.394, possuidoras do Certificado de Entidade de Fins Filantrópicos. 


\subsection{Gestão do Ensino Superior}

O mundo atual, em função das constantes evoluções, não permite que as decisões sejam lentas, exigindo das organizações que ainda adotam este tipo de procedimento, evoluções em suas formas de tomada de decisão. Estas instituições, assim como as demais organizações, estão em constante interação com o ambiente onde estão inseridas, sofrendo, dessa forma, influências no cotidiano das suas atividades. Necessária se faz uma contínua adaptação e flexibilidade diante das situações apresentadas pelo ambiente, sob pena de descontinuidade da organização.

Para KOTLER \& FOX (1994:128),

"Um importante exercicio para administradores e outros gerentes de uma instituição educacional é identificar periodicamente as grandes ameaças e oportunidades que ela enfrenta em cada uma de suas unidades (escolas ou faculdades, departamentos, filiais e assim por diante). Isto deve ser feito como parte da preparação dos planos anuais e a longo prazo. Cada ameaça e oportunidade recebe um número que é depois avaliado conforme seu provável nível de efeito e ocorrência".

Após identificadas as ameaças e oportunidades, os administradores, gerentes ou gestores devem verificar quais os impactos que poderá sofrer a organização, devendo ser verificados os pontos fracos e fortes, que poderão impactar diretamente na continuidade da organização.

A figura 1 mostra algumas entidades e variáveis que influenciam o ambiente das instituições de ensino superior com certificado de entidade de fins filantrópicos: 


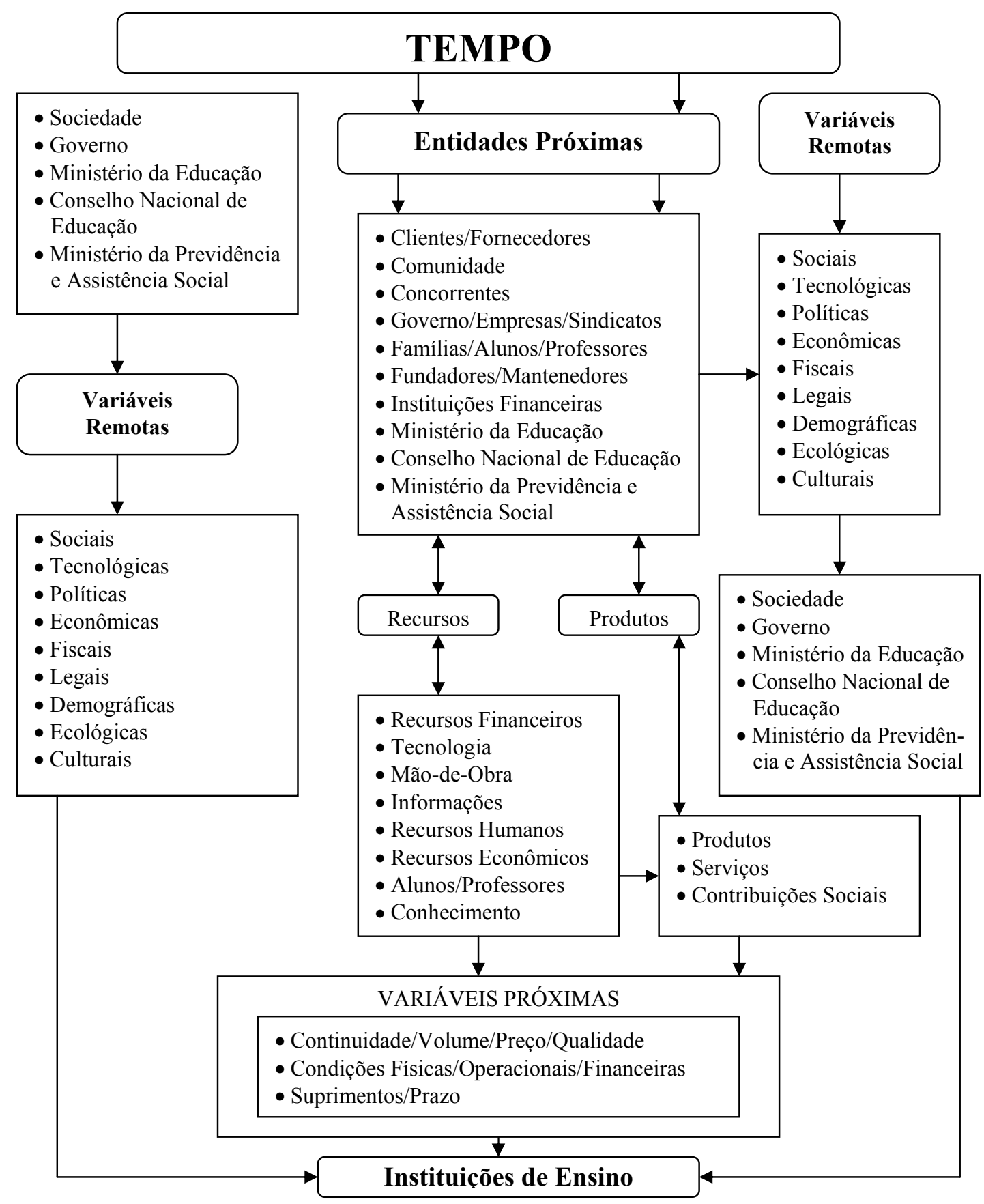

Figura 1 - $\mathrm{O}$ ambiente e as instituições de ensino superior com certificado de filantropia 7

${ }^{7}$ Adaptado de BENEDICTO (1997:22) 
As entidades próximas representam o segmento em que atuam e competem. As variáveis remotas são definidas por entidades que não se relacionam diretamente com as mesmas, entretanto possuem autoridade suficiente para definir variáveis. As variáveis próximas são determinadas pela atuação da empresa, através da sua eficácia na administração dos negócios com o objetivo de otimizar seu resultado.

As entidades e variáveis, sendo agentes externos à organização, agem de diferentes maneiras na sua administração seja por suas expectativas ou problemas, cada uma buscando satisfazer às suas necessidades, sendo necessário, por parte dos gestores, um esforço bem maior no sentido de descobrir quais são estas necessidades, expectativas e problemas e como podem influenciar a organização.

Para BENEDICTO (1997:23), “As instituições de ensino, como organizações sociais, buscam os insumos e recursos num mercado fornecedor, transformam esses insumos e recursos em produtos, serviços e contribuições sociais e os devolvem para um mercado comprador, ou seja, a sociedade".

Para tanto, essas instituições devem estar preparadas, no sentido de buscar os melhores recursos e fornecer à sociedade um excelente produto que atenda às suas expectativas.

Cada vez mais, assistimos às inúmeras mudanças que ocorrem no mundo e com uma velocidade cada vez maior. Vivemos uma nova revolução, não das armas, das indústrias, mas da era informação. Esta nova era exige que as organizações passem a valorizar e investir cada vez mais na capacidade de captar e transformar informações em algo que agregue valor ao seu negócio no menor espaço de tempo.

Este novo cenário aumenta a competitividade entre as nações, passando a exigir um padrão educacional mais elevado, compatível com as novas exigências do 
mercado.

De acordo com TACHIZAWA (2002:85), “...infere-se que o ambiente externo ou mercado é um fator contingencial que estabelece parâmetros, limites, propostas e desafios que têm que ser interpretados e tornados significativos, de acordo com a escala de valores e crenças da organização".

As IESCEBAS, não alheias a este processo, devem estar preparadas, no sentido de atender à demanda da sociedade, sob pena de serem absorvidas pela concorrência. Com o aumento crescente das exigências dos mercados por mão-deobra mais qualificada, atualizada e especializada, surgem novas oportunidades para essas instituições, ao mesmo tempo em que aumenta a competitividade.

Sobre a competitividade da empresa, PEREIRA in CATELI (2001:45) a caracteriza como "o grau em que ela é capaz de concorrer com as condições e alternativas oferecidas pelo mercado”.

Por essas instituições pertencerem ao terceiro setor e não possuírem finalidade lucrativa, fica a impressão de que não possuem concorrentes e também concorrência.

Sobre este assunto, ARANTES apud ARAÚJO (2001:35) ressalta que tais organizações se submetem à "concorrência do programa similar oferecido por outra entidade, que também disputa 'parcerias' e nichos em 'mercados inovadores"”.

Para TACHIZAWA (2002:84): “A organização é guiada por seus próprios critérios e feedback internos, mas é, em última instância, conduzida pelo feedback de seu mercado e pelos efeitos que gera no meio ambiente. A concorrência também estará recorrendo aos recursos e fornecendo seus produtos e serviços ao mesmo mercado". 
Falando, também, sobre concorrência, PEREIRA in CATELLI (2001:45)

afirma que a concorrência existe de forma direta, onde a empresa concorre com outras entidades que oferecem o mesmo produto com condições diferenciadas, e também concorre na aquisição dos recursos necessários ao desenvolvimento de suas atividades.

As IESCEBAS sofrem a concorrência direta de todos os tipos de instituições de ensino superior, necessitando dessa forma demonstrar competência não só acadêmica como também na gestão.

Quanto a essa questão, FREITAS (2002:40) enfatiza, "Diante dos desafios dos novos tempos, cada vez mais há consciência de que as instituições terão de desenvolver não apenas competência acadêmica, mas uma capacidade de gestão mais profissional".

Também a respeito dessa questão, GIBSON, IVANCEVICH e DONNELY citando A. K. Rice, autor de The Modern University (1988:80), asseguram:

"A sobrevivência de uma universidade vai depender de sua capacidade de conseguir dos contribuintes recursos monetários em quantidade suficiente para pagar o salário do corpo docente, de seu staff e para cobrir os demais custos. Se o produto da universidade for rejeitado pelo ambiente mais amplo, no qual ela se insere, de modo que os estudantes venham a se matricular em outros locais e os contribuintes a dar apoio a outros empreendimentos públicos, ou se a universidade gastar demais com os recursos, comparados ao produto, ela deixará de existir. Como a empresa, a universidade deverá fornecer o produto certo, no preço certo, se quiser sobreviver".

Inúmeros são os problemas enfrentados no cotidiano das instituições de

ensino, exigindo alto grau de competência por parte dos gestores, bem como a profissionalização da gestão, no sentido de oferecer um produto com qualidade e ao 
preço que a comunidade esteja disposta a pagar. É preciso ter clareza de que é o mercado que regula os preços e que as instituições devem se adaptar a ele.

BENEDICTO (1997:38) afirma que:

"Hoje em dia, o ambiente nem sempre é favorável às instituições de ensino. A imagem que predomina é a de ineficiência administrativa, desperdício de recursos, baixa produtividade acadêmica, salários incompatíveis com a função do educador, qualidade questionável, abuso de preços por parte das escolas particulares e greves".

Enfrentar os inúmeros problemas com competência e romper com as barreiras existentes, quebrar paradigmas e manter-se no mercado, são os grandes desafios dessas instituições.

MENDES (2002:42) evidencia três pontos básicos para o gestor que busca um gerenciamento administrativo dinâmico, a saber: "respostas rápidas, serviços eficientes e desburocratização dos processos. Todos esses, claro, sob o alicerce de dados e números eficientes para as tomadas de decisão de cunho empresarial”.

O problema, que ocorre muitas vezes, é que essas instituições não são tratadas pela sua administração como uma empresa, ficando, dessa forma, vulneráveis a todos os tipos de problemas e comprometendo a continuidade da organização.

WELSCH (1983:20) afirma:

“(...) as responsabilidades de planejamento, coordenação e controle da administração são fundamentalmente idênticas em atividades empresariais e não-empresariais ${ }^{8}$ (sic); o processo de

${ }^{8}$ Termo utilizado pelo autor para tratar das Entidades Sem Fins Lucrativos. 
administração geralmente assume uma forma comum, qualquer que seja o tipo do empreendimento".

SIENA \& BALDRIDGE apud SCHRADER (1998:33) afirmam que:

\begin{abstract}
"As universidades possuem uma arquitetura social burocrático-legal que contrasta com a forma como a maioria das organizações contemporâneas estão estruturadas. Embora identifiquem uma estrutura burocráticoadministrativa, semelhante às outras organizações, o funcionamento, em termos de prática administrativa, não corresponde em grau de desempenho aos elementos da organização burocrática ideal: formalismo, impessoalidade e profissionalismo".
\end{abstract}

As IESCEBAS possuem particularidades que as diferenciam das outras organizações, entretanto, as formas de administração utilizadas se assemelham às das outras organizações.

Essas instituições devem ter um modelo de administração que lhe permita adotar um conjunto de ações visando a atingir seus objetivos, bem como a satisfação da comunidade. Para que essas ações sejam eficazes, devem estar baseadas em decisões corretas. Para que isto seja possível, as instituições deverão possuir informações, conhecimento da realidade e rapidez nas decisões.

De acordo com DRUCKER (1997:89), “Os executivos, quer estejam em uma instituição sem fins lucrativos ou em uma empresa, dedicam pouco tempo à tomada de decisões. Muito mais tempo é gasto com reuniões, com pessoas ou em tentativas de obtenção de um pouco de informações”.

Para o autor, é através das informações que se define o sucesso ou fracasso das organizações.

Para PELEIAS (2002:15), “A informação é a base e o resultado da ação 
executiva. A partir desta constatação, é preciso empreender esforços para suprir os gestores com ferramentas de informática que permitam o planejamento, o registro e o controle das decisões tomadas em cada fase do processo de gestão".

\subsection{O que são Instituições de Ensino Superior com Certificado de Entidade Beneficente de Assistência Social}

Definir IESCEBAS somente como uma instituição de ensino superior sem finalidades lucrativas e portadoras do Certificado de Entidade Beneficente de Assistência Social, seria uma definição incompleta. Por isso, faremos uma reflexão sobre algumas características dessas entidades.

Essas instituições, por não possuírem finalidades lucrativas, estão classificadas como Terceiro Setor.

Para FERNANDES ${ }^{9}$, o terceiro setor é:

"composto de organizações sem fins lucrativos, criadas e mantidas pela ênfase na participação voluntária, num âmbito não governamental, dando continuidade às práticas tradicionais de caridade, da filantropia e do mecenato e expandindo o seu sentido para outros domínios, graças, sobretudo, à incorporação do conceito da cidadania e de suas múltiplas manifestações na sociedade civil”.'(grifo nosso)

As IESCEBAS não se caracterizam pela participação voluntária, pois suas atividades são desenvolvidas por funcionários remunerados pela prestação dos serviços, sendo possível, dessa forma, a contratação e remuneração de funcionários para desempenharem as funções necessárias para o desenvolvimento das atividades. Outrossim, em face dos serviços que prestam, exigem a qualificação dos

9 FERNANDES, Rubens César. O que é Terceiro Setor? 1996. Disponível em $<\mathrm{http} / /$ www.rits.org.br/idac.rits.org.br/idac_em3.html> acesso em 17.10.2002. 
colaboradores, em função não só das exigências do Ministério da Educação, bem como da sociedade.

HUDSON (1999:08) define que as instituições do terceiro setor:

• "têm basicamente um objetivo social em vez de procurarem gerar lucro;

• são independentes do Estado porque são administradas por um grupo independente de pessoas e não fazem parte de um departamento de governo ou de autoridades locais ou de saúde;

- reinvestem todo o seu saldo financeiro nos serviços que oferecem ou na própria organização".

Entende-se, que, nessa definição, estão incluídas as entidades objeto deste estudo, visto possuírem as mesmas características supracitadas.

Segundo BRAVA apud ARAÚJO (2002:03),

"Para o Banco Mundial e outras instituições multilaterais, o Terceiro Setor, tendo à frente as ONGs, (sic), tem um importante papel executor de políticas sociais, articulado e complementar à ação do Estado.(...) estas instituições sem fins lucrativos (...) são eficientes, baratas, não desperdiçam recursos com a burocracia, não são corruptas, apresentam resultados muito mais significativos que a ação do Estado”. 
FREEMAN \& SHOULDERS apud OLAK(1996:23) apresentam algumas características que são peculiares às entidades sem fins lucrativos:

“a) quanto ao lucro (profit): o lucro não é a razão de ser dessas entidades;

b) quanto à propriedade (ownership): pertence à comunidade. Não é normalmente caracterizada pela divisibilidade em parte proporcionais, que podem ser vendidas ou permutadas;

c) quanto às fontes de recursos (resourses): as contribuições com recursos financeiros não dão direito ao doador de participação proporcional nos bens ou serviços da organização;

d) quanto às decisões políticas e operacionais (policy \& operating decisions): as maiores decisões políticas e algumas decisões operacionais são tomadas por consenso de voto, via assembléia geral, por membros de diversos segmentos da sociedade direta ou indiretamente eleitos".

Uma característica marcante dessas entidades são as suas finalidades sociais. Sobre esta questão, DRUCKER (1997:03) afirma que: “a organização sem fins lucrativos existe para provocar mudanças nos indivíduos e na sociedade". Portanto, essas entidades caracterizam-se por serem um agente transformador da sociedade, atuando diretamente na vida dos indivíduos, provocando, dessa forma, mudanças comportamentais, educacionais e da saúde.

Sobre as instituições de ensino superior sem finalidades lucrativas, também podemos evidenciar que o seu produto final é a transformação de pessoas, contribuindo, desse modo, através do seu produto, para a mudança da sociedade como um todo. 
Para BENEDICTO (1997:20):

\begin{abstract}
"As instituições de ensino - quer particulares, quer públicas, com ou sem fins lucrativos - são organizações constituídas para oferecer benefícios à sociedade. Esses beneficios são de natureza social, cultural, econômica, educativa, tecnológica e moral. Sua existência só tem sentido quando realmente estão contribuindo para o desenvolvimento da comunidade".
\end{abstract}

A essas características podemos acrescentar que, diferentemente da maioria das entidades sem finalidades lucrativas, estas entidades sobrevivem com recursos oriundos de mensalidades provenientes da prestação de serviços educacionais e também de subvenções e convênios firmados tanto com a iniciativa privada como com órgãos governamentais.

O lucro, segundo autores anteriormente citados, não é objetivo dessas entidades, entretanto, necessário para a manutenção do patrimônio e para assegurar a continuidade e o cumprimento da missão da instituição.

Adiciona-se a essas características o Certificado de Entidade Beneficente de Assistência Social, expedido pelo CNAS.

O Decreto $\mathrm{n}^{\circ} 2.536$, de 6 de abril de 1998, estabelece os critérios para a concessão do Certificado:

"Art. $2^{\circ}$ - Considera-se entidade beneficente de assistência social, para fins deste Decreto, a pessoa jurídica de direito privado, sem fins lucrativos, que atue no sentido de:

I - proteger a família, a maternidade, a infância, a adolescência e a velhice;

II - amparar crianças e adolescentes carentes;

III - promover ações de prevenção, habilitação e reabilitação de pessoas 
portadoras de deficiências;

IV - promover, gratuitamente, assistência educacional ou de saúde; $\mathrm{V}$ - promover a integração ao mercado de trabalho.

Art. $3^{\circ 10}$ - Faz jus ao Certificado de Entidade Beneficente de Assistência Social, a entidade beneficente de assistência social que demonstre, cumulativamente:

I - estar legalmente constituída no País e em efetivo funcionamento, nos três anos anteriores a solicitação do Certificado;

II - estar previamente inscrita no Conselho Municipal de Assistência Social do município de sua sede se houver, ou no Conselho Estadual de Assistência Social, ou Conselho de Assistência Social do Distrito Federal;

III - estar previamente registrada no CNAS;

IV - aplicar suas rendas, seus recursos e eventual resultado operacional integralmente no território nacional e manutenção e no desenvolvimento de seus objetivos institucionais;

${ }^{10}$ Alterado pelo Decreto no 4.499, de 4 de Dezembro de 2002 
V - aplicar as subvenções e doações recebidas nas finalidades a que estejam vinculadas;

VI - aplicar anualmente, em gratuidade, pelo menos vinte por cento da receita bruta proveniente da venda de serviços, acrescida da receita decorrente de aplicações financeira, de locação de bens, de venda de bens não integrantes do ativo imobilizado e de doações particulares, cujo montante nunca será inferior à isenção de contribuições sociais usufruídas;

VII - não distribuir resultados, dividendos, bonificações, participações ou parcelas do seu patrimônio, sob nenhuma forma ou pretexto;

VIII - não perceberem seus diretores, conselheiros, sócios, instituidores, benfeitores ou equivalente remuneração, vantagens ou benefícios, direta ou indiretamente, por qualquer forma ou título, em razão das competências, funções ou atividades que lhes sejam atribuídas pelos respectivos atos constitutivos;

IX - destinar, em seus atos constitutivos, em caso de dissolução ou extinção, o eventual patrimônio remanescente a entidades congêneres registradas no CNAS ou a entidade pública;

X - não constituir patrimônio de indivíduo ou de sociedade sem caráter beneficente de assistência social;

XI - seja declarada de utilidade pública federal.”

Cabe-nos, agora, diante do que foi apresentado e considerando os objetivos deste trabalho, delinearmos o conceito de IESCEBAS.

\section{Quadro nº 01 - Conceito de IESCEBAS}


Instituições de Ensino Superior com Certificado de Entidade Beneficente de Assistência Social são instituições registradas no CNAS, que apliquem, anualmente, em gratuidades, pelo menos $20 \%$ (vinte por cento) da sua receita bruta total; que promovam a assistência educacional em nível superior, visando à preparação do indivíduo para o mercado de trabalho, provocando, dessa forma, mudanças na sociedade e cujo patrimônio é constituído, mantido e ampliado, a partir de mensalidades, subvenções, doações e convênios com entidades públicas e privadas, não podendo, de forma alguma, seus diretores, conselheiros, sócios, instituidores, benfeitores ou equivalente receber qualquer remuneração, por qualquer forma ou título, em razão das competências, funções ou atividades que lhes sejam atribuídas pelos respectivos atos constitutivos.

\subsection{Benefícios Fiscais das IESCEBAS}

Iniciaremos nossas considerações sobre os Benefícios estendidos as IESCEBAS, com um artigo da CF/88.

“Art. 150. Sem prejuízo de outras garantias asseguradas ao contribuinte, é vedado à União, aos Estados, ao Distrito Federal e aos Municípios:

(...) 
VI - instituir impostos sobre:

c) patrimônio, renda ou serviços dos partidos políticos, inclusive suas fundações, das entidades sindicais dos trabalhadores, das instituições de educação e de assistência social, sem fins lucrativos, atendidos os requisitos da lei;

\title{
$(\ldots)$
}

$\S 4^{\circ}$ As vedações expressas no inciso IV, alíneas b e c, compreendem somente o patrimônio, a renda e os serviços, relacionados com as finalidades essenciais das entidades nelas mencionadas."

O exame do texto constitucional mostra que estamos diante de uma imunidade condicionada, pois para que a entidade goze dos benefícios, é necessário que se enquadre nos requisitos estabelecidos em lei.

CHIESA (2000:156) afirma que:

\begin{abstract}
"as imunidades condicionadas são aquelas veiculadas por meio de normas sujeitas à regulamentação infraconstitucional para sua completitude normativa para efeitos de fruição, a ser viabilizada pelo processo de integração. Vale dizer, o desfrute dos benefícios da imunidade estão condicionados ao cumprimento de determinados requisitos estabelecidos em leis infraconstitucionais".
\end{abstract}

Segundo o mesmo autor, não se trata de uma complementação à norma imunizante, mas requisitos formais a serem observados pelos favorecidos para gozo dos benefícios proporcionados pela imunidade.

Para que as instituições de educação gozem dos benefícios estabelecidos no texto constitucional, é preciso, conforme o Art. 150, VI, “c” atender, aos requisitos estabelecidos em lei.

Esses requisitos são para CHIESA (2000:178) estabelecidos no Código 
Tributário Nacional, afirmando:

"O art. 14 do Código Tributário Nacional, é o comando que estabelece os requisitos formais a serem preenchidos pelos interessados em usufruir dos benefícios proporcionados por uma das hipóteses de imunidades condicionadas, a prevista no art. 150, VI, "c", e também do $\S 7^{\circ}$, do art. 195, ambos da Constituição Federal”.

O Capítulo II do Código Tributário Nacional, que trata das limitações da competência tributária, estabelece:

“Art. 9. É vedado à União, aos Estados, ao Distrito Federal e aos Municípios:

\section{$(\ldots)$}

IV - cobrar impostos sobre:

(...)

c) o patrimônio, a renda ou serviços de partidos políticos e de instituições de educação ou de assistência social, observados os requisitos fixados na Seção II deste Capítulo;"

Esses requisitos, conforme CHIESA, estão descritos no Art. 14 do Código Tributário Nacional, que estabelece:

"Art. $14^{\circ}$. O disposto na alínea $\mathrm{c}$ do inciso IV do art. $9^{\circ}$ é subordinado à observância dos seguintes requisitos pelas entidades nele referidas:

I - não distribuírem qualquer parcela de seu patrimônio ou de suas rendas, a título de lucro ou participação no seu resultado;

II - aplicarem integralmente, no País, os seus recursos na manutenção dos seus objetivos institucionais; 
III - manterem escrituração de suas receitas e despesas em livros revestidos de formalidades capazes de assegurar sua exatidão".

O objetivo dos benefícios previstos no art. 150, VI, “c”, da Constituição Federal, estendidos às instituições de educação, é incentivar a criação de entidades sem fins lucrativos que desempenhem atividades de educação, contribuindo com o Estado em suas atividades fins, dentro do território brasileiro. Trata-se de um benefício com o objetivo de melhorar as condições sociais do povo brasileiro, sendo, portanto vedada a remessa de recursos para outros países.

O Art. 14 do Código Tributário Nacional estabelece o dever que as entidades têm de manter os livros necessários para registro e escrituração das suas receitas e despesas, obedecidas as formalidades necessárias para garantir sua exatidão.

Sem entrarmos no mérito das discussões jurídicas que ocorrem sobre o tema, é vedado à União, aos Estados, ao Distrito Federal e aos Municípios, pela Constituição Federal, instituir impostos sobre as entidades elencadas no Art. 150, VI, “c”, que preencherem os requisitos estabelecidos em lei. Os benefícios estendemse somente aos impostos, compreendendo:

- Imposto de Renda;

- Imposto Sobre Propriedade de Veículo Automotor - IPVA;

- Imposto Sobre a Transmissão Causa Mortis e Doação de Quaisquer Bens ou Direitos - ITCD;

- Imposto Sobre Circulação de Mercadorias e Serviços - ICMS;

- Imposto Sobre Serviços de Qualquer Natureza - ISSQN; 
- Imposto Predial Territorial Urbano - IPTU;e

- Imposto Sobre Transmissão de Bens Imóveis e de Direitos a Eles Relativos - ITBI.

O $\S 7^{0}$ do Inciso III do Art. 195 da CF/88 estabelece que: "São isentas de contribuição para a seguridade social às entidades beneficentes de assistência social que atendam às exigências estabelecidas em lei”.

As instituições de ensino superior sem finalidades lucrativas, desde que cumpridos os requisitos estabelecidos no Decreto $\mathrm{n}^{\circ} 2.536$, são consideradas entidades beneficentes de assistência social, portanto isentas das contribuições para a seguridade social de responsabilidade da empresa, sendo que os descontos efetuados dos funcionários, autônomos e empresas, devem ser recolhidos normalmente.

As contribuições para a seguridade social estão prescritas no art. 22 e 23 da Lei $\mathrm{n}^{\circ}$ 8.212:

“Art.2211. A contribuição a cargo da empresa, destinada à Seguridade Social, além do disposto no art. 23, é de:

I - 20\% (vinte por cento) sobre o total das remunerações pagas ou creditadas, a qualquer título, no decorrer do mês, aos segurados empregados, empresários, trabalhadores avulsos e autônomos que lhe prestem serviços;

II - para o financiamento da complementação das prestações por acidente do trabalho, dos seguintes percentuais, incidentes sobre o total das remunerações pagas ou creditadas, no decorrer do mês, aos segurados empregados e trabalhadores

${ }^{11}$ Contribuições devidas ao Instituto Nacional de Seguridade Social - INSS 
avulsos:

a) $1 \%$ (um por cento) para as empresas em cuja atividade preponderante o risco de acidentes do trabalho seja considerado leve;

b) $2 \%$ (dois por cento) para as empresas em cuja atividade preponderante esse risco seja considerado médio;

c) $3 \%$ (três por cento) para as empresas em cuja atividade preponderante esse risco seja considerado grave.

Art.23. As contribuições a cargo da empresa provenientes do faturamento e do lucro, destinadas à Seguridade Social, além do disposto no art. 22 são calculadas mediante a aplicação das seguintes alíquotas:

I - 2\% (dois por cento) sobre sua receita bruta, estabelecida segundo o disposto no $\S 1^{\circ}$ do art. $1^{\circ}$ do Decreto-Lei $n^{\circ} 1.940$, de 25 de maio de 1982, com a redação dada pelo art. 22, do Decreto-Lei n ${ }^{\circ}$ 2397, de 21 de dezembro de 1987, e alterações posteriores ${ }^{12}$

II $-10 \%$ (dez por cento) sobre o lucro líquido do período-base antes da provisão para o Imposto de Renda ajustado na forma do art. $2^{\circ}$ da Lei $n^{\circ} 8034$, de 12 de abril de $1990^{13} "$

No que tange às contribuições para os Programas de Integração Social e de Formação do Patrimônio do Servidor Público - PIS/PASEP, foram definidas pela Lei $\mathrm{n}^{\circ} 9.715$ de 25 de novembro de 1998 da seguinte forma:

\footnotetext{
12 Alterada para 3\% (três por cento) a alíquota da Contribuição de Financiamento para Seguridade Social - Cofins, de acordo com o Art. $8^{\circ}$ da Lei n ${ }^{\circ}$ 9.718, de 27/11/98.

13 Alterada para 9\% (nove por cento) a alíquota Contribuição Social Sobre o Lucro Líquido - CSLL de acordo com o Art. 19 da Lei n ${ }^{\circ}$ 9249/95 e $6^{\circ}$ Inciso II da MP 2158/01.
} 
“Art. 2 A contribuição para o PIS/PASEP será apurada mensalmente:

$\mathrm{I}-\ldots$

II - pelas entidades sem fins lucrativos definidas como empregadoras pela legislação trabalhista e as fundações, com base na folha de salários".

E ainda,

“Art. $8^{\circ}$ A contribuição será calculada mediante a aplicação, conforme o caso, das seguintes alíquotas:

$\mathrm{I}-\ldots$

II - um por cento sobre a folha de salários”.

Assim, a partir do que foi apresentado sobre os benefícios aplicados às IESCEBAS, apresentamos abaixo quadro resumo dos benefícios nas esferas Federal, Estadual e Municipal .

\section{Quadro nº2 - Benefícios Fiscais}

\begin{tabular}{|l|l|}
\hline ESFERAS & BENEFÍCIOS \\
\hline FEDERAL & Imposto de Renda, Cofins, CSSL e INSS \\
\hline ESTADUAL & ICMS, IPVA e ITCD \\
\hline MUNICIPAL & ISSQN, IPTU e ITBI \\
\hline
\end{tabular}

\subsection{Características das IESCEBAS}


Diante do que foi apresentado, podemos, então, apresentar algumas características fundamentais e específicas das IESCEBAS, que as diferenciam das entidades com fins lucrativos:

- as IESCEBAS objetivam provocar mudanças sociais, bem como contribuir para o desenvolvimento da sociedade;

- o patrimônio das IESCEBAS pertence à sociedade, não cabendo aos seus conselheiros, sócios, instituidores, benfeitores ou equivalentes quaisquer resultados, dividendos, bonificações, participações ou parcelas do seu patrimônio, sob nenhuma forma ou pretexto;

- deve ser reconhecida como Entidade Beneficente de Assistência Social e de Utilidade Pública Federal, registrada no CNAS e aplicar anualmente pelo menos $20 \%$ (vinte por cento) da sua receita bruta total em gratuidades;

- o lucro não é o objetivo das IESCEBAS, mas um meio necessário para assegurar a continuidade e o cumprimento de sua missão;

- os resultados devem ser aplicados integralmente no território nacional e na manutenção e desenvolvimento dos seus objetivos institucionais.

Os principais eventos econômicos gerados pelo certificado são:

- isenção das contribuições para a seguridade social; e

- a prestação de serviços gratuitos à comunidade de pelo menos $20 \%$ (vinte por cento) da receita bruta total. 


\title{
CAPÍTULO 3 - IDENTIFICAÇÃO DOS RESULTADOS DA PESQUISA
}

\author{
Após ter identificado os problemas, procurou-se selecionar formas de \\ investigação que pudessem constatar se os problemas destacados ocorrem no \\ cotidiano das IESCEBAS, objeto de estudo deste trabalho. O objetivo deste capítulo \\ é apresentar o resultado da pesquisa realizada junto às IESCEBAS do Brasil, bem \\ como, com base na legislação aplicável a essas instituições, fazer considerações \\ sobre os procedimentos contábeis adotados pelas mesmas. \\ Em termos metodológicos, objetiva-se verificar o tratamento contábil \\ aplicado pelas IESCEBAS aos resultados produzidos pelo CEBAS.
}

\subsection{Planejamento da Pesquisa e Coleta de Dados}

Uma das formas para verificar a realidade é a pesquisa de campo, que, segundo VERGARA (2000:47), “é investigação empírica realizada no local onde ocorre ou ocorreu o fenômeno ou que dispõe de elementos para explicá-lo”.

Em função das distâncias entre as instituições objeto de estudo, a forma selecionada foi a aplicação de questionários enviados pelo correio aos responsáveis técnicos pelo setor contábil. 
CRUZ NETO in MINAYO (1997:64) afirma:

"O trabalho de campo, em sintese, é fruto de um momento relacional e prático: as inquietações que nos levam ao desenvolvimento de uma pesquisa nascem no universo do cotidiano. O que atrai na produção do conhecimento é a existência do desconhecido, é o sentido da novidade e o confronto com o que nos é estranho. Essa produção, por sua vez, requer sucessivas aproximações em direção ao que se quer conhecer. E o pesquisador, ao se empenhar em gerar conhecimentos, não pode reduzir a pesquisa à denúncia, nem substituir os grupos estudados em suas tarefas político-sociais".

Foi possível, através das respostas aos questionários, conhecermos um pouco mais da realidade das IESCEBAS e, com base nas informações recebidas, elaborar propostas para a melhoria das informações contábeis dessas instituições.

\subsection{Análise dos Resultados}

Os resultados da presente pesquisa foram fruto das respostas aos questionários enviados aos responsáveis técnicos do setor contábil das IESCEBAS (Apêndice 2), através dos quais se procurou buscar elementos que pudessem demonstrar os problemas levantados, principalmente no que diz respeito ao sistema de informações contábeis dessas instituições.

O questionário elaborado foi enviado pelo correio, com envelope selado para resposta, para os Reitores e Diretores das IESCEBAS juntamente com correspondência do Reitor da Universidade Católica Dom Bosco solicitando que colaborassem com a pesquisa, dada a sua importância e pedindo ao responsável pelo setor contábil da instituição que preenchesse o questionário e o devolvesse (Apêndice 1). 
O questionário foi dividido em duas partes para melhor compreensão dos resultados, sendo que a segunda parte foi dividida em três blocos (Apêndice 3).

Na primeira parte, procurou-se conhecer o perfil da instituição, tentando identificar o tempo de existência, quantidade de alunos e de cursos e como funciona o setor contábil.

A segunda parte foi dividida em três blocos, a saber:

a) quanto à instituição: buscou-se saber há quanto tempo a instituição possui o certificado, quantidades de alunos atendidos em função do certificado, valor aplicado em beneficências e as áreas de atuação;

b) quanto aos benefícios: procurou-se constatar o conhecimento dos profissionais responsáveis com relação aos benefícios e obrigações em função do certificado; e

c) quanto às informações: tentou-se verificar como são contabilizados os fatos ocorridos em função do certificado, se o resultado entre as receitas e despesas são apurados e como são demonstradas as informações geradas.

Como a pesquisa está limitada às Instituições de Ensino Superior portadoras do Certificado de Entidades Beneficente de Assistência Social, buscamos junto ao Conselho Nacional de Assistência Social - CNAS, órgão responsável pela emissão do certificado, a relação com todas as instituições de ensino superior com certificado no Brasil. De posse da resposta do CNAS, constatamos a existência de 782 (setecentas e oitenta e duas) instituições estabelecidas no Brasil com certificado. Enviamos, então, questionários para todas as instituições constantes do cadastro do 
CNAS.

Do total dos questionários enviados retornaram 103 (cento e três), dos quais:

- 28 (vinte e oito) são de IESCEBAS;

- 23 (vinte e três) não foram encontradas ou o endereço não conferia; e

- 52 (cinqüenta e três) não são IESCEBAS.

Constatada a inconsistência no cadastro do CNAS, procuramos verificar junto ao órgão o que realmente ocorrera, sendo-nos informado que não possuem cadastro por segmento de atividade.

Deve-se registrar que a amostra trabalhada não foi estatisticamente determinada para produzir um resultado representativo do universo, podendo levar a conclusões viesadas, visto não conhecermos o total da população.

A seguir, apresentam-se os resultados da tabulação, em forma de tabelas e gráficos. As tabelas contêm as freqüências e percentagens correspondentes às opções das questões objetivas. As percentagens de questões de múltipla escolha somam mais de $100 \%$, porque os entrevistados podiam indicar mais de uma resposta.

Os resultados são apresentados na ordem das perguntas do formulário aplicado. 


\section{TABELA 01 - Instituições Pesquisadas}

\begin{tabular}{|c|c|c|c|c|c|c|c|}
\hline \multirow[b]{2}{*}{ Razão Social } & \multirow[b]{2}{*}{ Cidade } & \multirow[b]{2}{*}{ UF } & \multirow{2}{*}{$\begin{array}{c}\text { Ano } \\
\text { fundação }\end{array}$} & \multirow{2}{*}{$\begin{array}{l}\text { Quant. } \\
\text { Alunos }\end{array}$} & \multicolumn{2}{|c|}{ Cursos } & \multirow{2}{*}{$\begin{array}{c}\text { Setor } \\
\text { Contábil }\end{array}$} \\
\hline & & & & & Grad & $\begin{array}{l}\text { Pós- } \\
\text { Grad }\end{array}$ & \\
\hline $\begin{array}{l}\text { UNISUL-Universidade do } \\
\text { Sul de Santa Catarina }\end{array}$ & Tubarão & $\mathrm{SC}$ & 1964 & 23.581 & 49 & 59 & Próprio \\
\hline $\begin{array}{l}\text { Associação Evangélica de } \\
\text { Ensino }\end{array}$ & Ivoti & $\mathrm{RS}$ & 1928 & 844 & 1 & 0 & Próprio \\
\hline $\begin{array}{l}\text { Fundação Universidade de } \\
\text { Passo Fundo }\end{array}$ & Passo Fundo & $\mathrm{RS}$ & 1967 & 16.000 & 48 & 40 & Próprio \\
\hline $\begin{array}{l}\text { Fundação Instituto Nacional } \\
\text { de Telecomunicações }\end{array}$ & $\begin{array}{l}\text { Santa Rita } \\
\text { do Sapucai }\end{array}$ & MG & 1965 & 1.200 & 1 & 1 & Próprio \\
\hline $\begin{array}{l}\text { Sociedade Paranaense de } \\
\text { Cultura }\end{array}$ & Curitiba & PR & 1959 & 22.000 & 52 & 103 & Próprio \\
\hline $\begin{array}{l}\text { Sociedade Mineira de } \\
\text { Cultura }\end{array}$ & \begin{tabular}{|l|} 
Belo \\
Horizonte
\end{tabular} & MG & 1948 & 43.959 & 37 & Sim & Próprio \\
\hline $\begin{array}{l}\text { Fundação Educacional } \\
\text { Rosemar Pimentel }\end{array}$ & \begin{tabular}{|l|} 
Volta \\
Redonda
\end{tabular} & RJ & 1969 & 2.451 & 7 & 6 & Próprio \\
\hline $\begin{array}{l}\text { União Brasiliense de } \\
\text { Educação e Cultura }\end{array}$ & Taguatinga & $\mathrm{DF}$ & 1972 & 15.143 & 28 & 23 & Próprio \\
\hline Liceu Coração de Jesus & Lorena & SP & 1952 & 2.388 & 11 & 6 & Terceiriz \\
\hline $\begin{array}{l}\text { SUAM-Sociedade Unificada } \\
\text { de Ensino Superior Augusto } \\
\text { Morta }\end{array}$ & $\begin{array}{l}\text { Rio de } \\
\text { Janeiro }\end{array}$ & RJ & 1968 & 7.968 & 22 & 20 & Próprio \\
\hline $\begin{array}{l}\text { Instituto Metodista } \\
\text { Centenário }\end{array}$ & Santa Maria & $\mathrm{RS}$ & 1922 & 1.174 & 2 & 0 & Próprio \\
\hline $\begin{array}{l}\text { Faculdade Auxilei de } \\
\text { Filosofia e Letras }\end{array}$ & Lins & SP & 1957 & 1.200 & 10 & 0 & Próprio \\
\hline $\begin{array}{l}\text { Instituto Metodista de } \\
\text { Ensino Superior }\end{array}$ & $\begin{array}{l}\text { São Bern. do } \\
\text { Campo }\end{array}$ & SP & 1970 & 16.000 & 38 & 18 & Próprio \\
\hline $\begin{array}{l}\text { Instituição Adventista Sul } \\
\text { Brasil Educ. Assist.Social }\end{array}$ & Curitiba & PR & 1940 & $\begin{array}{r}30.000 \\
14\end{array}$ & 2 & 0 & Próprio \\
\hline $\begin{array}{l}\text { Sociedade Campineira de } \\
\text { Educação e Instrução }\end{array}$ & Campinas & $\mathrm{SP}$ & 1941 & 21.583 & 43 & 37 & Próprio \\
\hline $\begin{array}{l}\text { Instituto Presbiteriano } \\
\text { Cammon-Fagan }\end{array}$ & Lavras & MG & 1990 & 556 & 3 & 0 & Próprio \\
\hline $\begin{array}{l}\text { Fundação Educ.Unificada } \\
\text { Campograndense-FEUC }\end{array}$ & $\begin{array}{l}\text { Rio de } \\
\text { Janeiro }\end{array}$ & RJ & 1960 & 4.000 & 8 & 10 & Próprio \\
\hline $\begin{array}{l}\text { Instituto Filadélfia de } \\
\text { Londrina }\end{array}$ & Londrina & PR & 1945 & 2.207 & 16 & 5 & Próprio \\
\hline $\begin{array}{l}\text { ACRTS-Assoc.Cultural } \\
\text { Renovação Téc.Sorocab }\end{array}$ & Sorocaba & $\mathrm{SP}$ & 1974 & 1.104 & 4 & 1 & Próprio \\
\hline $\begin{array}{l}\text { Fund.Universitária de Saúde } \\
\text { de Taubaté }\end{array}$ & Taubaté & $\mathrm{SP}$ & 1978 & 612 & 3 & 1 & Próprio \\
\hline $\begin{array}{l}\text { IASCJ-Universidade do } \\
\text { Sagrado Coração }\end{array}$ & Bauru & SP & 1953 & 5.147 & 31 & 7 & Terceiriz \\
\hline $\begin{array}{l}\text { Sociedade Unificada de } \\
\text { Ens.Sup.Augusto Motta }\end{array}$ & \begin{tabular}{|l|} 
Rio de \\
Janeiro
\end{tabular} & RJ & 1968 & 7.968 & 22 & 20 & Próprio \\
\hline $\begin{array}{l}\text { Associação Pró-ensino Sup } \\
\text { Novo Hamburgo }\end{array}$ & \begin{tabular}{|l|} 
Novo \\
Hamburgo \\
\end{tabular} & $\mathrm{RS}$ & 1969 & 14.200 & 40 & 15 & Próprio \\
\hline
\end{tabular}

${ }^{14}$ Inclui ensino fundamental, médio e superior 


\begin{tabular}{|l|l|r|r|r|r|r|l|}
\hline $\begin{array}{l}\text { Fundação Arnaldo Vieira de } \\
\text { Carvalho }\end{array}$ & São Paulo & SP & 1962 & 596 & 3 & 5 & Próprio \\
\hline Fundação UNIPLAC & Lages & SC & 1969 & 5.000 & 17 & 10 & Próprio \\
\hline PUC do Rio de Janeiro & $\begin{array}{l}\text { Rio de } \\
\text { Janeiro }\end{array}$ & RJ & 1941 & 11.500 & 24 & 26 & Próprio \\
\hline $\begin{array}{l}\text { Ação Educacional } \\
\text { Claretiana }\end{array}$ & Batatais & SP & 1925 & 2.300 & 8 & 18 & Próprio \\
\hline $\begin{array}{l}\text { Missão Salesiana de Mato } \\
\text { Grosso }\end{array}$ & $\begin{array}{l}\text { Campo } \\
\text { Grande }\end{array}$ & MS & 1894 & 15.000 & 45 & 25 & Próprio \\
\hline
\end{tabular}

${ }^{15}$ Mantenedora da Faculdade de Ciências Médicas da Santa Casa de São Paulo 


\section{PRIMEIRA PARTE - DADOS DA INSTITUIÇÃO}

a) Ano de fundação da instituição

TABELA 02 - Tempo de Atividade

\begin{tabular}{|l|c|c|}
\hline Opções & Freq.Absoluta & Freq.Relativa \\
\hline De 10 a 20 anos & 1 & $3,57 \%$ \\
\hline De 20 a 40 anos & 13 & $46,43 \%$ \\
\hline Mais de 40 anos & 14 & $50,00 \%$ \\
\hline Total & 28 & $100,00 \%$ \\
\hline
\end{tabular}

GRÁFICO 01 - Tempo de Atividade

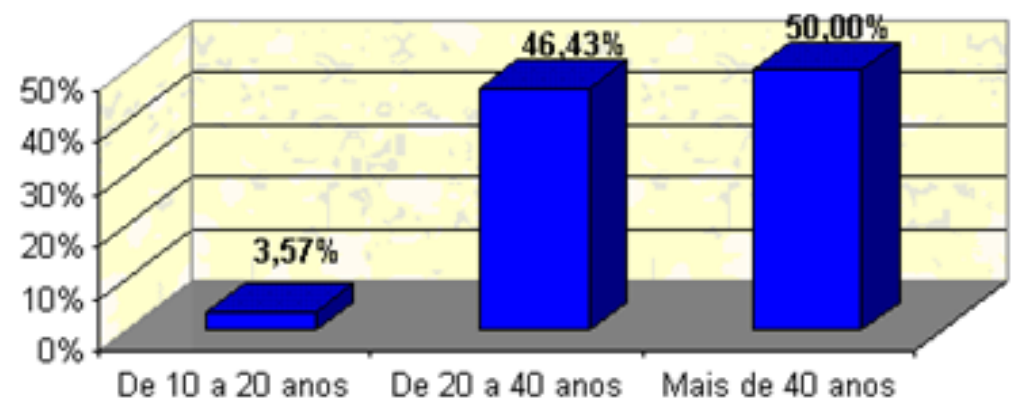

As respostas a essa questão revelam que a maioria das instituições pesquisadas, ou seja, 96,43\%, já atuam no mercado há mais de 20 (vinte) anos e que $50 \%$ já existem há mais de 40 (quarenta) anos. Este fato demonstra que a maioria das instituições, que possuem o certificado, são já consolidadas no mercado. 
b) Quantidade de alunos que a instituição possui

TABELA 03 - Quantidade de Alunos

\begin{tabular}{|l|c|c|}
\hline Opções & Freq.Absoluta & Freq.Relativa \\
\hline Menos de 1.000 & 4 & $14,29 \%$ \\
\hline De 1.000 a 5.000 & 10 & $35,71 \%$ \\
\hline De 5.000 a 10.000 & 4 & $14,29 \%$ \\
\hline De 10.000 a 20.000 & 6 & $21,43 \%$ \\
\hline Mais de 20.000 & 4 & $14,29 \%$ \\
\hline Total & 28 & $100,00 \%$ \\
\hline
\end{tabular}

\section{GRÁFICO 02 - Quantidade de Alunos}

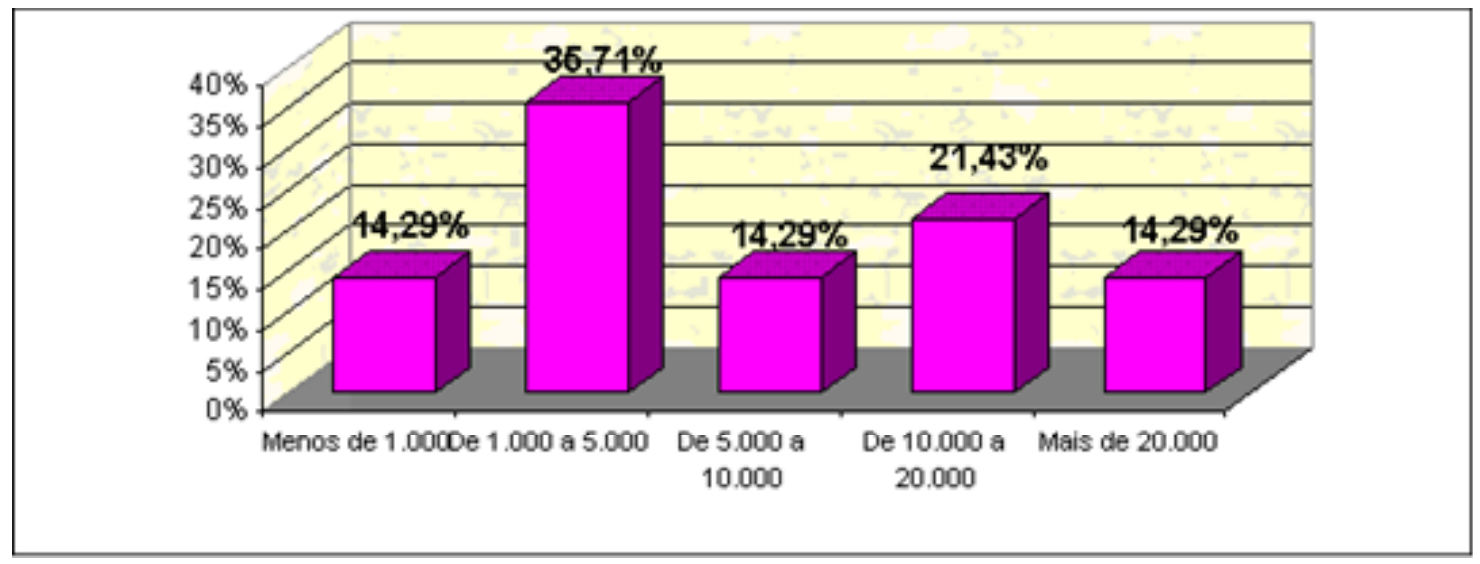

Os resultados demonstram a quantidade de alunos nas instituições pesquisadas, sendo constatado, dessa forma, sua participação no setor educacional do país. 
c) O Setor contábil próprio ou terceirizado

TABELA 04 - Setor Contábil

\begin{tabular}{|l|c|c|}
\hline Opções & Freq.Absoluta & Freq.Relativa \\
\hline Setor Contábil Próprio & 26 & $92,86 \%$ \\
\hline Setor Contábil Terceirizado & 2 & $7,14 \%$ \\
\hline Total & 28 & $100,00 \%$ \\
\hline
\end{tabular}

\section{GRÁFICO 03 - Setor Contábil}

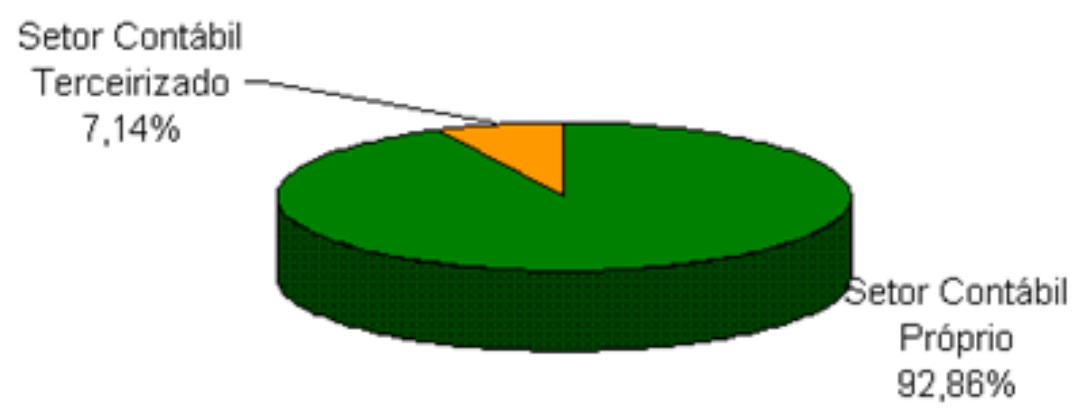

Verificou-se através das respostas, que a maioria das instituições possui setor contábil próprio e que somente duas instituições das pesquisadas terceirizam a sua contabilidade. 
a) Quanto tempo a instituição possui o Certificado?

TABELA 05 - Tempo que a instituição possui o certificado

\begin{tabular}{|c|c|c|}
\hline Opções & Freq.Absoluta & Freq.Relativa \\
\hline Até 3 anos & 0 & $0,00 \%$ \\
\hline De 3 a 5 anos & 2 & $7,14 \%$ \\
\hline Acima de 5 anos & 26 & $92,86 \%$ \\
\hline Total & 28 & $100,00 \%$ \\
\hline
\end{tabular}

\section{GRÁFICO 04 - Tempo que a instituição possui o certificado}

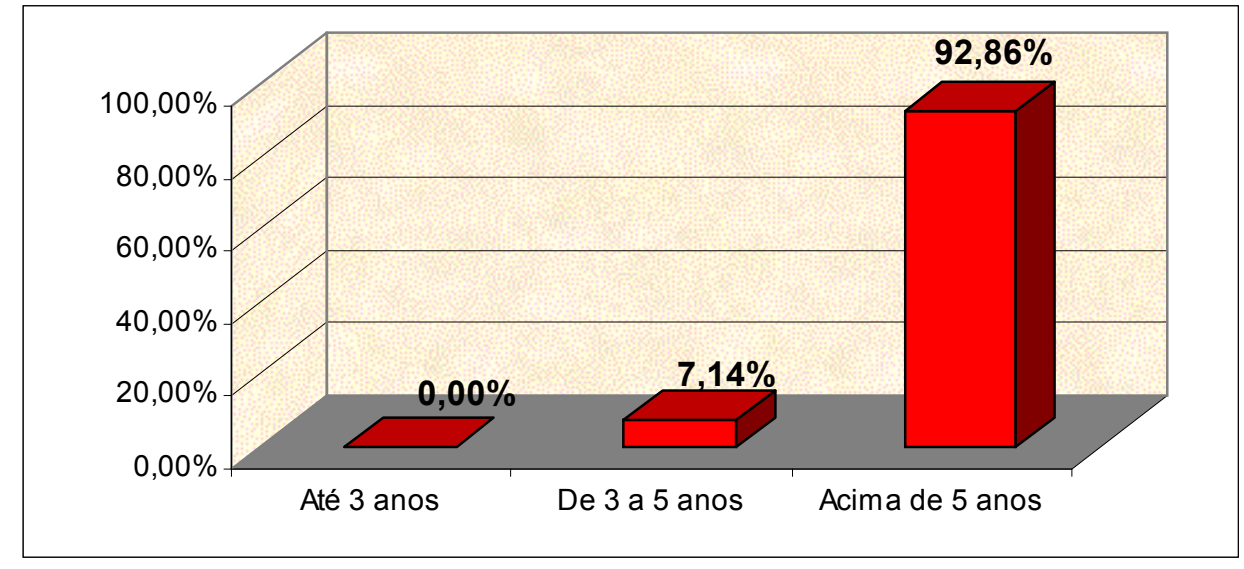

As respostas demonstram que a maioria absoluta das instituições já possui o certificado há mais de 05 (cinco) anos.

b) Qual a quantidade de alunos atendidos pela beneficência no ano de 2001 ? 
TABELA 06 - Alunos atendidos pela beneficência

\begin{tabular}{|l|c|c|}
\hline Opções & Freq.Absoluta & Freq.Relativa \\
\hline Até 500 & 4 & $14,29 \%$ \\
\hline De 501 a 1.000 & 3 & $10,71 \%$ \\
\hline Acima de 1000 & 20 & $71,43 \%$ \\
\hline Em branco & 1 & $3,57 \%$ \\
\hline Total & 28 & $100,00 \%$ \\
\hline
\end{tabular}

\section{GRÁFICO 05 - Alunos atendidos pela beneficência}

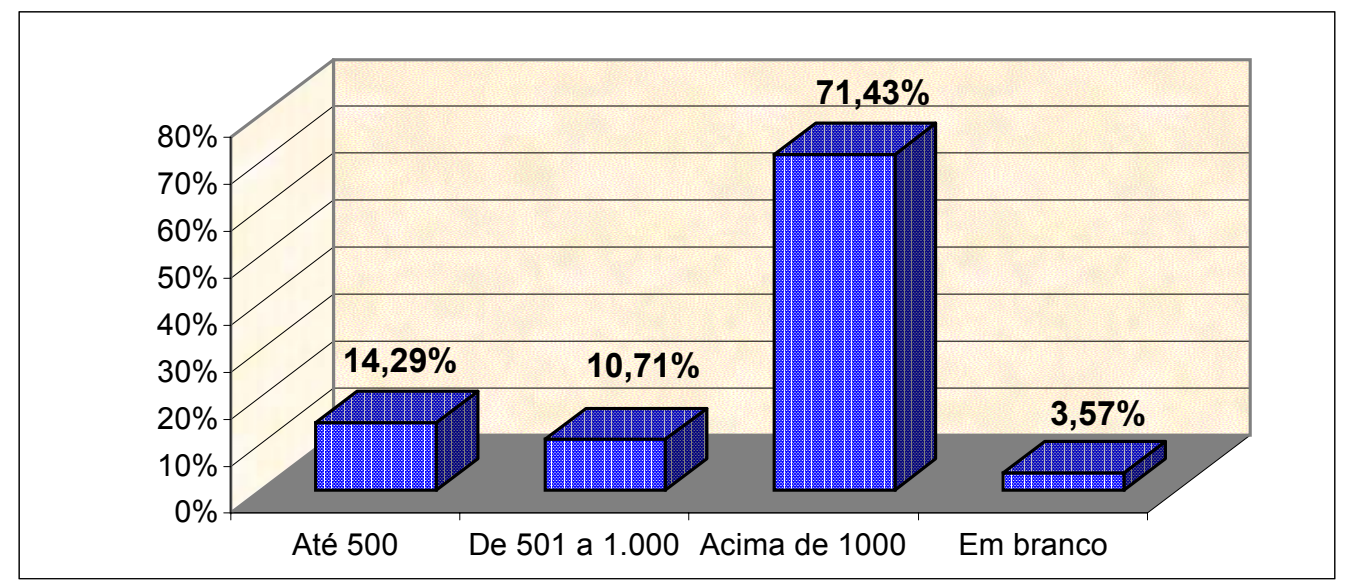

Segundo dados do Ministério da Educação, a previsão é que pelo menos 100.000 (cem mil) alunos serão atendidos em 2002 pelas instituições que possuem o certificado. O gráfico demonstra que a maioria atendeu mais de 1000 (mil) alunos em 2001. O resultado não permite comparação com os dados do Ministério da Educação, haja vista não se conhecer o tamanho da população, objeto da pesquisa.

c) Qual foi o valor gasto com beneficências no ano de 2001 ? 
TABELA 07 - Valor gasto com beneficência

\begin{tabular}{|l|c|c|}
\hline Opções & Freq.Absoluta & Freq.Relativa \\
\hline Até 3 milhões de R\$ & 9 & $32,14 \%$ \\
\hline De 3 a 5 milhões de R\$ & 4 & $14,29 \%$ \\
\hline Mais de 5 milhões de R\$ & 14 & $50,00 \%$ \\
\hline Em branco & 1 & $3,57 \%$ \\
\hline Total & 28 & $100,00 \%$ \\
\hline
\end{tabular}

\section{GRÁFICO 06 - Valor gasto com beneficência}

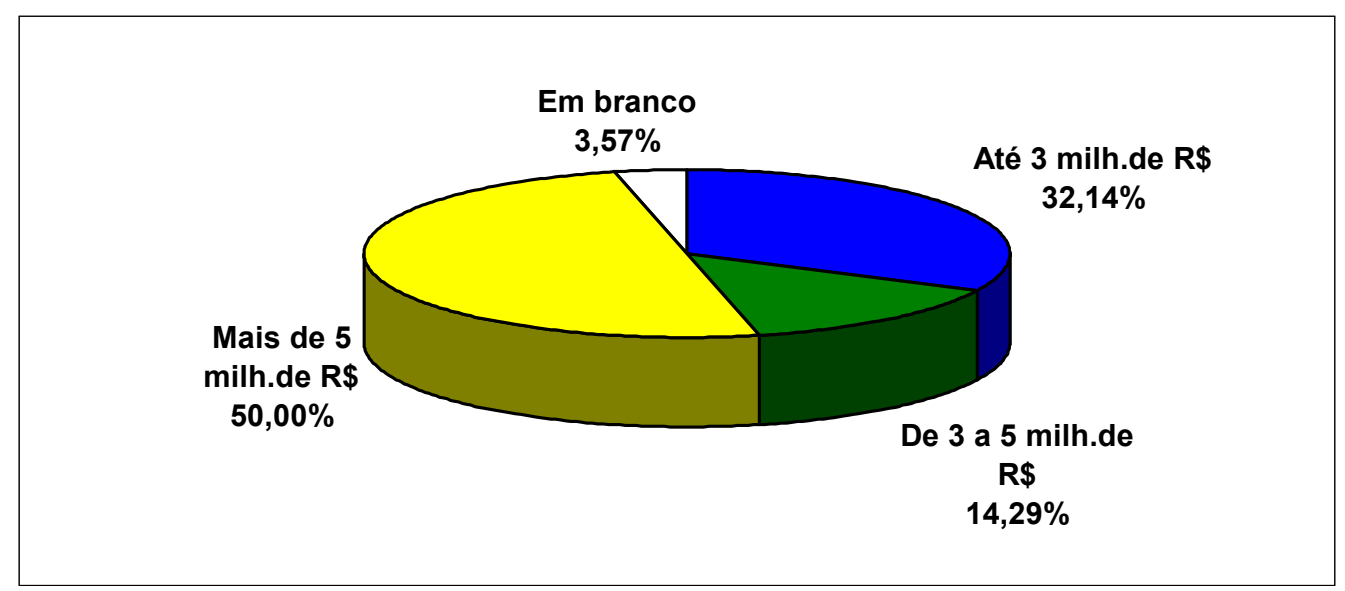

Cinqüenta por cento das instituições aplicou mais de cinco milhões de reais

em beneficências durante o exercício de 2001, sendo, dessa forma, significativos os valores, o que reforça a importância do trabalho.

d) Quais as áreas de atuação da instituição? 
TABELA 08 - Áreas de atuação ${ }^{16}$

\begin{tabular}{|l|c|c|}
\hline Opções & Freq.Absoluta & Freq.Relativa \\
\hline CCBS & 18 & $64,29 \%$ \\
\hline CCSA & 19 & $67,86 \%$ \\
\hline CCET & 17 & $60,71 \%$ \\
\hline Outros & 19 & $67,86 \%$ \\
\hline Total & 73 & \\
\hline
\end{tabular}

\section{GRÁFICO 07 - Áreas de atuação}

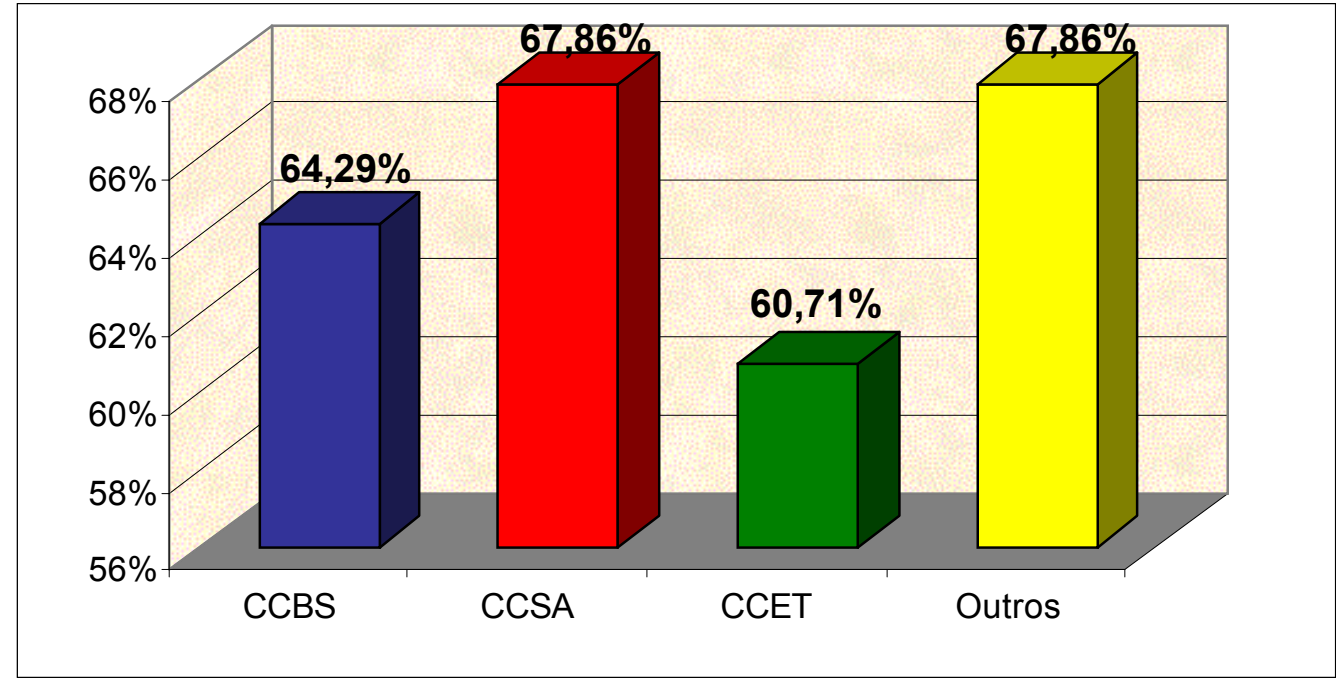

Procurou-se descobrir quais as áreas de atuação dessas instituições, no intuito de verificar a atuação no Centro de Ciências Biológicas e da Saúde, local onde ocorre aplicação de significativos valores em beneficências. Constatou-se, pois, que existe um equilíbrio nas áreas de atuação, mas a maioria dos cursos estão concentrados no Centro de Ciências Sociais Aplicadas e Outros conforme referenciado.

\section{TABELA 09 - Percentual de cada área de atuação}

\footnotetext{
${ }^{16}$ CCBS - Centro de Ciências Biológicas e da Saúde, CCSA - Centro de Ciências Sociais Aplicadas, CCET - Centro de Ciências Exatas e da Terra, e

Outros: CC Jurídicas, CCHS, Ciências Agrárias, Ciências Humanas, CCAA, Tecnologia e Urbanismo, Comunicação, Ensino Médio e Fundamental, Centro de Línguas e Comunicação, Assistência Social e Educação, Atendimento Hospitalar, Centro de Economia e Administração.
} 


\begin{tabular}{|r|c|c|c|r|r|}
\hline Quest.No. & CCBS & CCSA & CCET & Outros & \\
\hline 1 & $26,50 \%$ & $26,50 \%$ & $26,50 \%$ & $20,50 \%$ & $100,00 \%$ \\
\hline 2 & & & & $100,00 \%$ & $100,00 \%$ \\
\hline 3 & & & & & $0,00 \%$ \\
\hline 4 & & & & $100,00 \%$ & $100,00 \%$ \\
\hline 5 & & & & & $0,00 \%$ \\
\hline 7 & $11,00 \%$ & $35,00 \%$ & $27,00 \%$ & $27,00 \%$ & $100,00 \%$ \\
\hline 8 & $10,00 \%$ & $68,00 \%$ & $22,00 \%$ & & $100,00 \%$ \\
\hline 9 & $29,20 \%$ & $25,00 \%$ & $25,00 \%$ & $20,80 \%$ & $100,00 \%$ \\
\hline 10 & $30,27 \%$ & & & $100,00 \%$ & $100,00 \%$ \\
\hline 11 & & $32,57 \%$ & $9,68 \%$ & $27,48 \%$ & $100,00 \%$ \\
\hline 12 & $5,00 \%$ & & & $25,50 \%$ & $25,50 \%$ \\
\hline 13 & & $80,00 \%$ & & & $85,00 \%$ \\
\hline 14 & & & & & $0,00 \%$ \\
\hline 15 & $20,00 \%$ & $11,00 \%$ & $19,00 \%$ & $50,00 \%$ & $100,00 \%$ \\
\hline 16 & & $100,00 \%$ & & & $100,00 \%$ \\
\hline 17 & & $90,00 \%$ & $10,00 \%$ & & $100,00 \%$ \\
\hline 18 & $37,50 \%$ & $31,25 \%$ & $12,50 \%$ & $18,75 \%$ & $100,00 \%$ \\
\hline 19 & & & $100,00 \%$ & & $100,00 \%$ \\
\hline 20 & $100,00 \%$ & & & & $100,00 \%$ \\
\hline 21 & & & & & $0,00 \%$ \\
\hline 22 & $30,27 \%$ & $32,57 \%$ & $9,68 \%$ & $27,48 \%$ & $100,00 \%$ \\
\hline 23 & $25,53 \%$ & $29,41 \%$ & $18,54 \%$ & $26,52 \%$ & $100,00 \%$ \\
\hline 24 & $100,00 \%$ & & & & $100,00 \%$ \\
\hline 25 & $30,00 \%$ & $30,00 \%$ & & $40,00 \%$ & $100,00 \%$ \\
\hline 26 & $4,00 \%$ & $36,00 \%$ & $36,00 \%$ & $24,00 \%$ & $100,00 \%$ \\
\hline 27 & $37,00 \%$ & $37,00 \%$ & $26,00 \%$ & & $100,00 \%$ \\
\hline 28 & $30,74 \%$ & $11,00 \%$ & $8,80 \%$ & $49,46 \%$ & $100,00 \%$ \\
\hline
\end{tabular}

A tabela apresenta o percentual de cada área de cada instituição. Algumas instituições não responderam, justificando-se, dessa forma, as linhas com percentual 0 (zero).

e) Quais são os benefícios usufruídos em função do Certificado? 
TABELA 10 - Quanto aos benefícios

\begin{tabular}{|l|c|c|}
\hline Opções & Freq.Absoluta & Freq.Relativa \\
\hline INSS & 28 & $100,00 \%$ \\
\hline COFINS & 24 & $85,71 \%$ \\
\hline CSLL & 21 & $75,00 \%$ \\
\hline PIS & 12 & $42,86 \%$ \\
\hline IR & 20 & $71,43 \%$ \\
\hline Total & 105 & \\
\hline
\end{tabular}

\section{GRÁFICO 08 - Quanto aos benefícios}

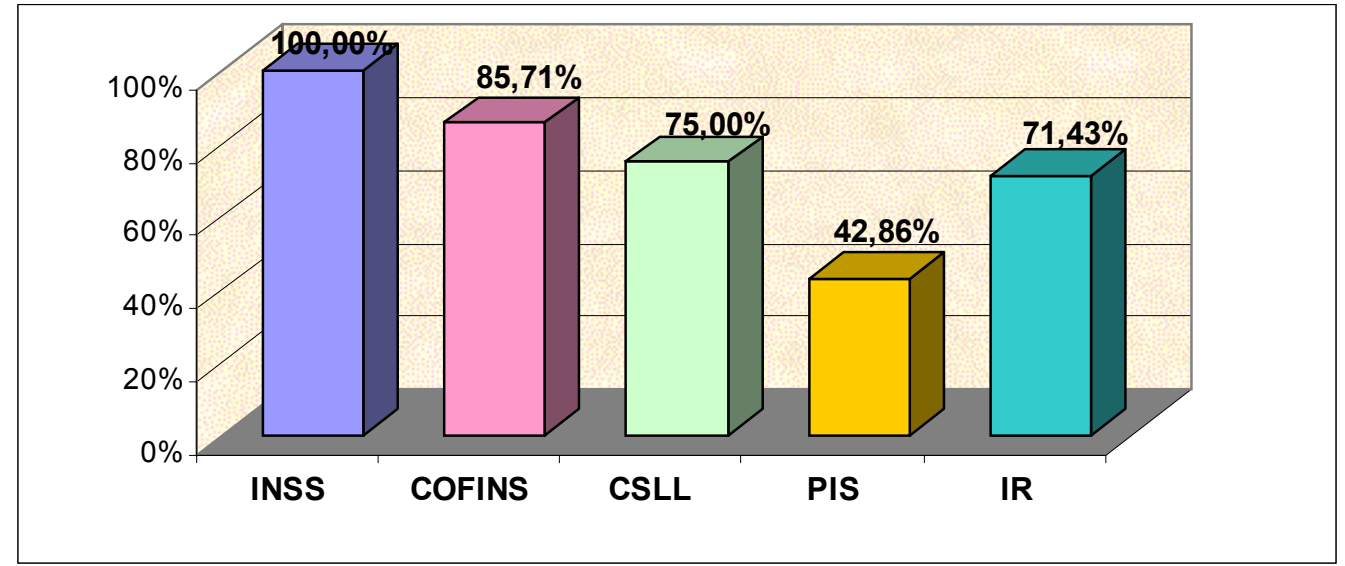

Constata-se, pois, que a totalidade das instituições pesquisadas reconhece o INSS como benefício em função do certificado, entretanto não existe clareza com relação aos outros benefícios. Os benefícios gerados pelo certificado são as contribuições para a seguridade social e que, de acordo com o Art. 22 e 23 da Lei 8.212, são: INSS, Cofins e Contribuição Social Sobre Lucro Líquido. O Imposto de Renda, conforme apresentado no capítulo I deste trabalho, não é devido, não em função do certificado, mas pela condição de instituição sem fins lucrativos que atua no ramo educacional. O PIS não é um benefício gerado pelo certificado, visto que essas instituições recolhem $1 \%$ (hum por cento) sobre o total da folha de pagamento.

f) Os gastos com beneficências foram superiores aos benefícios usufruídos em 2001? 
TABELA 11 - Relação gastos com beneficências x benefícios

\begin{tabular}{|l|c|c|}
\hline Opções & Freq.Absoluta & Freq.Relativa \\
\hline Gastos $>$ Benefícios & 21 & $75,00 \%$ \\
\hline Gastos< Benefícios & 5 & $17,86 \%$ \\
\hline Em branco & 2 & $7,14 \%$ \\
\hline Total & 28 & $100,00 \%$ \\
\hline
\end{tabular}

\section{GRÁFICO 09 - Relação gastos com beneficências x benefícios}

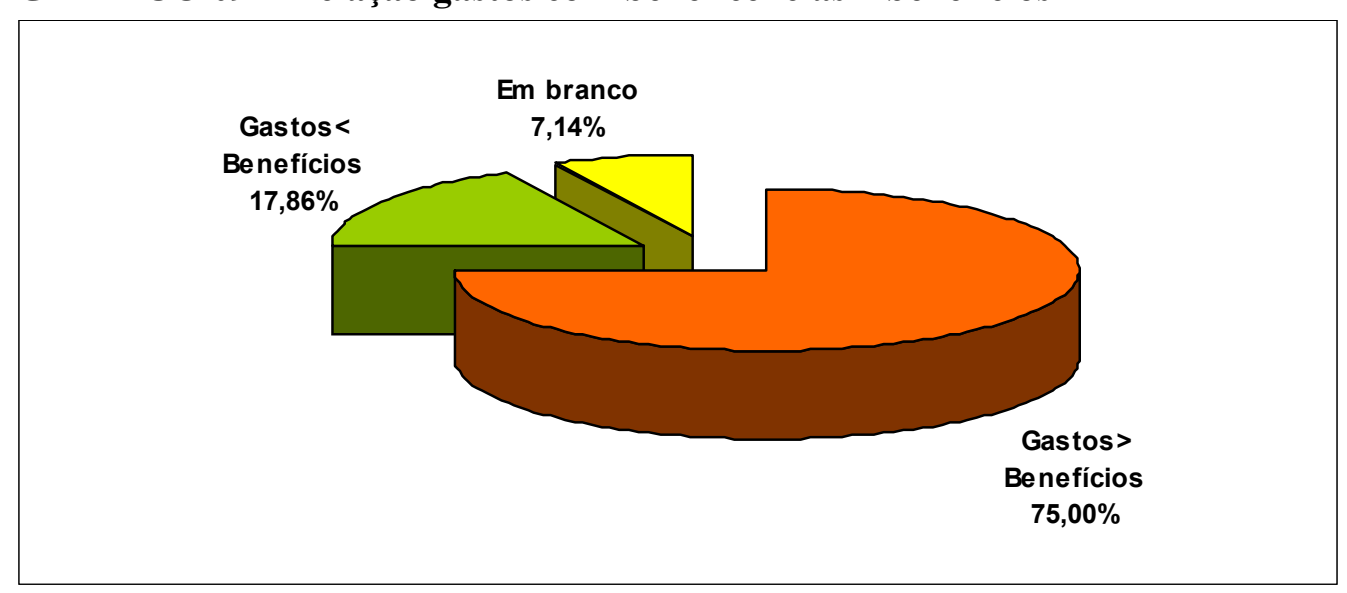

Verifica-se, diante das respostas, um problema, visto que 5 (cinco) instituições responderam que os seus gastos foram menores que os beneficios usufruídos. De acordo com a legislação apresentada, os valores gastos com beneficências nunca podem ser inferiores ao valor dos benefícios usufruídos.

É possível, que em função das respostas apresentadas na tabela 10, mesmo as instituições que responderam que os gastos foram inferiores aos benefícios, possam ter atendido a legislação, haja vista que trata-se apenas dos benefícios 
específicos do certificado. Infere-se, pois diante do exposto, que, como nem todas as instituições sabem quais são os benefícios, conforme se constatou, é possível que nem em todas as instituiç̃̃es que responderam que os seus gastos são inferiores aos beneficios esse fato seja verdadeiro.

Constata-se pois a partir das respostas, que como a maioria das instituições gasta mais dos que os benefícios, e como as mesmas consideram outros benefícios além dos específicos do certificado, que estas instituições estão gastando mais do que se exige, ou seja o mesmo valor que se deixou de recolher com a seguridade social. Não se pode afirmar entretanto, que estas estão aplicando mais do que o percentual exigido, haja vista que esse percentual pode não ser suficiente para atender o dispositivo legal ou seja, no mínimo igual aos benefícios usufruídos em função do certificado.

g) Quais as obrigações que a instituição tem para manter os benefícios do Certificado?

TABELA 12 - Obrigações da instituição

\begin{tabular}{|l|c|c|}
\hline Opções & Freq.Absoluta & Freq.Relativa \\
\hline Aplicar 20\% em Beneficências & 25 & $89,29 \%$ \\
\hline
\end{tabular}




\begin{tabular}{|l|c|c|} 
Aplicar 20\% em Bolsas de & & \\
Est. & 8 & $28,57 \%$ \\
\hline Ambas & 3 & $10,71 \%$ \\
\hline Em branco & 1 & $3,57 \%$ \\
\hline Total & 37 & \\
\hline
\end{tabular}

\section{GRÁFICO 10 - Obrigações da instituição}

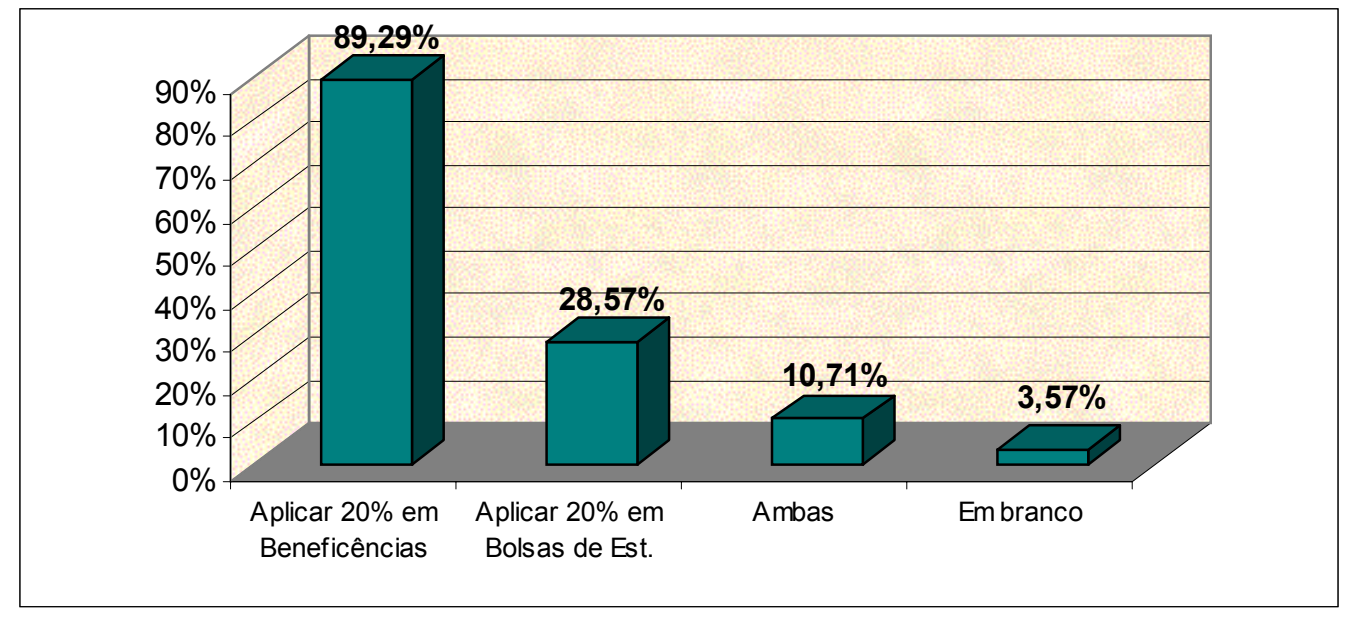

O gráfico mostra o desconhecimento que algumas instituições têm com relação às obrigações que possuem para manter os benefícios do Certificado. De acordo com o Decreto $\mathrm{n}^{\mathrm{o}} 2.536$, as instituições portadoras do certificado devem aplicar anualmente $20 \%$ da sua receita bruta total, excluídas somente as receitas com imobilizado, em beneficências. Esse desconhecimento pode estar trazendo prejuízos para a instituição. É claro que, se a instituição aplicar $20 \%$ em bolsas de estudo, estará também, dessa forma, cumprindo com a sua obrigação, entretanto, se possuir outros tipos de beneficências, estará, desse modo, gastando mais do que o necessário. Vale ressaltar que esses $20 \%$ devem ser superiores aos benefícios usufruídos, conforme determina a legislação.

\section{QUANTO ÀS INFORMAÇÕES}

a) Como são contabilizadas as beneficências realizadas?

\section{TABELA 13 - Forma de contabilização das beneficências}




\begin{tabular}{|l|c|c|}
\hline Opções & Freq.Absoluta & Freq.Relativa \\
\hline Contas de Resultado & 22 & $78,57 \%$ \\
\hline Contas de Compensação & 10 & $35,71 \%$ \\
\hline Em branco & 1 & $3,57 \%$ \\
\hline Total & 33 & \\
\hline
\end{tabular}

\section{GRÁFICO 11 - Forma de contabilização das beneficências}

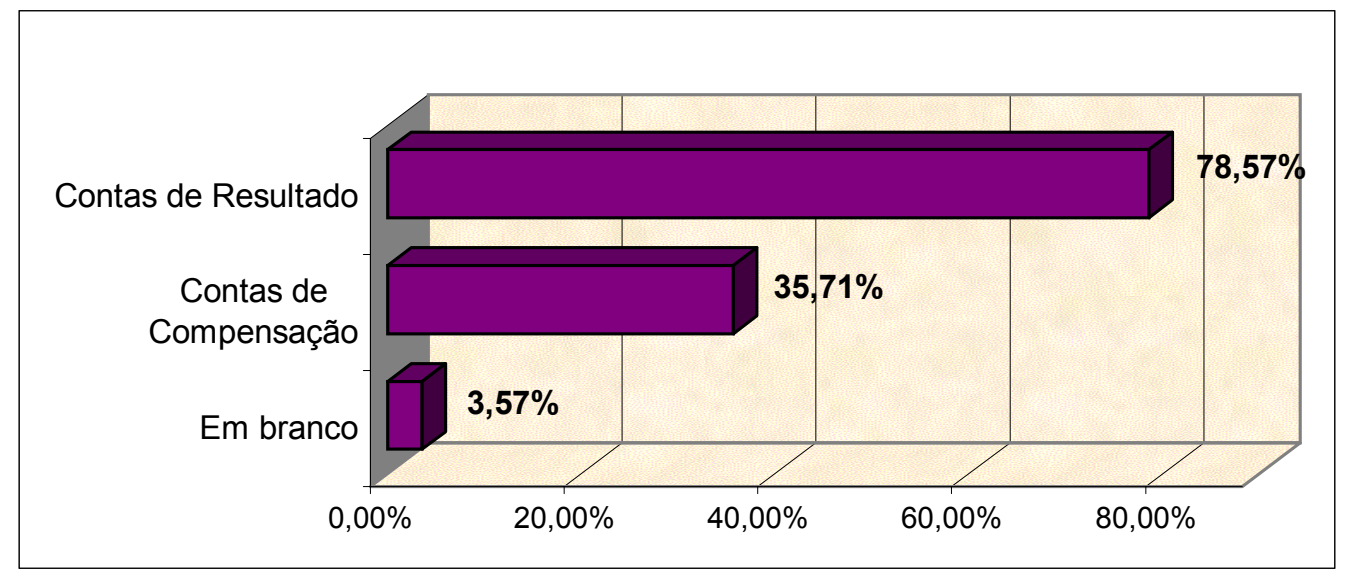

As beneficências realizadas representam, na maioria dos casos, receitas que a instituição deixou de receber em função de uma obrigação para com o certificado. Verifica-se, pois, através das respostas, que não existe uniformidade nos procedimentos, sendo que a maioria contabiliza em contas de resultado e um percentual significativo de instituições contabiliza em contas de compensação. Esse procedimento, prejudica a comparação das demonstrações das instituições, haja vista a diferença de procedimentos no registro dos fatos.

b) Os custos com as beneficências são apurados?

TABELA 14 - Apuração dos custos

\begin{tabular}{|l|c|c|}
\hline Opções & Freq.Absoluta & Freq. Relativa \\
\hline Sim apuram custos & 20 & $71,43 \%$ \\
\hline
\end{tabular}




\begin{tabular}{|l|c|c|} 
Não apuram custos & 8 & $28,57 \%$ \\
\hline Total & 28 & $100,00 \%$ \\
\hline
\end{tabular}

\section{GRÁFICO 12 - Apuração dos custos}

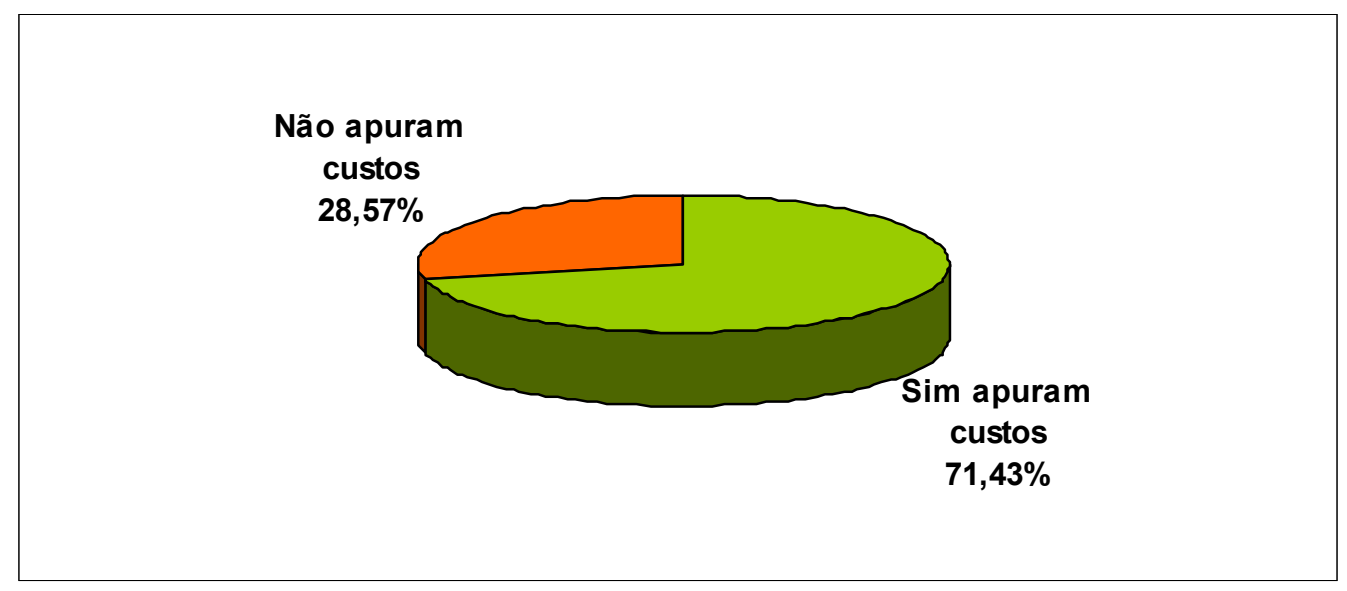

A grande maioria respondeu que apura os custos, significando, dessa forma, que atribuem grande importância a esse item, porém existe um percentual elevado de instituições que não apuram seus custos deixando de prestar uma informação importantíssima para os dirigentes.

c) Como são contabilizados os benefícios obtidos com o Certificado?

TABELA 15 - Forma de contabilização dos benefícios

\begin{tabular}{|l|l|l|}
\hline Opções & Freq.Absoluta & Freq.Relativa \\
\hline Contas de resultados & 8 & $28,57 \%$ \\
\hline Contas de Compensação & 12 & $42,86 \%$ \\
\hline Não são contabilizados & 10 & $35,71 \%$ \\
\hline Total & 30 & \\
\hline
\end{tabular}




\section{GRÁFICO 13 - Forma de contabilização dos benefícios}

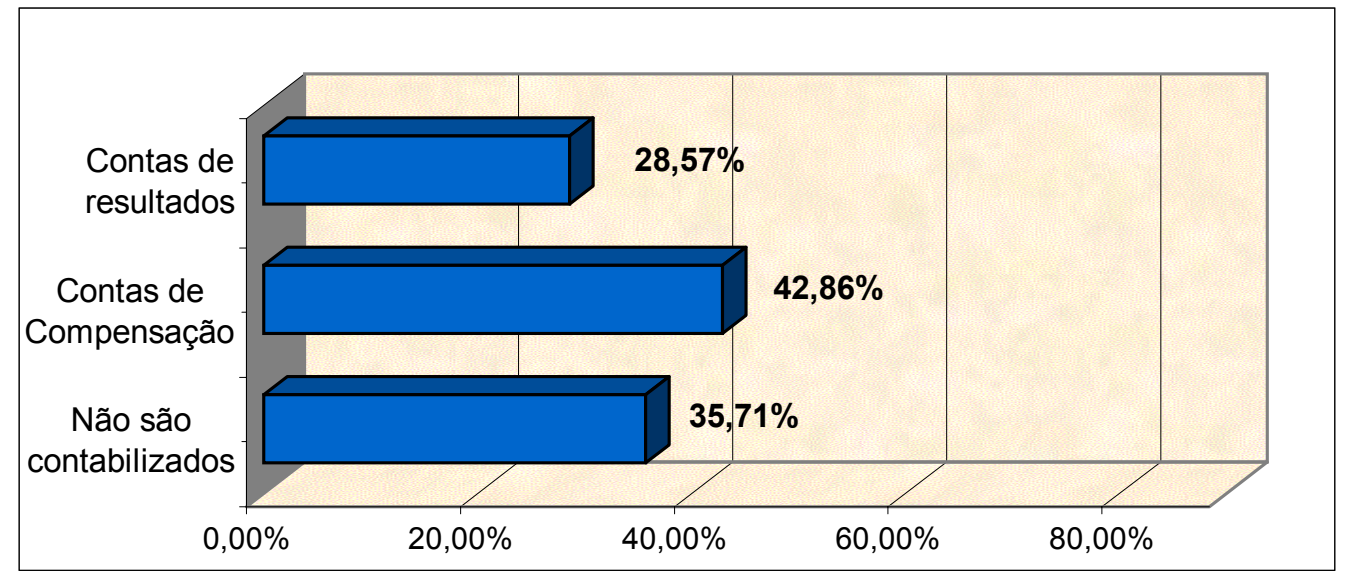

Novamente aqui, como ocorreu na questão forma de contabilização das beneficências, demonstradas no gráfico 11, verifica-se que não existe uniformidade nos procedimentos, ocorrendo aqui também um contraste entre as respostas. Nas respostas apresentadas no gráfico $11,75 \%$ responderam que contabilizam as beneficências em contas de resultado, entretanto, somente $28,57 \%$ contabilizam os benefícios em contas de resultado. A maioria contabiliza em contas de compensação e um número significativo de instituições não contabiliza. Esse fato, contraria o princípio do confronto das despesas com as receitas e com os períodos contábeis, conforme pode ser observado no capítulo 5 .

d) O resultado entre as receitas e despesas do Certificado são apuradas?

TABELA 16 - Apuração de resultado

\begin{tabular}{|l|c|c|}
\hline Opções & Freq.Absoluta & Freq.Relativa \\
\hline Sim apuram o resultado & 14 & $50,00 \%$ \\
\hline Não apuram o resultado & 14 & $50,00 \%$ \\
\hline Total & 28 & $100,00 \%$ \\
\hline
\end{tabular}




\section{GRÁFICO 14 - Apuração de resultado}

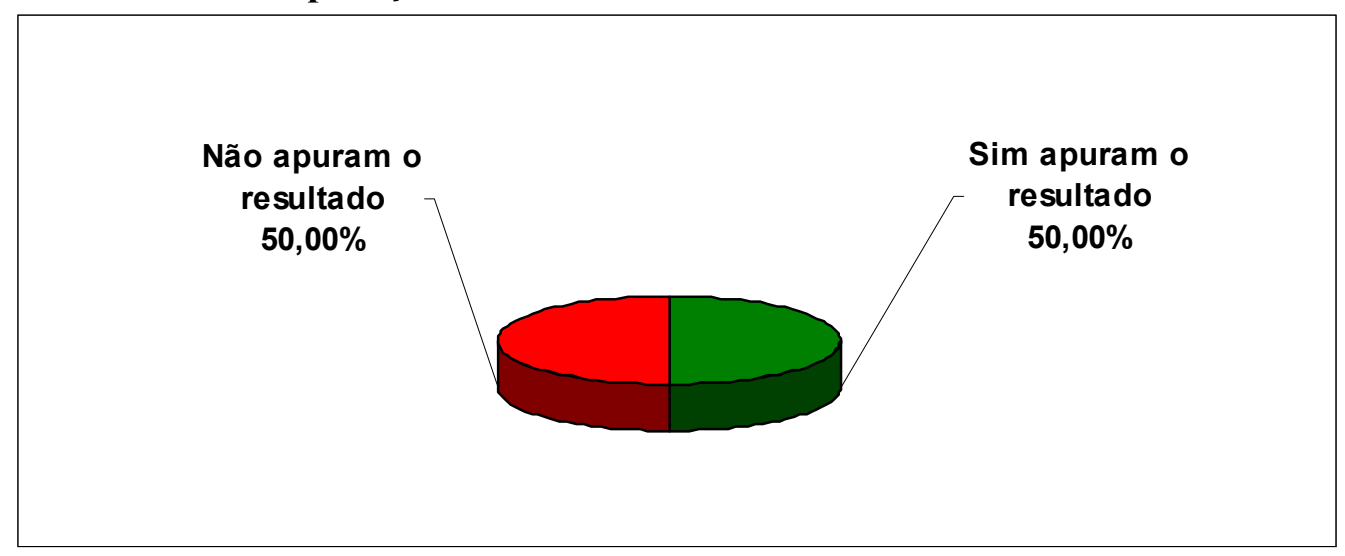

Constata-se, pois, através das respostas, que a metade das instituições não apuram o resultado entre as receitas e despesas com certificado. Essa resposta não guarda coerência com a resposta demonstrada no gráfico $\mathrm{n}^{\circ} 12$, visto que a maioria das instituições apura os custos com o certificado, entretanto, nem todas as instituições que apuram os custos, apuram o resultado.

e) Se positivo, como são demonstrados?

\section{TABELA 17 - Demonstração dos resultados}

\begin{tabular}{|l|c|c|}
\hline Opções & Freq.Absoluta & Freq.Relativa \\
\hline DRE & 10 & $35,71 \%$ \\
\hline Notas explicativas & 23 & $82,14 \%$ \\
\hline Balanço & 4 & $14,29 \%$ \\
\hline Outros & 10 & $35,71 \%$ \\
\hline Total & 37 & \\
\hline
\end{tabular}




\section{GRÁFICO 15 - Demonstração dos resultados}

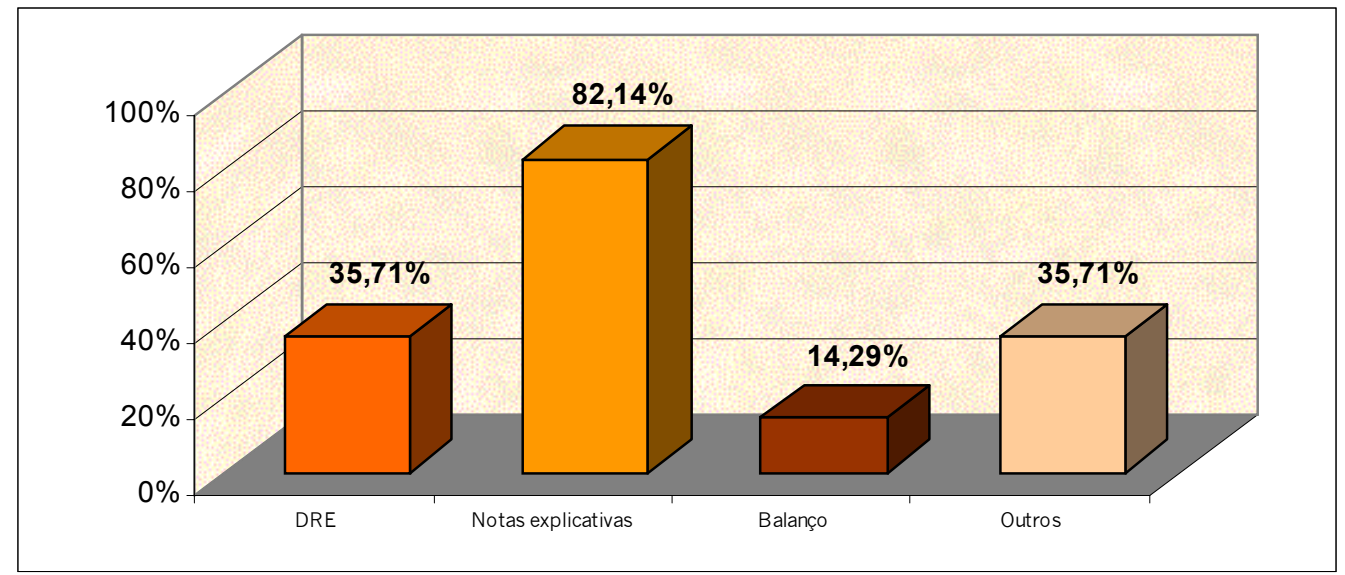

As respostas demonstram que a maioria das instituições apresenta o resultado com a beneficência em notas explicativas e esse fato contraria as respostas demonstradas através do gráfico 14, em que metade das instituições responderam que não apuram os custos com o certificado. Se não apuram os custos como podem apurar o resultado? O objetivo da questão foi verificar como as instituições demonstram o resultado com a beneficência, sendo permitida a resposta a mais de um item, quando esse fato ocorresse.

f) É apurado o resultado total da instituição, incluindo o resultado obtido com o Certificado?

TABELA 18 - Apuração do resultado total

\begin{tabular}{|l|c|c|}
\hline Opções & Freq.Absoluta & Freq.Relativa \\
\hline Sim apuram o resultado total & 15 & $53,57 \%$ \\
\hline Não apuram o resultado total & 13 & $46,43 \%$ \\
\hline Total & 28 & $100,00 \%$ \\
\hline
\end{tabular}




\section{GRÁFICO 16 - Apuração do resultado total}

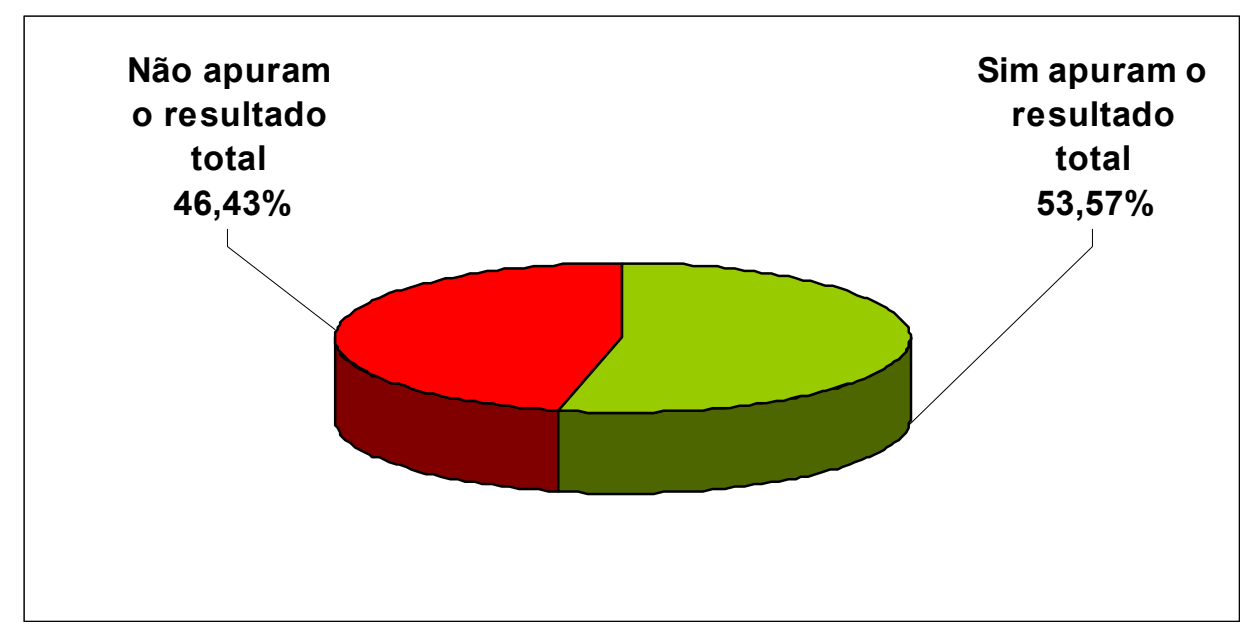

As respostas a essa questão, também, não encontram coerência com as anteriores, visto que a maioria não contabiliza ou contabiliza em contas de compensação os benefícios obtidos com o certificado e metade não apura os custos. De que forma pode-se apurar o resultado total sem apurar o custo ou mesmo não contabilizando os benefícios? Verifica-se, pois, diante dessa questão, que possa ter havido algum equívoco, quando do preenchimento do questionário.

g) Quais os relatórios/informações apresentados aos administradores e dirigentes sobre as beneficências?

\section{TABELA 19 - Relatórios apresentados ${ }^{17}$}

\begin{tabular}{|l|c|c|}
\hline Opções & Freq.Absoluta & Freq.Relativa \\
\hline Balanço Patrimonial & 16 & $57,14 \%$ \\
\hline D.R.E. & 20 & $71,43 \%$ \\
\hline Nenhum & 1 & $3,57 \%$ \\
\hline Outros & 12 & $42,86 \%$ \\
\hline
\end{tabular}

17 Outros: Balanço social e relatório mensal contendo todas as informações de beneficência social, relatórios paralelos, relatórios gerenciais (3), Relatório de Filantropia (2), Planilha de cálculo filantropia e Relatório de Serviços assistenciais gratuitos, notas explicativas, balancetes e fluxos de caixa, relatório de atividades, demonstrativos, gráficos e no Balanço. 


\begin{tabular}{l|l|l|} 
Total & 49 & \\
\hline
\end{tabular}

\section{GRÁFICO 17 - Relatórios apresentados}

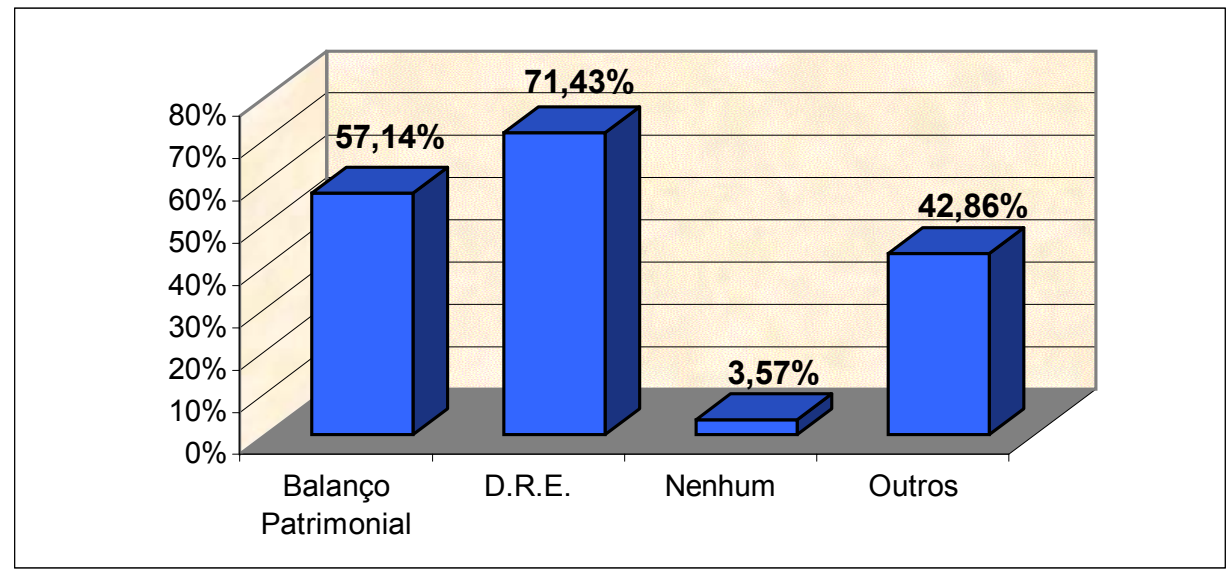

A grande maioria respondeu que apresenta a Demonstração do Resultado do Exercício e o Balanço aos dirigentes com a fonte de informações sobre as beneficências. Ressalte-se, pois, que as duas demonstrações contábeis não são suficientes, pelas respostas, para dar todas as informações sobre as beneficências, sendo complementadas por outros relatórios ou informações, conforme se verifica através das respostas. 
h) Você considera que as normas estabelecidas na NBC T 10.19 do CFC podem ajudar os administradores/dirigentes na tomada de decisão?

TABELA 20 - NBC T 10.19 do CFC

\begin{tabular}{|l|c|c|}
\hline Opções & Freq.Absoluta & Freq.Relativa \\
\hline Normas ajudam & 23 & $82,14 \%$ \\
\hline Normas não ajudam & 3 & $10,71 \%$ \\
\hline Em branco & 2 & $7,14 \%$ \\
\hline Total & 28 & $100,00 \%$ \\
\hline
\end{tabular}

\section{GRÁFICO 18 - NBC T 10.19 do CFC}

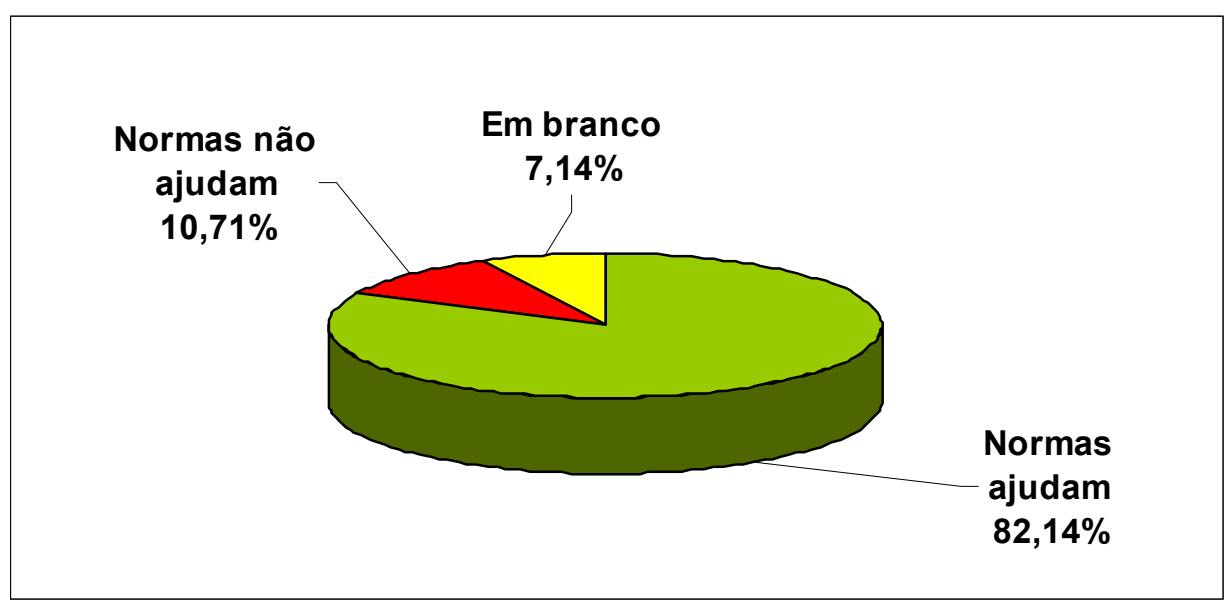

A grande maioria considera que as normas estabelecidas através da NCB T 10.19 podem ajudar os dirigentes quando da tomada de decisão, entretanto, três instituições responderam que não ajudam e duas não responderam, talvez porque desconheçam a referida norma ou considerem que ela nem ajuda e nem atrapalha. 


\section{CAPÍTULO 4 - PROPOSTA DE APURAÇÃO E EVIDENCIAÇÃO DOS RESULTADOS DAS IESCEBAS}

Diante do que foi verificado na pesquisa empírica e pelos estudos realizados, constatou-se, que o certificado gera impactos patrimoniais e econômicos nas instituições e que a contabilidade como ciência que controla e registra as variações patrimoniais, deve apurar e evidenciar esses impactos.

Em termos metodológicos, objetiva-se, testar a hipótese de que o certificado gera resultados que devem ser apurados e evidenciados pela contabilidade das IESCEBAS.

\subsection{Beneficências/Gratuidades}

As beneficências ou gratuidades são serviços que as instituições possuidoras do certificado de entidades de fins filantrópicos estão obrigadas a prestar à comunidade carente como forma de compensar os valores a título de seguridade social não repassado para o Tesouro Nacional.

Alguns tipos de serviços, de acordo com o Parecer/ CJ/ no 2414/2001, não são aceitos como beneficências, "sejam porque conferidos a todos indistintamente, sejam porque não se destinam a suprir uma necessidade básica do cidadão ou mesmo 
então porque se destinam a qualificar funcionários ou conceder-lhes benefícios trabalhistas.”

Esclarece o referido parecer que a concessão de benefícios a todos indistintamente, como é o caso dos descontos oferecidos uniformemente a todos os alunos, não configura beneficência, visto que não verifica a necessidade do aluno. No que tange à questão de suprir a necessidade básica do cidadão, esclarece o parecer que a concessão de espaço na instituição para empresas ou para a comunidade para a realização de palestras, seminários etc, não podem também ser considerados como beneficências. Os benefícios fornecidos com caráter trabalhistas ou de qualificação, assim entendidos os gastos com aperfeiçoamento de professores, planos de saúde a funcionários e as bolsas de estudo aos filhos de funcionários, são exclusivamente, segundo o parecer, de cunho trabalhista, não podendo ser considerados como beneficências.

Observadas as restrições apresentadas, as beneficências, no caso das instituições objeto de estudo, ocorrem, na grande maioria, através da prestação de serviço escolar e clínica escola à comunidade carente ou a quem dela necessitar. Para que essas prestações de serviço ocorram, são necessários sacrifícios de recursos por parte das instituições.

\subsection{Custos, Receitas, Ativos e Passivos}

Segundo MARTINS (2000:25) “Custo são gastos relativos a bem ou serviço utilizado na produção de outros bens ou serviços". Por esse entendimento, constatase, pois, que as instituições para colocar os serviços à comunidade incorrem em 
custos. Como exemplo de custos, temos a mão-de-obra necessária para prestar serviços escolares e nas clínicas escolas.

Esses serviços de beneficências são prestados não por opção da instituição, mas por obrigação para a manutenção do certificado.

Esses serviços, conforme se pode verificar nas demonstrações em análise, não estão sendo contabilizados em contas de resultados no grupo de receitas. Diante desse fato, necessário se faz resgatar os conceitos de receita na visão de diversos autores.

Segundo a Equipe de Professores da FEA/USP (1998:66): “Entende-se por receita a entrada de elementos para o ativo, sob a forma de dinheiro ou direitos a receber, correspondentes, normalmente, à venda de mercadorias, de produtos ou à prestação de serviços".

Verifica-se, pois, que no caso das beneficências prestadas pelas IESCEBAS não há por parte de quem recebe os serviços pagamento ou compromisso de pagamento, não ocorrendo, dessa forma, pelo menos nessa visão a entrada de elementos para o ativo.

IUDÍCIBUS(2000:155) define receita como:

"a expressão monetária, validada pelo mercado, do agregado de bens e serviços da entidade, em sentido amplo (em determinado periodo de tempo), e que provoca um acréscimo concomitante no ativo e no patrimônio líquido, considerado separadamente da diminuição do ativo (ou do acréscimo do passivo) e do patrimônio líquido provocados pelo esforço em produzir tal receita".

Analisando a situação das beneficências, verifica-se, pois, conforme abordado anteriormente, que são necessários sacrifícios para a sua realização, 
ocorrendo diminuição do ativo (ou acréscimo do passivo) e do patrimônio líquido. Ocorre, portanto, a validação pelo mercado, através do CNAS, entidade que concede o certificado, que aceita os valores praticados no mercado, quer seja de mensalidades escolares ou no atendimento das clinicas, para fins de cumprimento da obrigação para com o certificado.

De acordo com o FASB apud SILVA (2000:163):

"Receitas são entradas ou outros aumentos de ativos de uma entidade ou liquidação de seus passivos (ou combinação de ambos), durante um periodo proveniente da entrega ou produção de mercadorias, prestação de serviços, ou outras atividades que constituem as principais ou centrais operações em andamento da entidade".

O conceito apresentado pelo FASB aproxima-se bem da situação que ocorre nas IESCEBAS, ficando claro que as beneficências são receitas para esstas instituições, ocorrendo um aumento de ativo, que será compensado através da liquidação de seus passivos, que são as contribuições para a seguridade social.

Se existem custos, devem existir receitas, conforme determina o regime de competência (Apêndice A). Sobre esse assunto IUDÍCIBUS, MARTINS e GELBCKE (2000:58):

"Toda despesa diretamente delineável com as receitas reconhecidas em determinado período, com as mesmas deverá ser confrontada; os consumos ou sacrificios de ativos (atuais ou futuros), realizados em determinado período e que não puderam ser associados à receita do período nem às dos períodos futuros, deverão ser descarregados como despesa do período em que ocorrerem..."

O Conselho Federal de Contabilidade, através da Resolução n ${ }^{\circ}$ 750, de 29 de dezembro de 1993, que dispôs sobre os Princípios Fundamentais de Contabilidade 
(PFC), definiu:

“Art. $9^{\circ}$ As receitas e as despesas devem ser incluídas na apuração do resultado do período em que ocorrerem, sempre simultaneamente quando se correlacionarem, independentemente de recebimento ou pagamento".

Verifica-se, pois, que as receitas e as despesas devem ser confrontadas no período em que ocorrerem. Nota-se que, não contabilizar as beneficências em contas de resultados e contabilizar os custos, essa confrontação não ocorre.

Diante dos conceitos apresentados, torna-se necessário à apresentação de alguns conceitos de ativo e passivo, com o intuito de contribuir para o entendimento do assunto.

HENDRIKSEN \& BREDA (1999:283), ao tratarem das definições de ativo e passivo, explicam que tais definições são importantes "para que a teoria da contabilidade proporcione as diretrizes adequadas visando o desenvolvimento do pensamento contábil e de princípios da contabilidade”. Entretanto, os autores ressaltam que "a ênfase inicial deve residir nas características que são comuns a todos os ativos e passivos”.

Nesse aspecto, o FASB apud HENDRIKSEN \& BREDA (1999:283), através do SFAC 6, definiu ativos e passivos da seguinte forma:

“Ativos são benefícios econômicos futuros prováveis, obtidos ou controlados por uma dada entidade em consequência de transações ou eventos passados".

"Passivos são sacrifícios futuros prováveis de benefícios econômicos decorrentes de obrigações presentes de uma dada entidade, quanto à transferência de ativos ou prestação de serviços a outras entidades no futuro, em consequência de transações ou eventos passados". 
IUDÍCIBUS (2000:124), firma seu posicionamento concluindo que:

"1. o ativo deve ser considerado à luz da sua propriedade elou à luz de sua posse e controle; normalmente as duas condições virão juntas;

2. precisa estar incluído no ativo, em seu bojo, algum direito específico a beneficios futuros (...), ou, em sentido mais amplo, o elemento precisa apresentar uma potencialidade de serviços futuros (...) para a entidade;

3. o direito precisa ser exclusivo da entidade; (...)".

No que diz respeito ao passivo, IUDÍCIBUS (2000:140-141) afirma:

"1. As exigibilidades deveriam referir-se a fatos já ocorridos (transações ou eventos), normalmente a serem pagas em um momento especifico futuro de tempo, podendo-se, todavia, reconhecer certas exigibilidades em situações que, pelo vulto do cometimento que podem acarretar para a entidade (mesmo que os eventos caracterizem a exigibilidade legal apenas no futuro), não podem deixar de ser contempladas. Poderiam estar incluidos nesta última categoria, digamos, o valor atual das indenizações futuras (...)

2. Note-se, todavia, que, embora os fatos que provocam a exigibilidade legal se configurem às vezes no futuro, de alguma forma o fato gerador da exigibilidade está relacionado a eventos passados ou presentes, não se podendo, apenas, prever exatamente quanto e quando, senão recorrendo a cálculos previsionais e atuariais.

3. Por outro lado, se é prática comercial comum indenizar, total ou parcialmente, terceiros por eventos que, mesmo não sendo considerados obrigações legais, de certa forma foram devidos a falhas de cumprimento de condições usuais de comércio (devoluções, etc.), seria viável o provisionamento de tais encargos. (...)”

Pode-se perceber com os conceitos anteriormente elencados que as beneficências ou gratuidades apresentam características de ativos e passivos, pois a natureza dos fatos envolvidos é idêntica.

Quando a instituição faz a opção pelo certificado, passa a ter a obrigação de aplicar no mínimo $20 \%$ da receita bruta total em gratuidades ou beneficências. Ao realizar as gratuidades, a instituição estará gerando um ativo que irá amortizar o seu passivo, ou seja as contribuições sociais não repassadas ao governo, em função de 
possuir o certificado.

Não considerar esses fatos pela Contabilidade, como foi constatado, significa desprezar a teoria contábil e também, não conhecer sua realidade econômico-financeira.

\subsection{Custo de Oportunidade}

Antes de fazer a opção pelo certificado, as instituições devem proceder à escolha entre as alternativas existentes e esse fato é denominado de custo de oportunidade.

Nesse sentido, BILAS (1976:168) diz que: “O custo dos fatores para uma empresa é igual aos valores destes mesmos fatores em seus melhores usos alternativos. Esta é uma doutrina dos custos alternativos ou de oportunidade e é a que o economista aceita quando fala de custos de produção".

Essa idéia também é defendida por MILLER (1981:188) ao afirmar que:

"O custo tem um significado muito especial em Economia, não apenas quando nos referimos à teoria da firma mas também quando nos referimos à tomada de decisões do consumidor. $O$ custo em economia significa apenas uma coisa - o custo de oportunidade".

A Economia busca auxílio no mercado para encontrar o custo de oportunidade dos fatores de produção, portanto, o mercado desempenha importante papel na determinação do custo de oportunidade.

Diante de uma abordagem contábil, HORNGREN, FOSTER \& DATAR (2000:277) definem que: "Custo de oportunidade é a contribuição para o lucro de 
que se abre mão pela não-utilização de um recurso limitado na sua melhor opção de uso".

Nesse sentido, PEREIRA in CATELLI (2001:389) define:

"Custo de oportunidade corresponde ao valor de um determinado recurso em seu melhor uso alternativo. Representa o custo da escolha de uma alternativa em detrimento de outra capaz de proporcionar um maior beneficio, ou seja, é o custo da melhor oportunidade a que se renuncia quando da escolha de uma alternativa".

Partindo-se desse enfoque e sabendo-se que os problemas residem na tomada de decisões entre diversas alternativas, segundo o mesmo autor, "o custo de oportunidade expressa o benefício efetivamente obtido de uma decisão, considerando o melhor uso alternativo dos recursos envolvidos". Dessa forma, o autor define que uma decisão é decorrente "do confronto entre o benefício gerado pela alternativa escolhida e o benefício que seria obtido pela escolha da melhor alternativa abandonada", de onde advém o conceito de custo de oportunidade.

Esse conceito é caracterizado por ser utilizado, geralmente, quanto existem várias alternativas sobre a aplicação de capital. Diante de algumas alternativas, entende-se que o investidor deverá arcar com os custos de oportunidade ao optar por uma delas em detrimento das demais, pois, ao fazê-lo, estará perdendo os benefícios das demais. Nesse sentido, NASCIMENTO in MARTINS (2001:187), descreve a essência do custo de oportunidade nas empresas:

"Na empresa, toda vez que existirem problemas de escolha entre várias alternativas de ação, estará presente o conceito de custo de oportunidade. Quando analisa várias alternativas de decisão, o decisor, intuitivamente ou propositadamente, sempre se perguntará se o beneficio a ser obtido, em relação ao sacrifício de recursos correspondentes, será o melhor 
possivel nas circunstâncias em que a decisão está sendo tomada. Essa é a exata essência do conceito de custo de oportunidade".

Percebe-se, dessa forma, que o custo de oportunidade é um conceito indispensável em todas as organizações e que também as IESCEBAS devem considerar esse aspecto quando da apuração do resultado do certificado.

Diante do que foi apresentado, para se obter o custo de oportunidade da alternativa de ter o certificado, deve-se realizar o confronto entre os benefícios gerados pelo mesmo e o benefício que seria obtido pela escolha da alternativa abandonada, ou seja, a cobrança da mensalidade escolar e, nos casos em que existir da prestação de serviços nas clínicas médicas.

Sobre essa questão, MORSE \& ROTH apud BEUREN (1993:4) afirmam que "o custo de oportunidade do uso de um recurso de uma maneira é o recebimento líquido de caixa esperado que poderia ser obtido se o recurso fosse usado na outra ação alternativa mais desejável”.

Exemplificando, suponha-se que em determinada instituição ocorra a seguinte situação:

Benefícios gerados pelo certificado $1.000,00$

Benefícios da alternativa abandonada $1.500,00$

No exemplo, o custo de oportunidade a ser considerado quando da apuração do resultado do certificado, já que a instituição fez a opção pelo mesmo, é de R\$ 1.500,00 (hum mil e quinhentos reais). Em termos de resultado, teríamos um prejuízo para a instituição de $\mathrm{R} \$ 500,00$ (quinhentos reais) em função de ter feito a opção pelo 
certificado.

Nessa visão, comparando-se a alternativa aceita, ou seja, de ter o certificado com a rejeitada não receber pela prestação de serviços, obter-se-ão fortes elementos de análise para avaliar o desempenho da decisão. Esses elementos devem ser objeto de análise pelas IESCEBAS, governo e sociedade.

\subsection{Modelo Proposto de Demonstração do Resultado}

No modelo proposto de Demonstração do Resultado, são utilizados os conceitos de Receitas, Custos e Despesas apresentados.

Ao contabilizar as beneficências como receitas e as contribuições para seguridade social como custos e despesas, constata-se a aplicação do princípio da competência (Anexo A), em que as receitas são confrontadas com as despesas no período em que ocorrem.

A apuração do resultado com o certificado permite à instituição demonstrar o quanto recebeu de benefícios (receitas) e o quanto aplicou em beneficências (custos). Vale ressaltar que, de acordo com a legislação, o saldo apurado deve ser igual a 0 (zero) ou menor que 1 (um), indicando que a instituição aplicou o total dos benefícios recebidos. Se o saldo apurado for igual ou superior a 1 (um), significa que a instituição não aplicou o total dos recursos que deixou de recolher para o governo em contribuições para a seguridade social em beneficências, descumprindo dessa forma a legislação.

O resultado apurado, conforme se pode verificar, é integrado a Demonstração de Resultado. Há que se ressaltar, que a inclusão desse resultado no 
resultado, não modifica o resultado da empresa. Isso ocorre, porque ao contabilizar as Beneficências como receitas da entidade, os encargos com a seguridade social como despesas e a utilização do custo de oportunidade para apurar o resultado do certificado, o saldo do confronto entre esses registros, sempre será igual a zero. Deixando de contabilizar essas receitas e despesas, entretanto contabilizando os custos e despesas que ocorreram para a realização das beneficências, a instituição já contempla, os impactos do certificado e a conseqüente manutenção dos benefícios, no resultado. Dessa forma entretanto, não é demonstrado pela contabilidade qual o valor desses impactos.

A seguir, são apresentados nos itens 4.4 .1 e 4.4 .2 os modelos de demonstração dos resultados contábeis e com o certificado.

\subsubsection{Demonstração do Resultado}

TABELA 21 - Modelo de Demonstração do Resultado

\begin{tabular}{|l|l|}
\hline \multicolumn{2}{|c|}{ DEMONSTRAÇÃO DO RESULTADO } \\
\hline Grupos de Contas & Especificação \\
\hline Receita Operacional Bruta & $\begin{array}{l}\text { Mensalidades escolares, taxa diversas, bolsas de } \\
\text { estudos, serviços de assistência social e outros serviços } \\
\text { prestados à sociedade }\end{array}$ \\
\hline Deduções da Receita & Contribuições sociais incidentes sobre as prestações de \\
\hline
\end{tabular}




\begin{tabular}{|c|c|}
\hline & $s-$ Cofins \\
\hline Operacional & $\begin{array}{l}\text { Receita Operacional Bruta diminuídas as deduções da } \\
\text { receita }\end{array}$ \\
\hline $\begin{array}{l}\text { Custos dos Serviços } \\
\text { Prestados }\end{array}$ & $\begin{array}{l}\text { Salários, encargos sociais, capacitação, atividades de } \\
\text { extensão e demais gastos relacionados à docência }\end{array}$ \\
\hline Lucro Bruto & $\begin{array}{l}\text { Receita Operacional Líquida menos os Custos dos } \\
\text { Serviços Prestados }\end{array}$ \\
\hline Despesas Operacionais & $\begin{array}{l}\text { Despesas administrativas, resultado financeiro e } \\
\text { despesas com provisões }\end{array}$ \\
\hline $\begin{array}{l}\text { Outras Receitas } \\
\text { Despesas Operacionais }\end{array}$ & $\begin{array}{l}\text { Receitas e despesas que não são objeto da instituição, } \\
\text { mas que em função da atividade ocorrem } \\
\text { constantemente. Exemplo: aluguéis }\end{array}$ \\
\hline Resultado Operacional & $\begin{array}{l}\text { Resultado da atividade principal, comparando-se as } \\
\text { receitas com os custos e despesas operacionais }\end{array}$ \\
\hline $\begin{array}{l}\text { Resultado } \\
\text { Operacional }\end{array}$ & $\begin{array}{l}\text { Doações para custeio, resultado da alienação do ativo } \\
\text { imobilizado }\end{array}$ \\
\hline $\begin{array}{l}\text { Resultado Antes da } \\
\text { C.Social }\end{array}$ & $\begin{array}{l}\text { Resultado apurado antes do cálculo da Contribuição } \\
\text { Social }\end{array}$ \\
\hline Contribuição Social & $\begin{array}{l}\text { Contribuição para a seguridade social de acordo com } \\
\text { Art. } 23 \text { da Lei } \mathrm{n}^{\mathrm{o}} 8.212 \text {. }\end{array}$ \\
\hline $\begin{array}{l}\text { Resultado Antes do } \\
\text { Certificado }\end{array}$ & Resultado apurado sem os impactos do certificado \\
\hline Resultado com certificado & $\begin{array}{l}\text { Resultado apurado com o certificado de entidade } \\
\text { beneficente de assistência social, comparando-se as } \\
\text { receitas (benefícios recebidos) com os custos }\end{array}$ \\
\hline
\end{tabular}




\begin{tabular}{|l|l|}
\hline & (beneficências realizadas) \\
\hline Resultado do Exercício & Resultado do período, com os impactos do certificado \\
\hline
\end{tabular}

\subsubsection{Demonstração do Resultado com Certificado}

O modelo proposto, demonstra as receitas e custos ocorridos em determinado período, em função da instituição possuir o certificado de entidade beneficente de assistência social. Há que se ressaltar, que o modelo contempla apenas os valores tangíveis, não sendo considerados, dessa forma, valores intangíveis.O resultado positivo indica que a instituição não cumpriu a legislação, estando sujeita à perda do certificado, e, conseqüentemente, do direito de usufruir os benefícios. O resultado negativo significa que a instituição aplicou mais recursos em beneficências do que recebeu de benefícios. Essa situação demonstra o quanto realmente a instituição praticou de filantropia, haja vista não poder considerar como filantropia o valor aplicado em beneficências com recursos da própria sociedade, ou seja, os valores não repassados pelo governo.

Abaixo é apresentado o modelo de demonstração do resultado com certificado.

TABELA 22 - Modelo de Demonstração do Resultado com Certificado DEMONSTRAÇÃO DO RESULTADO COM CERTIFICADO

\begin{tabular}{|l|l|}
\hline Receitas do Certificado & São considerados como receitas para fins de apuração \\
\hline
\end{tabular} 


\begin{tabular}{|l|l|}
\hline & $\begin{array}{l}\text { do resultado com o certificado as contribuições para a } \\
\text { seguridade social (INSS, Cofins e CSLL). }\end{array}$ \\
\hline Custos do Certificado & As bolsas de estudos e a assistência social prestada \\
pelas IESCEBAS à sociedade são consideradas como \\
custos.
\end{tabular}

Para fins de apuração do resultado com o certificado, estão sendo utilizados os conceitos de custo de oportunidade, em que os custos (bolsas de estudo e assistência social) são a alternativa abandonada, e os benefícios são resultado da decisão tomada pela empresa.

De acordo com MAURO (1991:177):

"o mercado se apresenta como o ponto de definição do valor dos itens transacionados, visto que os preços ali praticados induzem o produtor à venda e o comprador a compra, constituindo-se, sempre que possivel, viável e factivel na alternativa mais adequada a ser adotada como parâmetro de valor".

Apurar os resultados com base no custo de oportunidade, significa utilizar:

a) Bolsas de Estudo - valores de mensalidade praticados no mercado pela instituição para os respectivos cursos; 
b) Assistência Social - valores praticados no mercado pela prestação de serviços nas diversas áreas da saúde, utilizando-se como base a tabela de preços editada pelos conselhos regionais da respectiva área de atuação;

c) Benefícios - valores deixados de recolher para a seguridade social a título de: INSS, Cofins e CSLL, ou seja, as despesas que a empresa teria caso não tivesse os benefícios. Os valores descontados dos funcionários a título de INSS, deverão ser recolhidos normalmente aos cofres do governo.

\subsection{Proposta de Lançamentos Contábeis}

a) Contabilização da Obrigação - à medida que a instituição realize receitas, constitui-se uma obrigação, ou seja, de aplicar pelo menos $20 \%$ (vinte por cento) do valor da receita em gratuidades. Essa obrigação gera um direito para a instituição de não recolher o mesmo valor para a seguridade social.

Contribuições Sociais a Utilizar (Ativo)

a Beneficências a Realizar (Passivo)

b) Contabilização das Gratuidades/Beneficências _ - realizando gratuidades/beneficências, ou seja, dando bolsas de estudos aos alunos ou prestando atendimentos assistenciais à população carente, a 
instituição contabiliza esses valores como receita da sua atividade, utilizando-se como parâmetro o preço de transferência baseado no custo de oportunidade, tendo como contrapartida, a conta do Passivo onde está registrada a sua obrigação de prestar esse serviço. Registra-se, também, esse valor em uma conta de resultado com custo do certificado, com a finalidade de apurar o resultado do mesmo, visto que se trata de um sacrifício da instituição para a manutenção dos benefícios, tendo como contrapartida uma conta de Passivo, com a finalidade de evidenciar o saldo da obrigação.

Gratuidades/Beneficências a Realizar (Passivo)

a Bolsas de Estudo (Receita)

Gratuidades/Beneficências a Realizar (Passivo)

a Assistência Social (Receita)

Custos do Certificado

a Beneficências Realizadas (Passivo)

c) Contabilização dos Benefícios - Os benefícios INSS, Cofins e CSLL não recolhidos ao governo são registrados como custo ou despesa dependendo da sua natureza, tendo como contrapartida, conta do Ativo. Também são registrados como receita, com a finalidade de apurar-se o resultado com o certificado, tendo como contrapartida conta do Ativo, com o objetivo de 
evidenciar o saldo que a instituição possui de benefícios.

Seguridade Social (Custo ou Despesa)

a Contribuições Sociais a Utilizar (Ativo)

Seguridade Social Utilizada (Ativo)

a Receita do Certificado

d) Encerramento das Contas Patrimoniais - $\mathrm{O}$ encerramento das contas patrimoniais é efetuado, porque os saldos não são transferidos para o próximo exercício.

1) Saldo de Beneficências maior que Seguridade Social

Beneficências Realizadas (Passivo)

a Seguridade Social Utilizada (Ativo)

Beneficências Realizadas (Passivo)

a Seguridade Social a Utilizar (Ativo)

2) Saldo de Beneficências menor que Seguridade Social

Beneficências Realizadas (Passivo)

a Seguridade Social Utilizada (Ativo) 
Beneficências a Realizar (Passivo)

a Seguridade Social a Utilizada (Ativo)

As contas Beneficências Realizadas e Seguridade Social são confrontadas, sendo que o saldo se credor é transferido para a conta Seguridade Social a Utilizar, e quando inverso, ou seja, devedor é transferido para a conta Beneficências a Realizar. Isso significa que, quando a instituição tem saldo credor, ela realizou mais beneficências do que usufruiu de benefícios, sendo que, quando o saldo é devedor, ocorre o contrário, ou seja, a instituição obteve mais benefícios do que aplicou em beneficências.

Exemplificando, suponha-se que em determinada instituição ocorra a seguinte situação:

Receitas $100.000,00$

Custos e Despesas ................................................60.000,00

Beneficências realizadas ............................................21.000,00

Seguridade Social .................................................. 15.000,00

De acordo com a proposta apresentada, teríamos os seguintes lançamentos contábeis:

a) Caixa

a Receitas com mensalidades

TABELA 23 - Contabilização da Receita BALANÇO PATRIMONIAL 


\begin{tabular}{|lr|ll|}
\hline ATIVO & PASSIVO & \\
Caixa & $100.000,00$ & & \\
& & P. LÍQUIDO & \\
& & Resultado do Período & $100.000,00$ \\
Total Ativo & $100.000,00$ & Total Passivo + PL & $100.000,00$ \\
\hline
\end{tabular}

b) Custos e Despesas

a Caixa $60.000,00$

TABELA 24 - Contabilização dos Custos e Despesas

\begin{tabular}{|c|c|c|c|}
\hline \multicolumn{4}{|c|}{ BALANCO PATRIMONIAL } \\
\hline ATIVO & & PASSIVO & \\
\hline \multirow[t]{3}{*}{ Caixa } & $40.000,00$ & & \\
\hline & & P. LÍQUIDO & \\
\hline & & Resultado do Período & $40.000,00$ \\
\hline Total Ativo & $40.000,00$ & Total Passivo + PL & $40.000,00$ \\
\hline
\end{tabular}

c) Seguridade Social a Utilizar (Ativo)

a Beneficências a Realizar (Passivo) $20.000,00$

\section{TABELA 25 - Contabilização da Obrigação}




\begin{tabular}{|lr|lll|}
\hline \multicolumn{5}{|c|}{ BALANÇO PATRIMONIAL } \\
\\
ATIVO & $40.000,00$ & PASSIVO & \\
Caixa & Beneficências & a & Realizar \\
Seguridade Social a Utilizar & $20.000,00$ & $20.000,00$ & \\
& & P. LÍQUIDO & \\
Total Ativo & $60.000,00$ & Resultado do Período & $40.000,00$ \\
& & Total Passivo + PL & $60.000,00$ \\
& & & \\
\hline
\end{tabular}

d) Seguridade Social (Custos ou Despesas)

a Seguridade Social a Utilizar $15.000,00$

TABELA 26 - Contabilização das despesas

\begin{tabular}{|lr|lll|}
\hline \multicolumn{5}{|c|}{ BALANÇO PATRIMONIAL } \\
\hline ATIVO & $40.000,00$ & PASSIVO & \\
Caixa & Beneficências & a & Realizar \\
Seguridade Social a Utilizar & $5.000,00$ & $20.000,00$ & \\
& & P. LÍQUIDO & \\
Total Ativo & $45.000,00$ & Resultado do Período & $25.000,00$ \\
& & Total Passivo + PL & $45.000,00$ \\
& & & \\
& & & \\
\end{tabular}

e) Seguridade Social Utilizada 
a Receitas do Certificado

$15.000,00$

TABELA 27 - Contabilização dos benefícios

\begin{tabular}{|lr|lll|}
\hline \multicolumn{5}{|c|}{ BALANÇO PATRIMONIAL } \\
\hline ATIVO & $40.000,00$ & Peneficências & a & Realizar \\
Caixa & $5.000,00$ & $20.000,00$ & \\
Seguridade Social a Utilizar & Stilizada & P. LÍQUIDO & \\
Seguridade & Social & & Resultado do Período & $40.000,00$ \\
$15.000,00$ & & $60.000,00$ & Total Passivo + PL & $60.000,00$ \\
Total Ativo & & & & \\
\hline
\end{tabular}

f) Beneficências a Realizar .

$.20 .000,00$

Seguridade Social a Utilizar $1.000,00$

a Receitas com Beneficências

$.21 .000,00$

TABELA 28 - Contabilização das beneficências

\begin{tabular}{|lr|lr|}
\hline \multicolumn{4}{|c|}{ BALANÇO PATRIMONIAL } \\
\hline ATIVO & $40.000,00$ & PASSIVO & \\
Caixa & & Beneficências a Realizar & 0,00 \\
Seguridade Social a Utilizar & $6.000,00$ & P. LÍQUIDO & \\
Seguridade Social Utilizada & $15.000,00$ & Resultado do Período & $61.000,00$ \\
Total Ativo & $61.000,00$ & Total Passivo + PL & $61.000,00$ \\
\hline
\end{tabular}

g) Custos do Certificado

a Beneficências Realizadas $21.000,00$ 
TABELA 29 - Contabilização dos custos do certificado

\begin{tabular}{|lr|lr|}
\hline \multicolumn{4}{|c|}{ BALANÇO PATRIMONIAL } \\
\hline ATIVO & $40.000,00$ & Peneficências a Realizar & 0,00 \\
Caixa & $6.000,00$ & Beneficências Realizadas & $21.000,00$ \\
Seguridade Social a Utilizar & & PASSIVO & \\
Seguridade Social Utilizada & $15.000,00$ & P. LÍQUIDO & \\
& & Resultado do Período & $40.000,00$ \\
& & & \\
Total Ativo & $61.000,00$ & Total Passivo + PL & $61.000,00$ \\
\hline
\end{tabular}

h) Beneficências Realizadas $.21 .000,00$

a Seguridade Social Utilizadas $15.000,00$

a Seguridade Social a Utilizar. $6.000,00$

TABELA 30 - Contabilização do encerramento

\begin{tabular}{|lr|lr|}
\hline \multicolumn{4}{|c|}{ BALANÇO PATRIMONIAL } \\
\hline ATIVO & $40.000,00$ & PASSIVO & \\
Caixa & 0,00 & Beneficências a Realizar & 0,00 \\
Seguridade Social a Utilizar & 0,00 & P. LÍQUIDO Realizadas & 0,00 \\
Seguridade Social Utilizada & & Resultado do Período & $40.000,00$ \\
& & Total Passivo + PL & $40.000,00$ \\
& $40.000,00$ & & \\
\hline
\end{tabular}

Receitas com Mensalidades
Caixa

Caixa
Custos e Despesas 

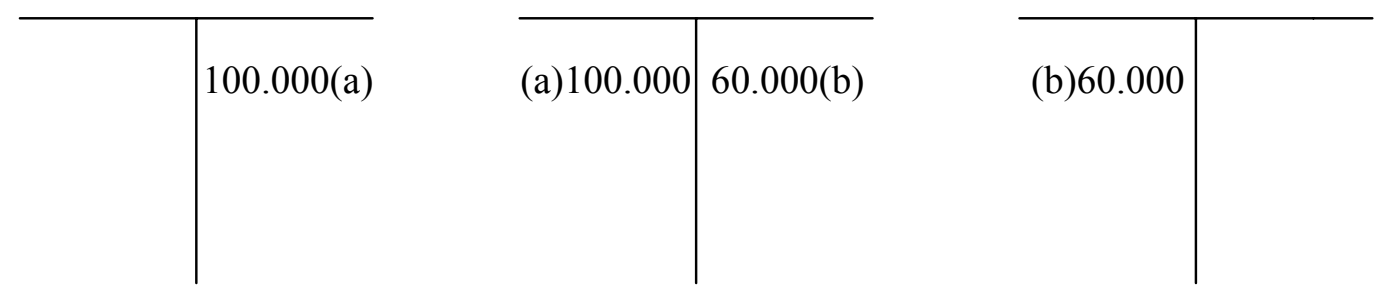

Seguridade Social

a Utilizar

\begin{tabular}{l|r}
\hline (c) 20.000 & $15.000(\mathrm{~d})$ \\
(f) 1.000 & $6.000(\mathrm{~h})$
\end{tabular}

Seguridade Social

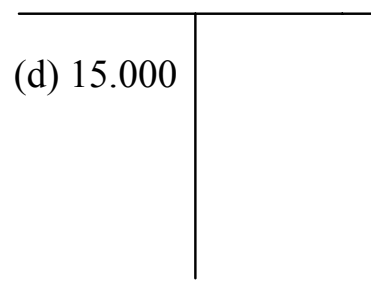

Receita do Certificado

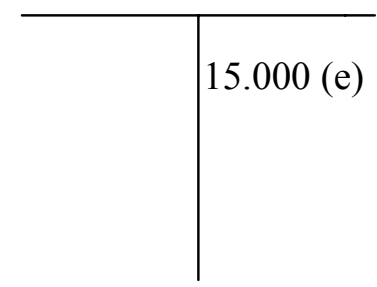

Custo do

Certificado

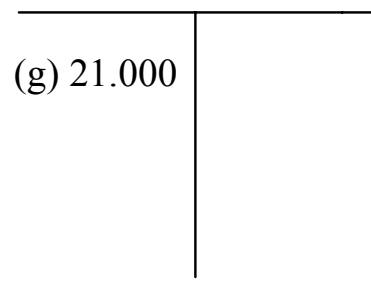

Beneficências

a Realizar

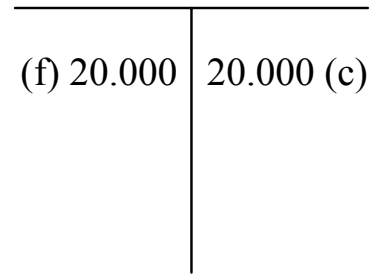

Seguridade Social

Utilizada

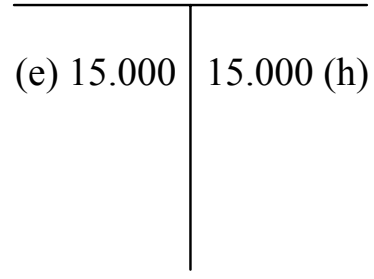

Receitas com

Beneficências

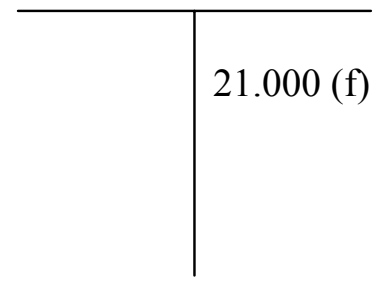

Beneficências

Realizadas

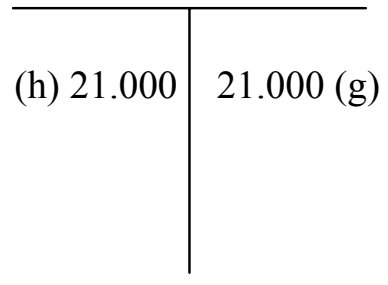


TABELA 31 - Aplicação do Modelo de Demonstração do Resultado

\begin{tabular}{|l|r|}
\hline \multicolumn{2}{|c|}{ DEMONSTRAÇÃO DO RESULTADO } \\
\hline Receita Total & $\mathbf{1 2 1 . 0 0 0 , 0 0}$ \\
\hline Mensalidades Escolares & $100.000,00$ \\
\hline Atividades Beneficentes & $21.000,00$ \\
\hline Custos e Despesas & $\mathbf{( 7 5 . 0 0 0 , 0 0 )}$ \\
\hline Custos e Despesas & $60.000,00$ \\
\hline Seguridade Social & $15.000,00$ \\
\hline Resultado Antes do Resultado do Certificado & $\mathbf{4 6 . 0 0 0 , 0 0}$ \\
\hline Resultado do Certificado & $\mathbf{( 6 . 0 0 0 , 0 0}$ \\
\hline Receitas do Certificado & $15.000,00$ \\
\hline Custos do Certificado & $21.000,00$ \\
\hline Resultado do Exercício & $\mathbf{4 0 . 0 0 0 , 0 0}$ \\
\hline
\end{tabular}

O resultado do exemplo mostra que foram investidos $\mathrm{R} \$ 6.000,00$ (seis mil reais) a mais do que a instituição obteve de benefícios, entretanto, cumpriu-se com a 
obrigação de aplicação de pelo menos $20 \%$ (vinte por cento) da receita em beneficências, haja vista que o total da receita foi de $\mathrm{R} \$ 100.000,00$ (cem mil reais). Constata-se conforme já comentado anteriormente, que o resultado da instituição é o mesmo caso a instituição não se utilize dos conceitos apresentados na proposta. Quando a empresa não contabiliza as receitas com beneficências e os custos e despesas com a seguridade social, já reconhece no resultado o sacrifício de R\$ $6.000,00$ (seis mil reais) apurado no exemplo, justificando dessa forma o resultado ser igual.

\subsection{Considerações Finais}

De acordo com a proposta, é possível o acompanhamento por parte dos gestores de como está a situação da instituição, comparando-se os benefícios usufruídos com as beneficências realizadas, bem como se está atendendo o percentual estabelecido em lei.

O modelo de demonstração de resultado reconhece as receitas e despesas de acordo com os princípios fundamentais de Contabilidade, principalmente no que diz respeito ao princípio da competência. O modelo permite que a instituição verifique como seria o resultado sem o certificado, e quais os impactos do mesmo no patrimônio da entidade.

O modelo de demonstração de resultado com certificado utiliza-se dos conceitos de custo de oportunidade para apurar o resultado do período. São demonstrados o quanto a instituição recebeu de benefícios (receitas) e o quanto teve que sacrificar (custos) para ter esses benefícios.

O resultado com o certificado permite demonstrar para os gestores, governo 
e a sociedade, se a instituição está ou não fazendo filantropia, e se os recursos recebidos (contribuições para seguridade social) estão sendo aplicados de acordo com a legislação. 


\section{CAPÍTULO 5 - ANÁLISES DAS DEMONSTRAÇÕES CONTÁBEIS}

Procurando verificar qual o procedimento adotado pelas IESCEBAS quando da elaboração das demonstrações contábeis, realizamos estudo das demonstrações contábeis da Universidade Católica Dom Bosco - UCDB e da Pontifícia Universidade Católica do Rio de Janeiro - PUC/Rio.

As instituições selecionadas são católicas, comunitárias e administradas por religiosos. Ambas atuam no mesmo segmento, com pequenas diferenças que poderão ser percebidas ao longo do estudo.

O objetivo do estudo é verificar a uniformidade dos procedimentos contábeis adotados, se estão de acordo com a teoria contábil, com as normas brasileiras de Contabilidade e a legislação aplicável a essas instituições. Por meio de análise da estrutura das demonstrações e uma comparação entre os procedimentos adotados na elaboração das demonstrações contábeis, busca-se constatar se a Contabilidade dessas instituições apuram e evidenciam os impactos patrimoniais e econômicos gerados pelo CEBAS.

Os dados foram coletados junto ao setor contábil das referidas instituições, sendo que na UCDB foram coletados pessoalmente e no caso da PUC/Rio foram enviados pela contadora por meio eletrônico. 
Realiza-se, também, a aplicação do modelo proposto utilizando-se as informações das demonstrações contábeis das instituições objeto de estudo, com a finalidade de apurar e evidenciar os resultados e também testar o modelo proposto.

Por fim, apresenta-se sugestão para aperfeiçoamento da Norma Brasileira de Contabilidade aplicada a essas instituições.

Em termos metodológicos, objetiva-se verificar os procedimentos adotados pelas instituições objeto de estudo, na apuração e evidenciação dos impactos patrimoniais e econômicos gerados pelo CEBAS.

\subsection{UCDB - Histórico e Caracterização}

A Universidade Católica Dom Bosco tem sua origem na Faculdade Dom Aquino de Filosofia, Ciências e Letras, instituída em Campo Grande no ano de 1961, pela Missão Salesiana de Mato Grosso - MSMT, iniciando, assim, o ensino superior em Mato Grosso.

Sua expansão, para atender às necessidades da comunidade regional, deu origem às Faculdades Unidas Católicas de Mato Grosso que foram reconhecidas como Universidade em 27 de outubro de 1993 - Portaria No 1.547/93 do Ministério da Educação e do Desporto.

A finalidade da UCDB, expressa no Art. $5^{\circ}$ do seu Estatuto, é "formar profissionais competentes, cidadãos honestos, cristãos conscientes e comprometidos” (São João Bosco). São finalidades em intrínseca relação com os princípios e fins da educação nacional, expressos no Art. $2^{\circ}$ da atual LDB, que contempla o pleno desenvolvimento do educando, seu preparo para o exercício da 
cidadania e sua qualificação para o trabalho. Para a UCDB, que é uma universidade comunitária, católica e salesiana, preparar para a cidadania e qualificar para o trabalho é conseqüência de sua finalidade transcendental de formar bons cristãos e honestos cidadãos.

Na dinâmica dos seus cursos, a preocupação maior é concretizar o perfil de um profissional que, inspirado nos princípios evangélicos, seja competente, crítico em seu saber e comprometido com o seu tempo e a realidade global da sociedade, conforme está expresso no documento que trata desse assunto: (Relatório/UCDB N 2, 1993:6).

A Universidade está instalada em um campus construído numa área de 789 mil metros quadrados e dispõe de uma reserva florestal de 39 hectares. Oferece à comunidade 31 cursos de graduação distribuídos nas áreas de Ciências Biológicas e da Saúde, Ciências Sociais Aplicadas e Ciências Exatas e da Terra, 30 cursos de Pós-Graduação "lato sensu” e na Pós-Graduação "stricto sensu", possui aproximadamente 9.000 alunos distribuídos entre os cursos de graduação e pósgraduação .

Procura estar sempre e cada vez mais, integrada à comunidade regional, mediante o estudo e a identificação dos problemas e a proposta de alternativas para sua solução. Vem, ainda, criando espaços para programas abertos à comunidade, como é o caso dos programas voltados à terceira idade e a comemoração da semana dos povos indígenas que já faz parte do seu calendário.

\subsection{PUC/Rio - Histórico e Caracterização}

A Pontifícia Universidade Católica - RJ tem sua origem nas Faculdades 
Católicas de Filosofia e Direito, instituída no Rio de Janeiro, no ano de 1940, pela Sociedade Civil Faculdades Católicas, iniciando, assim, o ensino superior privado no país.

Seu primeiro Reitor, Padre Leonel Franca, S.J., apresentou, como essencial para a instituição, a busca dos valores humanos e da ética cristã:

"À multiplicidade das funções universitárias, o cristianismo infunde o seu espirito de unidade, de harmonia, de coerência interior, vinculando-as todas numa solidariedade orgânica que é a resposta às exigências de integridade e totalidade da vida. Aqui as disciplinas não se desenvolvem como membros desarticulados de um organismo. A formação do homem é integral."

Em dezembro de 1942, o Presidente Getúlio Vargas assinou os decretos nº 10.984 e 10.985 reconhecendo oficialmente as Faculdades Católicas de Filosofia e Direito. Em 15 de janeiro de 1946, através do decreto $\mathrm{n}^{\circ}$ 8.861, receberam autorização para constituir uma Universidade, tendo recebido, em 20 de janeiro de 1947, da Santa Sé, o título de Universidade Pontifícia.

Sua missão, segundo o seu estatuto, “é o de promover a excelência no ensino, na pesquisa aplicada e no desenvolvimento científico, buscando sempre contribuir para a formação de profissionais sintonizados com o perfil de cidadãos críticos e conscientes.”

O resultado dessa meta é formar profissionais com capacidade para exercerem os mais elevados cargos de liderança, seja na esfera pública ou privada, bem como especialistas e técnicos preparados para participarem ativamente do processo de desenvolvimento do país.

A Universidade está instalada em um campus construído numa área de 
$70.568,69$ metros quadrados numa área de 104.140,33 m2. Oferece à comunidade 24 cursos de graduação distribuídos nas áreas de Ciências Biológicas e da Saúde, Ciências Sociais Aplicadas, Ciências Exatas e da Terra e Teologia e Ciências Humanas, 26 cursos de Pós-Graduação "lato sensu" e, na Pós-Graduação "stricto sensu", possui aproximadamente 11.500 alunos, distribuídos entre os cursos de graduação e pós-graduação.

Através de diversos programas e ações, procura estar sempre e cada vez mais, integrada à comunidade regional, procurando levar principalmente à população carente melhor qualidade de vida e um melhor aprimoramento profissional, dando a cada um uma maior consciência social, independente da carreira que escolheu.

\subsection{Balanço Patrimonial}

O Balanço Patrimonial tem por finalidade apresentar a posição financeira de determinada entidade em um determinado momento, sendo, portanto, uma posição estática.

Conforme o Art. 178 da Lei $n^{\circ}$ 6404/76, "no balanço, as contas serão classificadas segundos os elementos do patrimônio que registrem, e agrupadas de modo a facilitar o conhecimento e a análise da situação financeira da companhia”.

Apesar das IESCEBAS não estarem obrigadas a seguir a referida Lei, o Conselho Federal de Contabilidade, através da NBC T 10.19, aprovou a utilização da estrutura patrimonial estabelecida na Lei $n^{\circ}$ 6404/76, apenas com algumas alterações.

Apresentamos a seguir os Balanços Patrimoniais das instituições objeto de análise. 
TABELA 32 - Balanços Patrimoniais UCDB

MSMT - UNIVERSIDADE CATÓLICA DOM BOSCO BALANÇO PATRIMONIAL ENCERRADO EM 31 DE DEZEMBRO

\begin{tabular}{|c|c|c|}
\hline ATIVO & 2001 & 2000 \\
\hline \multicolumn{3}{|l|}{ CIRCULANTE } \\
\hline \multicolumn{3}{|l|}{ DISPONIVEL } \\
\hline CAIXA GERAL & $4.246,23$ & $4.086,08$ \\
\hline BANCOS CONTA MOVIMENTO & $80.351,11$ & $128.959,66$ \\
\hline BANCOS CONTA CONVÊNIO & $86.131,70$ & $46.052,44$ \\
\hline BANCOS CONTA POUPANÇA & 0,00 & $9.986,10$ \\
\hline APLICAÇÕES COM LIQUIDEZ IMEDIATA & $5.282 .620,82$ & $5.950 .632,91$ \\
\hline TOTAL DISPONÍVEL & $5.453 .349,86$ & 6.139.717,19 \\
\hline \multicolumn{3}{|l|}{ DIREITOS } \\
\hline CRÉDITOS A RECEBER & $7.681 .836,48$ & $5.292 .733,92$ \\
\hline ADIANTAMENTOS & 2.031.529,28 & $1.264 .341,23$ \\
\hline EMPRÉSTIMOS & $1.412 .517,87$ & $1.527 .990,40$ \\
\hline ANTECIPAÇÕES TRABALHISTAS E FISCAIS & $2.994,85$ & 183,41 \\
\hline CONVÊNIOS & $13.072,80$ & $7.378,08$ \\
\hline TOTAL DIREITOS & $11.141 .951,28$ & $8.092 .627,04$ \\
\hline ESTOQUES & $225.351,27$ & $22.020,01$ \\
\hline TOTAL ESTOQUES & $225.351,27$ & $22.020,01$ \\
\hline TOTAL ATIVO CIRCULANTE & $16.820 .652,41$ & $14.254 .364,24$ \\
\hline \multicolumn{3}{|l|}{ REALIZÁVEL A LONGO PRAZO } \\
\hline CRÉDITOS A RECEBER & $1.938 .516,51$ & $1.951 .160,77$ \\
\hline (-) PROVISÃO PARA DEVEDORES DUVIDOSOS & $(205.524,05)$ & 0,00 \\
\hline TOTAL REALIZÁVEL A LONGO PRAZO & $1.732 .992,46$ & $1.951 .160,77$ \\
\hline \multicolumn{3}{|l|}{ PERMANENTE } \\
\hline INVESTIMENTO & $4.845,58$ & 4845,58 \\
\hline \multicolumn{3}{|l|}{ IMOBILIZADO } \\
\hline MÓVEIS E UTENSÍLIOS & $1.246 .422,89$ & $952.853,23$ \\
\hline MÁQUINAS E EQUIPAMENTOS & $7.160 .572,05$ & $5.605 .674,49$ \\
\hline INSTALAÇÕES & $58.833,32$ & $58.923,65$ \\
\hline VEÍCULOS & $400.764,62$ & $296.764,62$ \\
\hline CONSTRUÇÕES EM ANDAMENTO & 8.634.271,71 & $5.642 .091,48$ \\
\hline SEMOVENTES & $960.209,00$ & $71.251,00$ \\
\hline EQUIPAMENTOS PARA ESCOLA & 1.575.171,97 & $1.026 .512,04$ \\
\hline BIBLIOTECA & $2.261 .145,58$ & $1.619 .821,09$ \\
\hline (-) DEPRECIAÇÕES ACUMULADAS & $(4.160 .346,98)$ & $(2.933 .055,77)$ \\
\hline TOTAL PERMANENTE & $18.137 .044,16$ & $12.340 .835,83$ \\
\hline \multicolumn{3}{|l|}{ DIFERIDO } \\
\hline \multicolumn{3}{|l|}{ EMPENHO PARA INVESTIMENTOS FUTUROS } \\
\hline PROJETOS DE CONSTRUÇÕES & 0,00 & $2.540 .000,00$ \\
\hline TOTAL DIFERIDO & 0,00 & $2.540 .000,00$ \\
\hline TOTAL ATIVO & $36.690 .689,03$ & 31.086.360,84 \\
\hline \multicolumn{3}{|l|}{ COMPENSAÇÃO } \\
\hline BOLSAS DE ESTUDO & $3.523 .395,20$ & 3.206.773,79 \\
\hline ATENDIMENTO E SERVIÇOS BENEFICENTES & $3.833 .743,55$ & $1.290 .026,04$ \\
\hline OUTRAS ATIVIDADES BENEFICENTES & $111.534,48$ & 0,00 \\
\hline TOTAL COMPENSAÇÃO & $7.468 .673,23$ & $4.496 .799,83$ \\
\hline
\end{tabular}




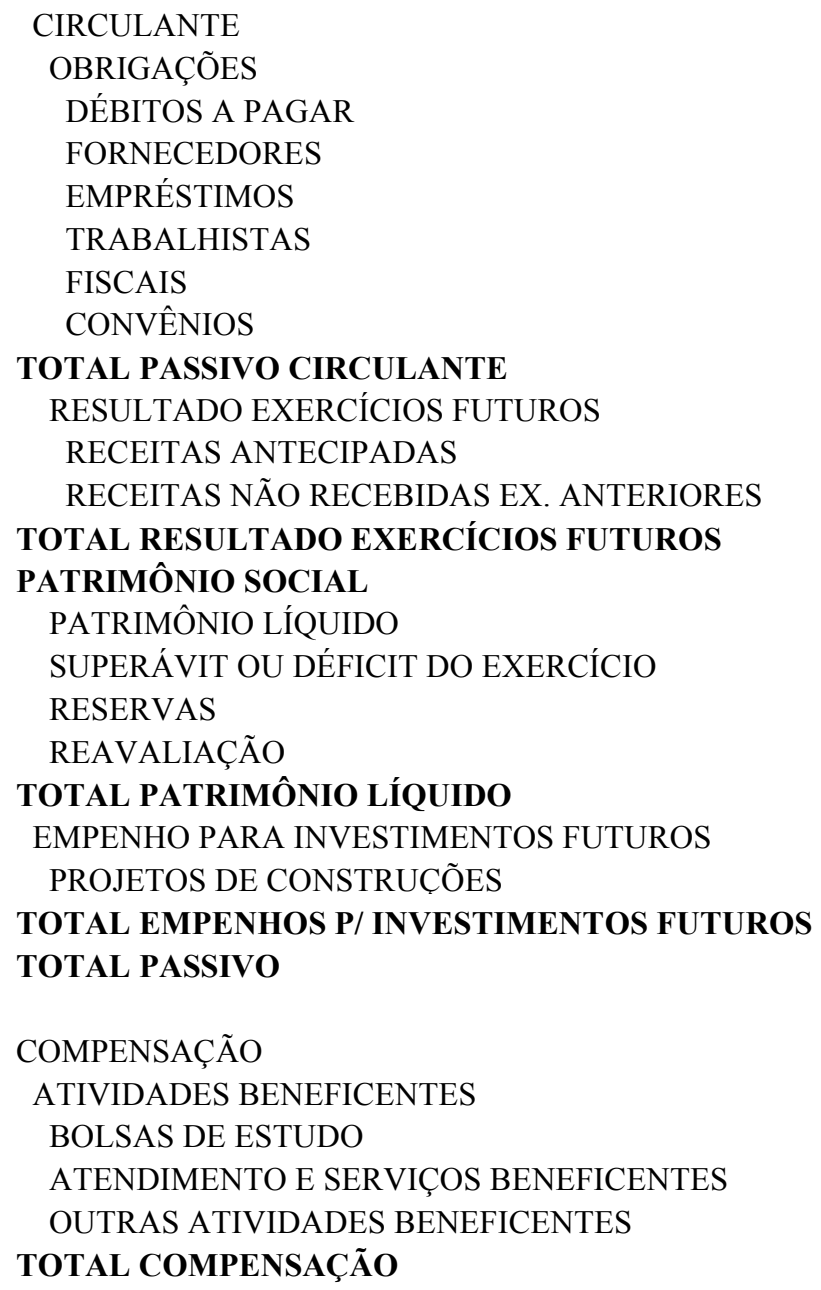

$\begin{array}{rr}0,00 & 3,00 \\ 256.142,74 & 1.120 .004,39 \\ 51.526,58 & 287.079,09 \\ 1.639 .051,11 & 1.737 .986,58 \\ 13.289,97 & 23.789,27 \\ 8.612,25 & 11.304,43 \\ 1.968 .622,65 & 3.180 .166,76 \\ & \\ 2.283 .708,19 & 1.988 .104,45 \\ 1.610 .772,33 & 3.938 .778,54 \\ 3.894 .480,52 & 5.926 .882,99 \\ & \\ 19.217 .574,49 & 12.792 .447,35 \\ 7.180 .148,92 & 6.038 .739,57 \\ 4.200 .000,00 & 0,00 \\ 234.708,03 & 612.969,75 \\ 30.832 .431,44 & 19.444 .156,67 \\ & \\ 0,00 & 2.540 .000,00 \\ 0,00 & 2.540 .000,00 \\ 36.695 .534,61 & 31.091 .206,42 \\ & \\ 7.468 .673,23 & 4.496 .799,83\end{array}$


TABEL A33 - Balanços Patrimoniais PLCRio

FACUDADESCATÓUCAS-PUCRIO

BALANÇOPATIRIMONALEM31 DEDEZEMBRO

(EmReais-RS)

ATIVO
OROUANIE
Caixae Bancos
Aplicaçóes Financeiras
Mensalidades, Serviços e Convênios a Receber
Mensalidades Antecipadas
Prov. p p Devedores Dridosos
Adiantamentos a Funcionários
Adiantamentos Diversos
Otrros Creditos
Almoxarifado
Despesas doExercício Seguinte

REAIZÁVLALONGOPRAZO

Depósitos Judiciais

PERMANENIE

Imbbilizado

Depreciação Aamulada

TOTALDOAIIVO

COMPENAÇÃOO

Gratuidades Educacionais

Outras Atividades Beneficentes

Immidades Quota Patronal

\begin{tabular}{|c|c|}
\hline 2001 & 2000 \\
\hline 636.725 & 424.472 \\
\hline 28.601 .802 & 22.253 .859 \\
\hline 15.437 .034 & 18.003 .839 \\
\hline$(5.623 .367)$ & (5.103.211) \\
\hline$(4.223 .596)$ & (6.101.798) \\
\hline 1.045 .605 & 1.050 .477 \\
\hline 1.664 .941 & 304.962 \\
\hline 2933.005 & 1.319 .027 \\
\hline 77.027 & 68.283 \\
\hline 33.164 & 303.132 \\
\hline 40.582340 & 32523.042 \\
\hline 3.115 .813 & 4.776 .162 \\
\hline
\end{tabular}

\begin{tabular}{rrr}
$\begin{array}{r}83.367 .193 \\
(29.329 .523)\end{array}$ & & $\begin{array}{r}68.969 .411 \\
(24.008 .089)\end{array}$ \\
\cline { 3 - 3 } 54.037 .670 & & 44.961 .322 \\
\hline & & \\
\hline 97.735 .823 \\
\hline
\end{tabular}

21.951 .178

21.268 .838

$11.008 .190 \quad 13.274 .000$

$17.305 .370 \quad 16.480 .213$ 
PASSIVO

CIRCULANTE

Financiamentos

Fornecedores

Salários a Pagar

Encargos Sociais a Recolher

Impostos a Recolher

Obrigações Educacionais

Convênios Contratados

Bolsas Entidades Externas

Provisão para Ferias

Outras Contas a Pagar

EXIGíVEL A LONGO PRAZO

Financiamentos

Provisão para Contingências

PATRIMÔNIO LÍQUIDO

Patrimônio Social

Superávit do Exercício

TOTAL DO PASSIVO

COMPENSAÇÃO

Gratuidades em Bolsas

Outros Programas de Assistência Social

Imunidades Usufruídas INSS

\begin{tabular}{|c|c|}
\hline $\operatorname{dez} / 01$ & $\operatorname{dez} / 00$ \\
\hline 439.967 & 447.030 \\
\hline 1.695 .281 & 1.802 .959 \\
\hline 3.410 .076 & 3.041 .155 \\
\hline 1.812 .916 & 1.027 .712 \\
\hline 679.977 & 576.234 \\
\hline 595.834 & 505.962 \\
\hline 8.277 .996 & 8.976 .284 \\
\hline 1.586 .318 & 405.895 \\
\hline 10.089 .103 & 8.404 .958 \\
\hline 640.157 & 675.735 \\
\hline 29.227 .625 & 25.863 .924 \\
\hline 3.121 .881 & 3.435 .591 \\
\hline 15.377.369 & 11.096 .029 \\
\hline 18.499 .250 & 14.531 .620 \\
\hline 46.980 .388 & 37.580 .842 \\
\hline 3.028 .560 & 4.284 .140 \\
\hline 50.008 .948 & 41.864 .982 \\
\hline 97.735 .823 & 82.260 .526 \\
\hline
\end{tabular}

21.951 .178

21.268 .838

13.274 .000

11.008 .190

17.305 .370

50.264 .738 
instituições, que serão analisadas abaixo.

\section{a) Ativo Circulante}

- A UCDB adota o procedimento de divisão do grupo da seguinte forma: disponível, direitos e estoques, não utiliza a conta provisão para devedores duvidosos, ferindo, dessa forma, o princípio de competência (Anexo A). O fato gerador da possível perda com clientes, acontece na contratação dos serviços e não quando da sua efetivação. Não aparece no Balanço nenhum saldo de despesas de exercícios seguintes, entretanto, é difícil imaginar que essa situação não ocorra, visto a instituição possuir imobilizados segurados, proceder a assinaturas de revistas, periódicos e outras situações que ocorrem com freqüência.

- A PUC/Rio não utiliza divisão para o grupo, faz a provisão com perdas obedecendo, dessa forma, ao princípio de competência. Os valores recebidos antecipadamente são creditados no Ativo como redutora da conta Mensalidades. Esse fato deveria ser registrado em conta de Passivo como Adiantamento de Clientes, visto não estar vinculado aos valores a receber de mensalidades e sim de serviços a serem executados no futuro.

\section{b) Ativo Realizável a Longo Prazo}

- A UCDB registra, nesse grupo, os valores a receber a longo prazo, bem como os valores não recebidos há mais de 365 (trezentos e sessenta e cinco) dias da data do balanço. Esse procedimento não encontra força na legislação, que diz: "No ativo realizável a longo prazo serão registrados os direitos realizáveis após o término do exercício seguinte." O fato de o direito estar vencido há mais de 365 (trezentos e 
sessenta e cinco) dias não significa que a sua realização só ocorrerá após o exercício seguinte. Verifica-se, nesse grupo, a conta Provisão para Devedores Duvidosos, significando que só existe possibilidades de perda no Longo Prazo.

- A PUC/Rio, nesse grupo, registra os Depósitos Judiciais.

c) Ativo Permanente

- Não há considerações a fazer sobre este grupo, visto estar de acordo com a legislação.

d) Ativo Diferido

- A UCDB utilizou, no ano de 2000, esse grupo para registrar previsão de gastos com investimentos futuros, estando em desacordo com a legislação, que diz: Esses valores poderiam ser registrados em Contas de Compensação.

e) Compensação

- Na UCDB são registradas as bolsas de estudo concedidas, o atendimento à comunidade através das clínicas e outras atividades consideradas beneficentes, porém os custos ocorridos, em função dessas atividades, estão registrados em conta de resultado, contrariando, dessa forma, o princípio da realização da receita e confrontação da despesa.

- A PUC/Rio, além das atividades registradas pela UCDB, também registra os valores não recolhidos ao Instituto Nacional do Seguro Social - INSS, porém, como ocorre com a UCDB, registra os custos em conta de resultados. Esse 
procedimento encontra força na Norma Brasileira de Contabilidade e no Parágrafo Único do Art. $4^{\circ}$ do Decreto 2536, que estabelecem que as instituições devem demonstrar em Notas Explicativas o valor dos benefícios como se devidos fossem, devendo, dessa forma, serem demonstrados os demais benefícios, visto não ser somente a cota patronal do INSS o benefício fiscal dessas instituições.

\section{f) Passivo Circulante}

- A UCDB não realiza a provisão de férias, contrariando, dessa forma, o principio da realização da receita e confrontação da despesa.

- Sobre a PUC/Rio não há considerações a fazer, visto estar de acordo com a legislação.

g) Exigível a Longo Prazo

- No Balanço da UCDB não aparece saldo nesse grupo.

- A PUC/Rio registra as Provisões para Contingências nesse grupo, estando em desacordo com a legislação.

h) Resultado de Exercícios Futuros

- A UCDB registra os valores recebidos antecipadamente nesse grupo, contrariando o entendimento firmado sobre o assunto, visto que existe a possibilidade de devolução dos valores recebidos, quer seja por indeferimento da matrícula ou por desistência do aluno. Registra, também, os valores não recebidos em exercícios anteriores, estando esse fato totalmente em desacordo com a legislação, pois, se é uma receita não recebida, não se trata de resultado futuro. 
- A PUC/Rio não utiliza esse grupo, registrando como já foi comentado anteriormente, os valores recebidos antecipadamente como conta redutora do Ativo Circulante.

i) Patrimônio Líquido ou Patrimônio Social

- No Balanço da UCDB aparecem as contas de Reservas e Reavaliação, o que está correto, porém existe um pequeno problema na estrutura do grupo, visto que denomina de Patrimônio Social e depois totaliza como Patrimônio Líquido. Sobre essa questão a NBC T 10.19 diz:

“10.19.3.2 - Na aplicação das normas contábeis, em especial a NBC T 3, a conta Capital deve ser substituída por Patrimônio Social, integrante do grupo Patrimônio Líquido, e a conta Lucros ou Prejuízos Acumulados por Superávit ou Déficit do Exercício."

Portanto, o correto, de acordo com a norma, é utilizar o grupo como Patrimônio Líquido e, em substituição à conta Capital Social, utiliza-se a conta Patrimônio Social.

- A PUC/Rio não registra as Reservas nesse grupo, sendo registradas no Exigível a Longo Prazo, como já abordado anteriormente. Com relação à questão estrutural, o procedimento adotado está de acordo com a norma.

\subsection{Demonstração do Resultado}

Para IUDÍCIBUS, MARTINS \& GELBCKE (2000:290): “A Demonstração do Resultado do Exercício é a apresentação, em forma resumida, das operações realizadas pela empresa, durante o exercício social, demonstradas de forma a 
destacar o resultado líquido do período”.

O Art. 187 da Lei $n^{\circ}$ 6404/76 estabeleceu a ordem de apresentação das receitas, custos e despesas, para fins de publicação. Vale ressaltar que é através dos princípios contábeis que deve orientar-se a Contabilidade, sendo esses princípios expressos no $\S 1^{\circ}$ do Art. 187 da referida lei, como segue:

“ $\S 1^{\circ} \mathrm{Na}$ determinação do resultado do exercício serão computados:

a) as receitas e os rendimentos ganhos no período, independentemente da sua realização em moeda; e

b) os custos, despesas, encargos e perdas, pagos ou incorridos, correspondentes a essas receitas e rendimentos."

Nota-se que o legislador, ao escrever o citado artigo, basicamente procurou atender ao princípio da competência.

Diante disso, nossa análise se pautará na referida lei, visto que o Conselho Federal de Contabilidade a referendou para as instituições sem fins lucrativos, observando sempre o que estabelece a NBC T 10.19 com relação à Demonstração de Resultado. 
TABELA 34 - Demonstrações dos Resultados UCDB

\section{MSMT - UNIVERSIDADE CATÓLICA DOM BOSCO DEMONSTRAÇÃO DO RESULTADO EM 31 DE DEZEMBRO 2001}

RECEITAS

2000

OPERACIONAIS

PRESTAÇÕES E TAXAS

DOAÇÕES

SUBVENÇÕES

FINANCEIRAS

ALUGUÉIS E ARRENDAMENTOS

OUTRAS RECEITAS OPERACIONAIS

TOTAL OPERACIONAIS

NÃO OPERACIONAIS

REEMBOLSOS

OUTRAS RECEITAS NÃO OPERACIONAIS

TOTAL NÃO OPERACIONAL

TOTAL RECEITAS

DESPESAS

OPERACIONAIS

SALÁRIOS E ENCARGOS

SERVIÇOS PROFISSIONAIS TERCEIROS

SANEAMENTO E ENERGIA

MATERIAIS DE CONSUMO

CAPACITAÇÃO DE PESSOAL

ATIVIDADES DE EXTENSÃO

ADMINISTRATIVAS

ALUGUÉIS E ARRENDAMENTOS

TRIBUTÁRIAS

DEPRECIAÇÕES

MANUTENÇÃO

COMUNICAÇÃO

FINANCEIRAS

LOCOMOÇÃO

PROVISÃO PARA DEVEDORES DUVIDOSOS

OUTRAS DESPESAS OPERACIONAIS

TOTAL DESPESAS OPERACIONAIS

NÃO OPERACIONAIS

DESPESAS GERAIS

ASSISTÊNCIA A SAÚDE

TOTAL DESPESAS NÃO OPERACIONAIS

TOTAL DESPESAS

$\begin{array}{rr}37.879 .828,57 & 31.815 .179,43 \\ 255.112,16 & 154.005,86 \\ 383.246,66 & 352.489,59 \\ 2.867 .941,90 & 1.280 .088,52 \\ 114.848,51 & 58.903,74 \\ 44.678,85 & 27.470,67 \\ 41.545 .656,65 & 33.688 .137,81 \\ & \\ 184.910,73 & 569.418,21 \\ 171.061,01 & 533.984,52 \\ 355.971,74 & 1.103 .402,73 \\ 41.901 .628,39 & 34.791 .540,54 \\ & \\ & \\ 19.130 .531,46 & 20.180 .004,11 \\ 1.877 .972,20 & 1.349 .415,72 \\ 541.074,79 & 538.267,99 \\ 1.120 .210,85 & 1.028 .782,42 \\ 389.794,22 & 351.810,78 \\ 141.294,43 & 317.733,10 \\ 393.079,87 & 904.720,83 \\ 163.313,22 & 176.874,59 \\ 31.894,45 & 129.591,54 \\ 1.579 .425,25 & 1.456 .880,32 \\ 1.682 .078,13 & 673.482,79 \\ 634.214,87 & 414.633,54 \\ 186.245,90 & 162.666,59 \\ 445.496,34 & 414.081,65 \\ 205.524,05 & 0,00 \\ 657.276,55 & 497.909,48 \\ 29.179 .426,58 & 28.596 .855,45 \\ & \\ 242.174,70 & 116.663,78 \\ 33.556,70 & 20.283,34 \\ 275.731,40 & 136.947,12 \\ 29.455 .157,98 & 28.733 .802,57 \\ & \\ (102.758,91) & (4.180,25) \\ (963.562,58) & (14.818,15) \\ (1.066 .321,49) & (18.998,40) \\ & \end{array}$

ALIENAÇÕES E TRANSFERÊNCIAS DE FUNDOS

ALIENAÇÕES DO ATIVO FIXO

$(102.758,91)$

TRANSFERÊNCIAS DE FUNDOS

$(1.066 .321,49)$

$(18.998,40)$

DEMONSTRAÇÃO DO SUPERÁVIT OU DÉFICIT 
TABELA 35 - Demonstrações dos Resultados PUC/Rio

\section{FACULDADES CATÓLICAS - PUC/RIO DEMONSTRAÇÃO DO RESULTADO EM 31 DE DEZEMBRO (Em Reais - R\$)}

\begin{tabular}{|c|c|c|}
\hline & 2001 & 2000 \\
\hline RECEITA OPERACIONAL BRUTA & 117.133 .750 & 106.509 .929 \\
\hline Mensalidades & 79.729 .228 & 72.430 .737 \\
\hline Cursos Periodicos & 12.217 .150 & 11.790 .018 \\
\hline Prest. de Serviços & 8.215 .389 & 8.195 .651 \\
\hline Convênios & 6.318 .304 & 3.599 .309 \\
\hline Contribuições e Doações & 3.175 .642 & 3.345 .761 \\
\hline Patrimoniais & 1.403 .385 & 1.247 .310 \\
\hline Taxas Internas & 1.556 .055 & 1.383 .905 \\
\hline Outras Receitas & 1.826 .282 & 1.232 .685 \\
\hline Ressarcimentos de Projetos Específicos e Outros & 2.692 .315 & 3.284 .553 \\
\hline DESPESAS & $(116.641 .114)$ & $(103.655 .361)$ \\
\hline Pessoal & $(62.931 .790)$ & $(54.655 .281)$ \\
\hline Encargos Sociais & $(16.855 .138)$ & $(16.157 .701)$ \\
\hline Serviços de Terceiros & $(16.054 .794)$ & $(14.143 .128)$ \\
\hline Materiais & $(4.248 .264)$ & (3.364.297) \\
\hline Despesas Gerais & $(6.378 .293)$ & (5.562.094) \\
\hline Impostos e Taxas & $(15.968)$ & (21.844) \\
\hline Depreciações & $(5.321 .433)$ & $(4.867 .061)$ \\
\hline Contingências & $(4.281 .338)$ & (4.386.948) \\
\hline Prov. p/ Devedores Duvidosos & 46.565 & 39.537 \\
\hline Outras Despesas & $(600.661)$ & $(536.544)$ \\
\hline RESULTADO OPERACIONAL & 492.636 & 2.854 .568 \\
\hline RECEITAS FINANCEIRAS & 3.373 .575 & 2.090 .831 \\
\hline DESPESAS FINANCEIRAS & $(837.651)$ & $(661.259)$ \\
\hline SUPERÁVIT DO EXERCÍCIO & 3.028 .560 & 4.284 .140 \\
\hline
\end{tabular}

Assim como ocorreu no Balanço Patrimonial, existem diferenças nos critérios adotados pelas instituições em análise. 


\section{a) Receita Operacional}

- A UCDB registra as receitas financeiras e de aluguéis e arrendamentos nesse grupo. Ambas não são receitas da operação da entidade, devendo as receitas financeiras ser registradas no grupo despesas operacionais, e aluguéis e arrendamentos em outras receitas operacionais.

- A PUC/Rio também registra as receitas patrimoniais nesse grupo, bem como ressarcimentos de projetos, conforme demonstração. Cabe o mesmo comentário feito para a UCDB: a primeira por não ser atividade da instituição locação de imóveis e a segunda por ressarcimento não se tratar de receita.

As duas instituições registram as Doações como receita operacional. Alguns autores defendem que se tratam de ganhos. IUDÍCIBUS (2000:162) define como: “Especificamente, um ganho representa um resultado líquido favorável resultante de transações ou eventos não relacionados às operações normais do empreendimento." As doações podem ter o caráter de capital ou de custeio, sendo que, no caso de capital, como é o caso da doação de um veículo, a norma estabelece que se registre em conta de reserva no Patrimônio Líquido e, em se tratando de doação para custeio, estabelece-se que se registre o fato em conta de resultado. Sobre essa questão IUDÍCIBUS (2000:162) afirma:

"Entretanto, uma doação para reforçar o rendimento corrente de um empreendimento poderia ser considerada como receita extraordinária e não ganho, pois, nesse caso, não existe confronto entre aspectos favoráveis e desfavoráveis."

Diante disso, o procedimento adotado pelas instituições em estudo não está correto. 
b) Receitas Não Operacionais

- A UCDB registra reembolsos como receita não operacional. IUDÍCIBUS, MARTINS \& GELBCKE (2000:315) afirmam que: “somente farão parte dos resultados não operacionais os lucros ou prejuízos na venda ou baixa de bens do Ativo Permanente".

IUDÍCIBUS (2000:165) esclarece que “a Lei n 6404/76 não especifica o que considera receita e despesas não operacionais. Seriam os itens extraordinários ou certas receitas e despesas eventuais do tipo venda de sucata etc? Tudo leva a crer que ambas."

Diante do que foi apresentado como definição de receita e pelas considerações acima apresentadas, conclui-se que a pratica adotada não está correta, visto não possuir características nem de receita e muito menos de não operacional.

- A PUC/Rio não utiliza esse grupo.

c) Despesas

- A UCDB utiliza um nível de detalhamento que confunde o entendimento do leitor. Facilitaria se sintetizasse várias despesas elencadas, como por exemplo: salários e ordenados, serviços profissionais de terceiros, saneamento e energia, materiais de consumo e outras como despesas administrativas. Também não faz a separação do que é custo e despesa.

- A PUC/Rio assim como a UCDB também não faz a separação do que é custo e despesa.

d) Despesas Não Operacionais

- A UCDB contabiliza algumas despesas como não operacionais, esse 
procedimento, conforme visto anteriormente, não encontra amparo na legislação, sendo aplicado de forma incorreta.

- A PUC/Rio não utiliza esse grupo.

e) Alienação e Transferência de Fundos

- Na demonstração da UCDB, verifica-se a existência desse grupo. As alienações conforme visto anteriormente, devem ser registradas no Resultado Não Operacional. Com relação à transferência de fundos, trata-se de recursos que a instituição repassa mensalmente à mantenedora a título de custeio das suas atividades, portanto, trata-se de uma despesa que deve ser contabilizada no grupo operacional.

- A PUC/Rio não utiliza esse grupo.

f) Receitas e Despesas Financeiras

- A UCDB não utiliza esse grupo.

- A PUC/Rio demonstra as receitas e despesas financeiras depois do Resultado Operacional, conforme visto anteriormente somente as alienações do Ativo Permanente é que fazem parte do Resultado Não Operacional, portanto, esse grupo deveria estar incluído no resultado operacional.

\subsection{Aplicação dos Modelos Propostos}

Diante do exposto, apresenta-se a seguir as Demonstrações dos Resultados 
aplicando-se os modelos propostos, utilizando os dados extraídos das Demonstrações dos Resultados da UCDB e PUC/Rio referentes aos exercícios de 2000 e 2001. 


\subsubsection{UCDB}

TABELA 36 - Proposta de Demonstração dos Resultados UCDB

\section{MSMT - UNIVERSIDADE CATÓLICA DOM BOSCO DEMONSTRAÇÃO DO RESULTADO DO PERÍODO DE 01/01 A 31/12}

RECEITA OPERACIONAL BRUTA $2001 \quad 2000$

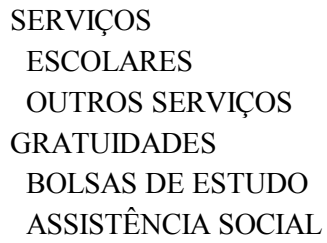

$37.879 .828,57$

$44.678,85$

$3.523 .395,20$

$3.945 .278,03$

45.393.180,65

$1.361 .795,42$

44.031.385,23

17.039.183,65

$12.183 .095,94$

$4.324 .999,06$

$389.794,22$

$141.294,43$

26.992.201,58

14.793.238,86

$17.474 .934,86$

$(2.681 .696,00)$

0,00

$\mathbf{1 1 4 . 8 4 8 , 5 1}$

$114.848,51$

12.313.811,23

$$
\begin{array}{r}
\mathbf{4 3 0 . 9 2 9 , 5 2} \\
809.419,83 \\
(275.731,40) \\
(102.758,91)
\end{array}
$$

12.744.740,75

$1.147 .026,67$

11.597.714,08

RESULTADO ANTES DO CERTIFICADO

RESULTADO COM CERTIFICADO

RECEITAS DO CERTIFICADO

CUSTOS DO CERTIFICADO

RESULTADO DO EXERCÍCIO $\mathbf{- 2 1 7 . 5 6 5 , 1 6}$

7.251.108,07

7.468.673,23

11.380.148,92
31.815.179,43

$27.470,67$

3.206.773,79

1.290.026,04

36.339.449,93

1.090.183,50

$35.249 .266,43$

15.106.983,89

$10.654 .937,28$

$3.782 .502,73$

$351.810,78$

$317.733,10$

20.142.282,54

15.905.591,47

17.023.013,40

$(1.117 .421,93)$

0,00

$\mathbf{5 8 . 9 0 3 , 7 4}$

$58.903,74$

4.295.594,81

899.352,60

$1.040 .479,97$

$(136.947,12)$

$(4.180,25)$

5.194.947,41

$467.545,27$

4.727.402,14

1.311.337,42

$5.808 .137,25$

$4.496 .799,83$

6.038.739,57 


\section{a) Receita Operacional Bruta}

Foram retirados da demonstração de resultado somente os valores a título de prestações e taxas e outras receitas operacionais.

Foram incluídas como receitas de gratuidades os valores com Bolsas de Estudo e Assistência Social contabilizados em Contas de Compensação.

b) Deduções da Receita

Incluída a Cofins por tratar-se de contribuição para seguridade social de acordo com Art. 23 da Lei ${ }^{\circ} 8.212$.

c) Custos dos Serviços Prestados

Não são objeto de análise e estudo deste trabalho os custos dos serviços prestados dessas instituições, entretanto, optou-se por separar alguns custos sem entrar na discussão particular de cada um. Foram incluídos como custos:

- Salários dos Docentes;

- Encargos Sociais incidentes sobre os salários dos docentes: 26,5\% INSS, $8 \%$ FGTS e 1\% PIS;

- Gastos com capacitação de docentes; e

- Gastos com atividades de extensão.

d) Despesas Operacionais

Foram sintetizadas as diversas contas apresentadas na demonstração de resultado em despesas administrativas, conforme quadro abaixo:

\section{TABELA 37 - Despesas Administrativas UCDB}




\begin{tabular}{|c|c|c|}
\hline CONTA & VALOR 2001 & VALOR 2000 \\
\hline Salários e Encargos & $5.850 .956,88$ & $8.566 .122,48$ \\
\hline INSS S/ Salários ${ }^{18}$ & $1.315 .232,16$ & $1.166 .633,78$ \\
\hline Serviços Profissionais Terceiros & $1.877 .972,20$ & $1.349 .415,72$ \\
\hline INSS S/ Serviços Autônomo ${ }^{19}$ & $198.533,40$ & $260.216,33$ \\
\hline Saneamento e Energia & $541.074,79$ & $538.267,99$ \\
\hline Materiais de Consumo & $1.120 .210,85$ & $1.028 .782,42$ \\
\hline Administrativas & $393.079,87$ & $904.720,83$ \\
\hline Aluguéis e Arrendamentos & $163.313,22$ & $176.874,59$ \\
\hline Tributárias & $31.894,45$ & $129.591,54$ \\
\hline Depreciações & $1.579 .425,25$ & $1.456 .880,32$ \\
\hline Manutenção & $1.682 .078,13$ & $673.482,79$ \\
\hline Comunicação & $634.214,87$ & $414.633,54$ \\
\hline Locomoção & $445.496,34$ & $414.081,65$ \\
\hline Provisão para Devedores Duvidosos & $205.524,05$ & 0,00 \\
\hline Outras Despesas Operacionais & $657.276,55$ & $497.909,48$ \\
\hline Transferência de Fundos & $963.562,58$ & $14.818,15$ \\
\hline Reembolsos & $(184.910,73)$ & $(569.418,21)$ \\
\hline Total & $17.474 .934,86$ & $17.023 .013,40$ \\
\hline
\end{tabular}

18 Base de Cálculo = $2001-\mathrm{R} \$ 4.963 .140,22$ e $2000-\mathrm{R} \$ 4.402 .391,62$ extraídos do balancete de verificação - alíquota $26,5 \%$.

19 Base de Cálculo = 2001 - R\$ 992.667,00 e 2000 - R\$ 1.301.081,65 extraídos do balancete de verificação - alíquota $20 \%$. 
Foram incluídos, nesse grupo, o resultado financeiro e despesas com provisões.

e) Outras Receitas e Despesas Operacionais

Foram considerados os valores recebidos a título de aluguéis e arrendamentos.

\title{
f) Resultado Não Operacional
}

Foram consideradas como Receitas Não Operacionais outras receitas não operacionais e as doações e subvenções para custeio foram incluídas nesse grupo.O valor das despesas não operacionais foi retirado da demonstração. Foi incluído, nesse grupo, o resultado com a alienação do ativo imobilizado.

\author{
g) Contribuição Social \\ Incluída a Contribuição Social por tratar-se de contribuição para a \\ seguridade social de acordo com Art. 23 da Lei $n^{\circ} 8.212$.
}

h) Resultado do Certificado

Acrescentamos o item Resultado do Certificado, com o objetivo de demonstrar qual foi o resultado em função da opção de ter o Certificado de Entidade Beneficente de Assistência Social. 
TABELA 38 - Proposta de Demonstração dos Resultados com Certificado UCDB MSMT - UNIVERSIDADE CATÓLICA DOM BOSCO DEMONSTRAÇÃO DOS RESULTADOS COM CERTIFICADO DO PERÍODO DE 01/01 A 31/12

\begin{tabular}{lrr} 
RECEITAS DO CERTIFICADO & 2001 & \multicolumn{1}{c}{2000} \\
INSS & $4.742 .285,98$ & $4.250 .408,49$ \\
COFINS & $1.361 .795,42$ & $1.090 .183,50$ \\
C.SOCIAL & $1.147 .026,67$ & $467.545,27$ \\
TOTAL RECEITAS & $\mathbf{7 . 2 5 1 . 1 0 8 , 0 7}$ & $\mathbf{5 . 8 0 8 . 1 3 7 , 2 5}$ \\
CUSTOS DO CERTIFICADO & & \\
BOLSAS DE ESTUDOS & $3.523 .395,20$ & $3.206 .773,79$ \\
ASSISTENCIA SOCIAL & $3.945 .278,03$ & $1.290 .026,04$ \\
TOTAL CUSTOS & $\mathbf{7 . 4 6 8 . 6 7 3 , 2 3}$ & $\mathbf{4 . 4 9 6 . 7 9 9 , 8 3}$ \\
& & \\
RESULTADO DO EXERCÍCIO & $\mathbf{- 2 1 7 . 5 6 5 , 1 6}$ & $\mathbf{1 . 3 1 1 . 3 3 7 , 4 2}$
\end{tabular}

Foram utilizados na aplicação do modelo, conforme apresentado no item 4.4.2 do capítulo 4, os conceitos de custo de oportunidade para a apuração do resultado com o certificado.

Constata-se através dos resultados, que no ano de 2001, a UCDB aplicou R\$ 217.565,16 (duzentos e dezessete mil, quinhentos e sessenta e cinco reais e dezesseis centavos) a mais do que obteve de benefícios nesse mesmo período, e que, no ano de 2000, aplicou R\$ 1.311.337,42 (hum milhão, trezentos e onze mil, trezentos e trinta e sete reais e quarenta e dois centavos) a menos do que obteve de benefícios em 2000. Observa-se, pois, que, no ano de 2000, a UCDB descumpriu a legislação que estabelece que o valor da aplicação não pode ser inferior ao valor dos benefícios usufruídos, no caso a contribuição para a seguridade social, entretanto, no ano de 2001, a mesma realmente praticou a filantropia, haja vista ter investido mais do que recebeu de benefícios. 


\begin{tabular}{|c|c|c|}
\hline \multicolumn{3}{|l|}{ 5.5.2 PUC/Rio } \\
\hline \multirow{2}{*}{\multicolumn{3}{|c|}{$\begin{array}{l}\text { TABELA } 39 \text { - Proposta de Demonstração dos Resultados PUC/Rio } \\
\text { FACULDADES CATÓLICAS - PUC/RIO }\end{array}$}} \\
\hline & & \\
\hline \multicolumn{3}{|c|}{ DEMONSTRAÇÃO DO RESULTADO DO PERÍODO DE 01/01 A 31/12 } \\
\hline & 2001 & 2000 \\
\hline \multicolumn{3}{|l|}{ RECEITA OPERACIONAL BRUTA } \\
\hline \multicolumn{3}{|l|}{ SERVIÇOS } \\
\hline ESCOLARES & $91.946 .378,00$ & $84.220 .755,00$ \\
\hline OUTROS SERVIÇOS & $11.597 .726,00$ & $10.812 .241,00$ \\
\hline \multicolumn{3}{|l|}{ GRATUIDADES } \\
\hline BOLSAS DE ESTUDO & $21.951 .178,00$ & 21.268.838,00 \\
\hline ASSISTÊNCIA SOCIAL & $11.008 .190,00$ & $13.274 .000,00$ \\
\hline TOTAL RECETAS DE SERV IÇOS & 136.503.472,00 & $\mathbf{1 2 9 . 5 7 5 . 8 3 4 , 0 0}$ \\
\hline \multicolumn{3}{|l|}{ DEDUÇÕES DA RECEITA } \\
\hline COFINS & 4.095.104,16 & $3.887 .275,02$ \\
\hline RECEITA OPERACIONAL LÍQUIDA & $132.408 .367,84$ & 125.688.558,98 \\
\hline CUSTOS DOS SERVIÇOS PRESTADOS & 42.426.099,00 & 38.635.427,00 \\
\hline SALÁRIOS & $31.310 .774,00$ & 28.513.230,00 \\
\hline ENCARGOS SOCIAIS & $11.115 .325,00$ & $10.122 .197,00$ \\
\hline ATIVIDADES DE EXTENSÃO & 0,00 & 0,00 \\
\hline CAPACITAÇÃO DE PESSOAL & 0,00 & 0,00 \\
\hline LUCRO BRUTO & 89.982.268,84 & 87.053.131,98 \\
\hline DESPESAS OPERACIONAIS & 86.292.146,00 & 76.786.022,00 \\
\hline ADMINISTRATIVAS & $84.546 .732,00$ & $73.828 .646,00$ \\
\hline ENCARGOS FINANCEIROS LÍQUIDOS & $(2.535 .924,00)$ & $(1.429 .572,00)$ \\
\hline DESPESAS COM PROVISÕES & $4.281 .338,00$ & $4.386 .948,00$ \\
\hline OUTRAS RECEITAS E DESPESAS OPERACIONAIS & $1.403 .385,00$ & $1.247 .310,00$ \\
\hline PATRIMONIAIS & $1.403 .385,00$ & $1.247 .310,00$ \\
\hline RESULTADO OPERACIONAL & $5.093 .507,84$ & $11.514 .419,98$ \\
\hline RESULTADO NÃO OPERACIONAL & 9.493.946,00 & 6.945.070,00 \\
\hline RECEITAS NÃO OPERACIONAIS & $9.493 .946,00$ & $6.945 .070,00$ \\
\hline DESPESAS NÃO OPERACIONAIS & 0,00 & 0,00 \\
\hline GANHOS/PERDAS C/ ATIVO IMOBILIZADO & 0,00 & 0,00 \\
\hline RESULTADO ANTES DA C. SOCIAL & 14.587.453,84 & $18.459 .489,98$ \\
\hline CONTRIBUIÇÃO SOCIAL & $1.312 .870,85$ & $1.661 .354,10$ \\
\hline RESULTADO ANTES DO CERTIFICADO & 13.274.582,99 & $16.798 .135,88$ \\
\hline RESULTADO COM CERTIFICADO & $(10.246 .022,99)$ & $(12.513 .995,88)$ \\
\hline RECEITAS DO CERTIFICADO & $22.713 .345,01$ & $22.028 .842,12$ \\
\hline CUSTOS DO CERTIFICADO & $32.959 .368,00$ & $34.542 .838,00$ \\
\hline RESULTADO DO EXERCÍCIO & 3.028.560,00 & 4.284.140,00 \\
\hline
\end{tabular}

a) Receita Operacional Bruta

Foram retirados da demonstração de resultado somente os valores a título de 
mensalidades, cursos periódicos, prestações de serviços, taxas internas e outras receitas.

Foram incluídos como receitas de gratuidades os valores com Bolsas de Estudo e Assistência Social contabilizados em Contas de Compensação.

b) Deduções da Receita

Incluída a Cofins por tratar-se de contribuição para a seguridade social de acordo com Art. 23 da Lei $n^{\circ} 8.212$.

c) Custos dos Serviços Prestados

Não é objeto de análise e estudo deste trabalho os custos dos serviços prestados dessas instituições, entretanto, optamos por separar alguns custos sem entrar na discussão particular de cada um. Foram incluídos como custos:

- Salários dos Docentes;

- Encargos Sociais incidentes sobre os salários dos docentes: 26,5\% INSS, $8 \%$ FGTS e 1\% PIS;

d) Despesas Operacionais

Foram sintetizadas as diversas contas apresentadas na demonstração de resultado em despesas administrativas, conforme quadro abaixo:

TABELA 40 - Despesas Administrativas PUC/Rio

\begin{tabular}{|l|l|l|}
\hline CONTA & VALOR 2001 & VALOR 2000
\end{tabular}




\begin{tabular}{|l|r|r|}
\hline Pessoal & 31.621 .016 & 26.142 .051 \\
\hline Encargos Sociais ${ }^{20}$ & 14.037 .168 & 13.591 .510 \\
\hline Serviços Profissionais Terceiros & 16.054 .794 & 14.143 .128 \\
\hline INSS S/ Salários e Serviços Autônomo & 9.008 .015 & 8.924 .207 \\
\hline Materiais & 4.248 .264 & 3.364 .297 \\
\hline Despesas Gerais & 6.378 .293 & 5.562 .094 \\
\hline Impostos e Taxas & 15.968 & 21.844 \\
\hline Depreciações & 5.321 .433 & 4.867 .061 \\
\hline Provisão para Devedores Duvidosos & $(46.565)$ & $(39.537)$ \\
\hline Outras Despesas Operacionais & 600.661 & 536.544 \\
\hline Ressarcimentos de Projetos Específicos & $(2.692 .315)$ & $(3.284 .553)$ \\
\hline Total & 84.546 .732 & 73.828 .646 \\
\hline
\end{tabular}

Foram incluídos, nesse grupo, o resultado financeiro e despesas com provisões.

e) Outras Receitas e Despesas Operacionais

Foram considerados os valores recebidos a título de receitas patrimoniais.

f) Resultado Não Operacional

Foram consideradas como Receitas Não Operacionais as doações e subvenções para custeio.

g) Contribuição Social

${ }^{20}$ Foram excluídos os valores já atribuídos como custos: 2001 - R\$ 2.817.970 e 2000 - R\$ 2.566.191 
Incluída a Contribuição Social por tratar-se de contribuição para a seguridade social de acordo com Art. 23 da Lei $n^{\circ} 8.212$.

h) Resultado do Certificado

Acrescentamos o item Resultado do Certificado, com o objetivo de demonstrar qual foi o resultado apurado, em função da opção de ter o Certificado de Entidade de Fins Filantrópicos.

TABELA 41 - Proposta de Demonstração dos Resultados com Certificado PUC/Rio

FACULDADES CATÓLICAS - PUC/RIO DEMONSTRAÇÃO DO RESULTADO COM CERTIFICADO DO PERÍODO DE 01/01 A 31/12

RECEITAS DO CERTIFICADO

INSS

COFINS

C.SOCIAL

TOTAL RECEITAS

CUSTOS DO CERTIFICADO

BOLSAS DE ESTUDO

ASSISTÊNCIA SOCIAL

TOTAL CUSTOS

RESULTADO DO EXERCÍCIO
2001

2000

$\begin{array}{rr}17.305 .370,00 & 16.480 .213,00 \\ 4.095 .104,16 & 3.887 .275,02 \\ 1.312 .870,85 & 1.661 .354,10 \\ \mathbf{2 2 . 7 1 3 . 3 4 5 , 0 1} & \mathbf{2 2 . 0 2 8 . 8 4 2 , 1 2}\end{array}$

$\begin{array}{ll}21.951 .178,00 & 21.268 .838,00 \\ 11.008 .190,00 & 13.274 .000,00 \\ \mathbf{3 2 . 9 5 9 . 3 6 8 , 0 0} & \mathbf{3 4 . 5 4 2 . 8 3 8 , 0 0} \\ & \\ \mathbf{- 1 0 . 2 4 6 . 0 2 2 , 9 9} & \mathbf{- 1 2 . 5 1 3 . 9 9 5 , 8 8}\end{array}$

Assim como na aplicação do modelo a UCDB, foram utilizados os mesmos conceitos para apuração do resultado com o certificado para a PUC/Rio.

Os resultados demonstram, que nos anos de 2000 e 2001, a PUC/Rio efetuou filantropia, haja vista a instituição ter aplicado $\mathrm{R} \$$ 12.513.995,88 (onze 
milhões, quinhentos e treze mil, novecentos e noventa e cinco reais e oitenta e oito centavos) e R $\$ 10.246 .022,99$ (dez milhões, duzentos e quarenta e seis mil, vinte e dois reais e noventa e nove centavos) nos anos de 2000 e 2001 respectivamente, a mais do que recebeu de benefícios, ou seja isenção da seguridade social, no mesmo período.

\subsection{Sugestão para Aperfeiçoamento da NBC T 10.19}

O Conselho Federal de Contabilidade aprovou através da Resolução n ${ }^{\circ} 877$ de 18 de abril de 2000, a NBC T 10.19 (Anexo B), que trata das normas de Contabilidade aplicáveis às entidades sem finalidade de lucros. O item 10.19.1.2. da citada NBC T prescreve:

"Destina-se, também, a orientar o atendimento às exigências legais sobre procedimentos contábeis a serem cumpridos pelas pessoas jurídicas de direito privado sem finalidade de lucros, especialmente entidades beneficentes de assistência social (Lei Orgânica da Seguridade Social), para emissão do Certificado de Entidade de Fins Filantrópicos, da competência do Conselho Nacional de Assistência Social (CNAS)’”.

Verifica-se que a norma citada, aplica-se às entidades objeto de estudo, não estando as mesmas vinculadas a qualquer outra norma contábil.

O item 10.19.3 trata das demonstrações contábeis exigidas para estas instituições, bem como a forma de apresentação. Os mesmos estabelecem:

“10.19.3.1 - As demonstrações contábeis que devem ser elaboradas pelas 
entidades sem finalidade de lucros são as determinadas pela NBC T 3 - Conceito, Conteúdo, Estrutura e Nomenclatura das Demonstrações Contábeis, e a sua divulgação pela NBC T 6 - Da Divulgação das Demonstrações Contábeis.

\subsection{2 - Conteúdo e Estrutura}

3.3.2.1 - A demonstração do resultado compreenderá:

a) as receitas e os ganhos do período, independentemente de seu recebimento;

b) os custos, despesas, encargos e perdas pagos ou incorridos, correspondentes a esses ganhos e receitas.

3.3.2.2 - A compensação de receitas, custos e despesas é vedada.

3.3.2.3 - A demonstração do resultado evidenciará, no mínimo, e de forma ordenada:

a) as receitas decorrentes da exploração das atividades-fins;

b) os impostos incidentes sobre as operações, os abatimentos, as devoluções e os cancelamentos;

c) os custos dos produtos ou mercadorias vendidos e dos serviços prestados;

d) o resultado bruto do período;

e) os ganhos e perdas operacionais;

f) as despesas administrativas, com vendas, financeiras e outras e as receitas financeiras; 
g) o resultado operacional;

h) as receitas e despesas e os ganhos e perdas não decorrentes das atividades-fins;

i) o resultado antes das participações e dos impostos;

j) as provisões para impostos e contribuições sobre o resultado;

1) as participações no resultado;

m) o resultado líquido do período".

Constatou-se, quando da análise das demonstrações contábeis da UCDB e PUC/Rio, que as instituições não observam as orientações estabelecidas na referida norma. As demonstrações de resultados apresentadas, contrariam a letra $b$ do item 3.3.2.1, que estabelece: "os custos, despesas, encargos e perdas pagos ou incorridos, correspondentes a esses ganhos e receitas". Quando não contabilizam as receitas com beneficências ou gratuidades em contas de resultado, os custos incorridos em função dessas serão comparados com as receitas não correspondentes a eles, distorcendo, dessa forma, o resultado.

Em consulta realizada ao Conselho Federal de Contabilidade (Apêndice D), verifica-se pela resposta, aprovada pelo plenário do referido conselho (Apêndice E), que o Conselho recomenda o registro das beneficências e os benefícios obtidos em função do certificado, em contas de compensação. Essa orientação, contraria o regime de competência (Anexo A), e também a NBC T 10.19 (Anexo B) todos editados pelo Conselho Federal de Contabilidade.

Nesse aspecto, não se trata de sugestão à norma e sim o cumprimento da 
mesma, visto que nem mesmo as auditorias independentes têm feito qualquer recomendação a esse respeito.

Nossa sugestão, pauta-se na alteração das letras c e k do item 10.19.3.3. que tratam especificamente das notas explicativas.

“10.19.3.3 - As demonstrações contábeis devem ser complementadas por notas explicativas que contenham, pelo menos, as seguintes informações:

(..)

c) as contribuições previdenciárias relacionadas com a atividade assistencial devem ser demonstradas como se a entidade não gozasse de isenção, conforme normas do Instituto Nacional do Seguro Social (INSS);

(...)

k) as entidades beneficiadas com isenção de tributos e contribuições devem evidenciar suas receitas com e sem gratuidade de forma segregada, e os benefícios fiscais gozados”.

Com base na norma apresentada, entendemos que as situações prescritas nos itens acima, podem até ser evidenciadas em notas explicativas, entretanto, deveriam estar incluídas também no item "Conteúdo e Estrutura das Demonstrações de Resultado" estabelecidos na NBC T 3. Sugerimos, também, a alteração dos textos, conforme abaixo:

“c) as contribuições para a seguridade social relacionada com a atividade assistencial devem ser demonstradas como se a entidade não gozasse de 
isenção, conforme normas do Instituto Nacional do Seguro Social (INSS)". “k) as entidades beneficiadas com isenção de tributos e contribuições devem contabilizar suas receitas com e sem gratuidade de forma segregada, e os benefícios físcais gozados". 


\section{CONCLUSÕES}

Procuramos, ao longo deste trabalho, abordar o tema proposto de forma ampla e profunda, de modo a dar sustentação à solução proposta.

No que tange à questão problema, constatou-se que a Contabilidade pode apurar e evidenciar os resultados com o certificado de maneira a subsidiar a gestão das IESCEBAS, o governo e sociedade na tomada de decisão. A Contabilidade, como ciência, possibilita à sociedade, através dos seus instrumentos, conhecer a forma, como e onde os recursos estão sendo aplicados, desde que realizada de modo correto.

Acreditamos ter comprovado a hipótese levantada, posto que se pode confirmar que o certificado gera resultados e que podem ser apurados e evidenciados pela Contabilidade das IESCEBAS.

No que se refere ao objetivo geral estabelecido no capítulo inicial, conclui-

se

que foi plenamente atingido, haja vista que a proposta apresentada para a Demonstração de Resultado e também do Resultado do Certificado contribui significativamente para a melhoria das informações contábeis das IESCEBAS.

Ressalte-se, pois, o que estabelece o Accouting Research Study $\mathrm{n}^{\circ} 1$, editado 
pelo AICPA, em 1961 apud IUDÍCIBUS (2000:116): “Os demonstrativos contábeis deveriam evidenciar o que for necessário, a fim de não torná-los enganosos”. Constata-se, portanto, que esta opinião procura evidenciar que as demonstrações contábeis devem prestar informações corretas aos seus usuários, sejam eles quais forem.

As informações apresentadas nas demonstrações propostas são de extrema importância para os usuários, não os tornando, dessa forma, enganosos para os que dele se utilizam.

Quanto aos objetivos específicos, verifica-se que primeiro com relação à identificação das características das IESCEBAS, as mesmas foram levantadas e apresentadas no capítulo 2 deste trabalho.

O segundo e terceiro objetivos tratavam de verificar os conhecimentos e a legislação por parte das IESCEBAS, bem como analisar os procedimentos contábeis adotados por essas instituições.

O quarto objetivo específico trata da apresentação de modelo de demonstração de resultado e do certificado. Esse objetivo, também, foi atingido, haja vista a apresentação das propostas no capítulo 4 deste trabalho.

O modelo de demonstração de resultado reconhece as receitas e despesas de acordo com os princípios fundamentais de Contabilidade, principalmente no que diz respeito ao princípio da competência. O modelo permite que a instituição verifique como seria o resultado sem o certificado, e quais os impactos do mesmo no patrimônio da entidade.

O resultado do certificado, da forma como foi apresentado, permite à 
sociedade e ao governo conhecer o quanto está se gastando com o que se deixou de recolher, se está ou não fazendo filantropia, e torna-se, também, um importante instrumento de marketing para as instituições, quando, é claro, investem mais do que estão obrigadas. Permite, igualmente, que os gestores conheçam através da Contabilidade qual é a real situação da instituição em determinado momento. $\mathrm{O}$ modelo permite conhecer o valor que a instituição tem que aplicar em beneficências, o quanto já aplicou e se está cumprindo o que está estabelecido em lei.

Ressalte-se, pois, a importância para a sociedade conhecer, de forma clara e transparente, o como, quando e onde estão sendo aplicados os recursos que deveriam ser repassados ao governo e que, no entanto, são confiados a essas entidades.

O quinto objetivo visava à aplicação do modelo proposto em IESCEBAS, procurando realizar análises dos resultados obtidos.

Por fim, o sexto objetivo proposto trata da apresentação de sugestões à NBC T 10.19, o que foi feito no item 5.7 do capítulo 5.

Diante de tudo o que foi apresentado, as principais conclusões do presente trabalho foram:

a) não existe clareza por parte das instituições de quais são suas obrigações, bem como quais são os benefícios gerados em função do certificado;

b) a maioria das instituições gasta mais do que recebem, entretanto, algumas instituições informaram que não cumpriram o percentual estabelecido em lei, ou seja, gastaram menos do que receberam;

c) existem divergências quanto aos procedimentos contábeis adotados e 
que não existe uniformidade na apuração e evidenciação dos resultados obtidos com o certificado.

d)as instituições não contabilizam as beneficências em contas de resultados, entretanto, os custos e despesas ocorridos em função das mesmas são contabilizados no resultado, contrariando, dessa forma, o princípio de competência;

e) não são observadas quando da elaboração das demonstrações contábeis, as orientações da NBC T 10.19 e do Parágrafo Único do Art. $4^{\circ}$ do Decreto 2536;

f) o resultado produz resultados e portanto podem ser contabilizados;

g) os modelos propostos apuram e evidenciam o resultado da instituição incluindo os efeitos do certificado, e também permitem o acompanhamento por parte da instituição de como está sua situação quanto às exigências legais.

As principais contribuições geradas pela presente pesquisa à ciência contábil, governo, IESCEBAS e sociedade, concentram-se nos seguintes aspectos:

a) definição do que é uma IESCEBAS;

b) apresentação de modelo para demonstração do resultado das IESCEBAS;

c) apresentação de modelo para apuração e evidenciação do resultado com o certificado das IESCEBAS;

d) proposição de lançamentos contábeis; e 
e) sugestão para aperfeiçoamento da NBC T 10.19 .

Através do presente estudo, pode-se constatar a necessidade de ampliação da pesquisa, principalmente no que diz respeito aos aspectos intangíveis gerados pelo certificado e também que possa ser verificada qual a contribuição que essas instituições trazem para a sociedade e se é vantagem ou não para o governo confiar a essas instituições a administração desses recursos ou se haveria alguma outra alternativa.

Cabe-nos, portanto, o papel de realizar estudos e pesquisas que possam validar ou não os instrumentos utilizados na dinâmica das organizações com o propósito de contribuirmos para uma maior valorização da Contabilidade no contexto social. 
ANEXOS 
Anexo A - RESOLUÇÃO 750/93 - CFC

\section{$\underline{\text { RESOLUÇÃO CFC N. }{ }^{\circ} 750 / 93}$}

Dispõe sobre os Princípios Fundamentais de Contabilidade.

O CONSELHO FEDERAL DE CONTABILIDADE, no exercício de suas atribuições legais e regimentais,

CONSIDERANDO que a evolução da última década na área da Ciência Contábil reclama a atualização substantiva e adjetiva dos Princípios Fundamentais de Contabilidade a que se refere a Resolução CFC 530/81.

\section{RESOLVE:}

\section{CAPÍTULO I}

\section{DOS PRINCÍPIOS E DE SUA OBSERVÂNCIA}

Art. $1^{\circ}$ - Constituem PRINCÍPIOS FUNDAMENTAIS DE CONTABILIDADE (P.F.C.) os enunciados por esta Resolução.

$\S 1^{\circ}$ - A observância dos Princípios Fundamentais de Contabilidade é obrigatória no exercício da profissão e constitui condição de legitimidade das Normas Brasileiras de Contabilidade (NBC).

$\S 2^{\circ}$ - Na aplicação dos Princípios Fundamentais de Contabilidade há situações concretas, a essência das transações deve prevalecer sobre seus aspectos formais. 


\section{CAPÍTULO II}

\section{DA CONCEITUAÇÃO, DA AMPLITUDE E DA ENUMERAÇÃO}

Art. $2^{\circ}$ - Os Princípios Fundamentais de Contabilidade representam a essência das doutrinas e teorias relativas à Ciência da Contabilidade, consoante o entendimento predominante nos universos científico e profissional de nosso País. Concernem, pois, à Contabilidade no seu sentido mais amplo de ciência social, cujo objeto é o Patrimônio das Entidades.

Art. $3^{\circ}$ - São Princípios Fundamentais de Contabilidade:

I) o da ENTIDADE;

II) o da CONTINUIDADE;

III) o da OPORTUNIDADE;

IV) o do REGISTRO PELO VALOR ORIGINAL;

V) o da ATUALIZAÇÃO MONETÁRIA;

VI) o da COMPETÊNCIA e

VII) o da PRUDÊNCIA.

\section{SEÇÃO I}

\section{O PRINCÍPIO DA ENTIDADE}

Art. $4^{\circ}$ - O Princípio da ENTIDADE reconhece o Patrimônio como objeto da Contabilidade e afirma a autonomia patrimonial, a necessidade da diferenciação de um Patrimônio particular no universo dos patrimônios existentes, independentemente de pertencer a uma pessoa, um conjunto de pessoas, uma sociedade ou instituição de qualquer natureza ou finalidade, com ou sem fins lucrativos. Por conseqüência, nesta acepção, o Patrimônio não se confunde com aqueles dos seus sócios ou proprietários, no caso de sociedade ou instituição.

$\S$ único - O PATRIMÔNIO pertence à ENTIDADE, mas a recíproca não é 
verdadeira. A soma ou agregação contábil de patrimônios autônomos não resulta em nova ENTIDADE, mas numa unidade de natureza econômico-contábil.

\section{SEÇÃO II}

\section{O PRINCÍPIO DA CONTINUIDADE}

Art. $5^{\circ}$ - A CONTINUIDADE ou não da ENTIDADE, bem como sua vida definida ou provável, devem ser consideradas quando da classificação e avaliação das mutações patrimoniais, quantitativas e qualitativas.

$\S 1^{\circ}$ - A CONTINUIDADE influencia o valor econômico dos ativos e, em muitos casos, o valor ou o vencimento dos passivos, especialmente quando a extinção da ENTIDADE tem prazo determinado, previsto ou previsível.

$\S 2^{\circ}$ - A observância do Princípio da CONTINUIDADE é indispensável à correta aplicação do Princípio da COMPETÊNCIA, por efeito de se relacionar diretamente à quantificação dos componentes patrimoniais e à formação do resultado, e de constituir dado importante para aferir a capacidade futura de geração de resultado.

\section{SEÇÃO III}

\section{O PRINCÍPIO DA OPORTUNIDADE}

Art. $6^{0}$ - O Princípio da OPORTUNIDADE refere-se, simultaneamente, à tempestividade e à integridade do registro do patrimônio e das suas mutações, determinando que este seja feito de imediato e com a extensão correta, independentemente das causas que as originaram.

\section{OPORTUNIDADE:}

$\S$ único - Como resultado da observância do Princípio da

I - desde que tecnicamente estimável, o registro das variações patrimoniais deve ser feito mesmo na hipótese de somente existir razoável certeza de sua ocorrência; 
II - o registro compreende os elementos quantitativos e qualitativos, contemplando os aspectos físicos e monetários;

III - o registro deve ensejar o reconhecimento universal das variações ocorridas no patrimônio da ENTIDADE, em um período de tempo determinado, base necessária para gerar informações úteis ao processo decisório da gestão.

\section{SEÇÃO IV}

\section{ORIGINAL}

\section{O PRINCÍPIO DO REGISTRO PELO VALOR}

Art. $7^{0}$ - Os componentes do patrimônio devem ser registrados pelos valores originais das transações com o mundo exterior, expressos a valor presente na moeda do País, que serão mantidos na avaliação das variações patrimoniais posteriores, inclusive quando configurarem agregações ou decomposições no interior da ENTIDADE.

$\S$ único - Do Princípio do REGISTRO PELO VALOR ORIGINAL resulta:

I - a avaliação dos componentes patrimoniais deve ser feita com base nos valores de entrada, considerando-se como tais os resultantes do consenso com os agentes externos ou da imposição destes;

II - uma vez integrado no patrimônio, o bem, direito ou obrigação não poderão ter alterados seus valores intrínsecos, admitindo-se, tãosomente, sua decomposição em elementos e/ou sua agregação, parcial ou integral, a outros elementos patrimoniais;

III - o valor original será mantido enquanto o componente permanecer como parte do patrimônio, inclusive quando da saída deste;

IV - Os Princípios da ATUALIZAÇÃO MONETÁRIA e do REGISTRO PELO VALOR ORIGINAL são compatíveis entre si e complementares, dado que o primeiro apenas atualiza e mantém atualizado o valor de entrada;

V - o uso da moeda do País na tradução do valor dos componentes patrimoniais constitui imperativo de homogeneização quantitativa dos mesmos.

\section{O PRINCÍPIO DA ATUALIZACÃO MONETÁRIA}


Art. $8^{\circ}$ - Os efeitos da alteração do poder aquisitivo da moeda nacional devem ser reconhecidos nos registros contábeis através do ajustamento da expressão formal dos valores dos componentes patrimoniais.

$\S$ único - São resultantes da adoção do Princípio da ATUALIZAÇÃO MONETÁRIA:

I - a moeda, embora aceita universalmente como medida de valor, não representa unidade constante em termos do poder aquisitivo;

II - para que a avaliação do patrimônio possa manter os valores das transações originais (art. $7^{\circ}$ ), é necessário atualizar sua expressão formal em moeda nacional, a fim de que permaneçam substantivamente corretos os valores dos componentes patrimoniais e, por conseqüência, o do patrimônio líquido;

III - a atualização monetária não representa nova avaliação, mas, tão-somente, o ajustamento dos valores originais para determinada data, mediante a aplicação de indexadores, ou outros elementos aptos a traduzir a variação do poder aquisitivo da moeda nacional em um dado período.

\section{SEÇÃO VI}

\section{O PRINCÍPIO DA COMPETÊNCIA}

Art. $9^{\circ}$ - As receitas e as despesas devem ser incluídas na apuração do resultado do período em que ocorrerem, sempre simultaneamente quando se correlacionarem, independentemente de recebimento ou pagamento.

$\S 1^{\circ}$ - O Princípio da COMPETÊNCIA determina quando as alterações no ativo ou no passivo resultam em aumento ou diminuição no patrimônio líquido, estabelecendo diretrizes para classificação das mutações patrimoniais, resultantes da observância do Princípio da OPORTUNIDADE.

$\S 2^{\circ}$ - O reconhecimento simultâneo das receitas e despesas, quando correlatas, é conseqüência natural do respeito ao período em que ocorrer sua geração.

\section{$\S 3^{\circ}$ - As receitas consideram-se realizadas:}

I - nas transações com terceiros, quando estes efetuarem o pagamento ou assumirem compromisso firme de efetivá-lo, quer pela investidura na propriedade de bens anteriormente pertencentes à ENTIDADE, quer pela fruição de serviços por esta prestados; 
II - quando da extinção, parcial ou total, de um passivo, qualquer que seja o motivo, sem o desaparecimento concomitante de um ativo de valor igual ou maior; da intervenção de terceiros;

III - pela geração natural de novos ativos independentemente

IV - no recebimento efetivo de doações e subvenções.

$\S 4^{\circ}$ - Consideram-se incorridas as despesas:

I - quando deixar de existir o correspondente valor ativo, por transferência de sua propriedade para terceiro;

ativo;

II - pela diminuição ou extinção do valor econômico de um

III - pelo surgimento de um passivo, sem o correspondente

\section{SEÇÃO VII}

\section{O PRINCÍPIO DA PRUDÊNCIA}

Art. 10 - O Princípio da PRUDÊNCIA determina a adoção do menor valor para os componentes do ATIVO e do maior para os do PASSIVO, sempre que se apresentem alternativas igualmente válidas para a quantificação das mutações patrimoniais que alterem o patrimônio líquido.

$\S 1^{\mathrm{o}}$ - O Princípio da PRUDÊNCIA impõe a escolha da hipótese de que resulte menor patrimônio líquido, quando se apresentarem opções igualmente aceitáveis diante dos demais Princípios Fundamentais de Contabilidade.

$\S 2^{\circ}$ - Observado o disposto no art. $7^{\circ}$, o Princípio da PRUDÊNCIA somente se aplica às mutações posteriores, constituindo-se ordenamento indispensável à correta aplicação do Princípio da COMPETÊNCIA.

$\S 3^{\circ}$ - A aplicação do Princípio da PRUDÊNCIA ganha ênfase quando, para definição dos valores relativos às variações patrimoniais, devem ser feitas estimativas que envolvem incertezas de grau variável. 
Art. 11 - A inobservância dos Princípios Fundamentais de Contabilidade constitui infração nas alíneas "c", "d" e "e" do art. 27 do Decreto-Lei n. ${ }^{\circ}$ 9.295, de 27 de maio de 1946 e, quando aplicável, ao Código de Ética Profissional do Contabilista.

Art. 12 - Revogada a Resolução CFC n. ${ }^{\circ}$ 530/81, esta Resolução entra em vigor a partir de $1^{\circ}$ de janeiro de 1994.

Brasília, 29 de dezembro de 1993.

\section{Contador IVAN CARLOS GATTI}

Presidente 
Anexo B - NBC T 10.19 DO CFC

\title{
NORMAS BRASILEIRAS DE CONTABILIDADE
}

\author{
NBC T -10 - ASPECTOS CONTÁBEIS ESPECÍFICOS EM ENTIDADES \\ DIVERSAS
}

NBC T - 10.19 - ENTIDADES SEM FINALIDADE DE LUCROS

\subsection{1 - DAS DISPOSIÇÕES GERAIS}

10.19.1.1 - Esta norma estabelece critérios e procedimentos específicos de avaliação, de registros dos componentes e variações patrimoniais e de estruturação das demonstrações contábeis, e as informações mínimas a serem divulgadas em nota explicativa das entidades sem finalidades de lucros.

10.19.1.2 - Destina-se, também, a orientar o atendimento às exigências legais sobre procedimentos contábeis a serem cumpridos pelas pessoas jurídicas de direito privado sem finalidade de lucros, especialmente entidades beneficentes de assistência social (Lei Orgânica da Seguridade Social), para emissão do Certificado de Entidade de Fins Filantrópicos, da competência do Conselho Nacional de Assistência Social (CNAS).

10.19.1.3 - As entidades sem finalidade de lucro são aquelas em que o resultado positivo não é destinado aos detentores do patrimônio líquido e o lucro ou prejuízo são denominados, respectivamente, de superávit ou déficit.

10.19.1.4 - As entidades sem finalidade de lucros exercem atividades assistenciais, de saúde, educacionais, técnico-científicas, esportivas, religiosas, políticas, culturais, beneficentes, sociais, de conselhos de classe e outras, administrando pessoas, coisas, e interesses coexistentes e coordenados em torno de um patrimônio com finalidade comum ou comunitária. 
10.19.1.5 - Essas entidades são constituídas sob a forma de fundações públicas ou privadas, ou sociedades civis, nas categorias de entidades sindicais, culturais, associações de classe, partidos políticos, ordem dos advogados, conselhos federais, regionais e seccionais de profissões liberais, clubes esportivos não-comerciais e outras entidades enquadradas no conceito do item 10.19.1.4.

10.19.1.6 - Aplicam-se às entidades sem finalidade de lucros os Princípios Fundamentais de Contabilidade, bem como as Normas Brasileiras de Contabilidade e suas Interpretações Técnicas e Comunicados Técnicos, editados pelo Conselho Federal de Contabilidade.

10.19.1.7 - Por se tratar de entidades sujeitas aos mesmos procedimentos contábeis, devem ser aplicadas, no que couber, as diretrizes da NBC T 10.4 Fundações e NBC T 10.18 - Entidades Sindicais e Associações de Classe.

\subsection{2 - DO REGISTRO CONTÁBIL}

10.19.2.1 - As receitas e despesas devem ser reconhecidas, mensalmente, respeitando os Princípios Fundamentais de Contabilidade, em especial os Princípios da Oportunidade e da Competência.

10.19.2.2 - As entidades sem finalidade de lucros devem constituir provisão em montante suficiente para cobrir as perdas esperadas, com base em estimativas de seus prováveis valores de realização, e baixar os valores prescritos, incobráveis e anistiados.

10.19.2.3 - As doações, subvenções e contribuições para custeio são contabilizadas em contas de receita. As doações, subvenções e contribuições patrimoniais, inclusive as arrecadadas na constituição da entidade, são contabilizadas no patrimônio social.

10.19.2.4 - As receitas de doações, subvenções e contribuições para custeio ou investimento devem ser registradas mediante documento hábil.

10.19.2.5 - Os registros contábeis devem evidenciar as contas de receitas e despesas, 
superávit ou déficit, de forma segregada, quando identificáveis por tipo de atividade, tais como educação, saúde, assistência social, técnicocientífica e outras, bem como, comercial, industrial ou de prestação de serviços.

10.19.2.6 - As receitas de doações, subvenções e contribuições recebidas para aplicação específica, mediante constituição ou não de fundos, devem ser registradas em contas próprias segregadas das demais contas da entidade.

10.19.2.7 - O valor do superávit ou déficit do exercício deve ser registrado na conta Superávit ou Déficit do Exercício enquanto não aprovado pela assembléia dos associados e após a sua aprovação, deve ser transferido para a conta Patrimônio Social.

\subsection{3 - DAS DEMONSTRAÇÕES CONTÁBEIS}

10.19.3.1 - As demonstrações contábeis que devem ser elaboradas pelas entidades sem finalidade de lucros são as determinadas pela NBC T 3 - Conceito, Conteúdo, Estrutura e Nomenclatura das Demonstrações Contábeis, e a sua divulgação pela NBC T 6 - Da Divulgação das Demonstrações Contábeis.

10.19.3.2 - Na aplicação das normas contábeis, em especial a NBC T 3, a conta Capital deve ser substituída por Patrimônio Social, integrante do grupo Patrimônio Líquido, e a conta Lucros ou Prejuízos Acumulados por Superávit ou Déficit do Exercício.

10.19.3.3 - As demonstrações contábeis devem ser complementadas por notas explicativas que contenham, pelo menos, as seguintes informações:

a) o resumo das principais práticas contábeis;

b) os critérios de apuração das receitas e das despesas, especialmente com gratuidades, doações, subvenções, contribuições e aplicações de recursos; 
C) as contribuições previdenciárias relacionadas com a atividade assistencial devem ser demonstradas como se a entidade não gozasse de isenção, conforme normas do Instituto Nacional do Seguro Social (INSS);

d) as subvenções recebidas pela entidade, a aplicação dos recursos e as responsabilidades decorrentes dessas subvenções;

e) os fundos de aplicação restrita e responsabilidades decorrentes desses fundos;

f) evidenciação dos recursos sujeitos a restrições ou vinculações por parte do doador;

g) eventos subseqüentes à data do encerramento do exercício que tenham, ou possam vir a ter efeito relevante sobre a situação financeira e os resultados futuros da entidade;

h) as taxas de juros, as datas de vencimento e as garantias das obrigações a longo prazo;

i) informações sobre os tipos de seguro contratados;

j) as entidades educacionais, além das notas explicativas, devem evidenciar a adequação das receitas com as despesas de pessoal, segundo parâmetros estabelecidos pela Lei das Diretrizes e Bases da Educação e sua regulamentação;

k) as entidades beneficiadas com isenção de tributos e contribuições devem evidenciar suas receitas com e sem gratuidade de forma segregada, e os benefícios fiscais gozados. (NBCT1019.doc) 


\section{REFERÊNCIAS BIBLIOGRÁFICAS}

ARAÚJO, Osório Cavalcante. A utilização de informações contábeis para o processo de gestão de organizações do terceiro setor situadas no estado do Ceará. 2002. 162 p. Dissertação de Mestrado em Controladoria e Contabilidade - Faculdade de Economia, Administração e Contabilidade da Universidade de São Paulo. São Paulo.

BENEDICTO, Gideon Carvalho de. Contribuição ao estudo de um sistema de contabilidade gerencial para uma gestão eficaz das instituições de ensino. 1997. 230 p. Tese de Doutorado em Controladoria e Contabilidade - Faculdade de Economia, Administração e Contabilidade da Universidade de São Paulo. São Paulo.

BEUREN, Ilse Maria. Conceituação e contabilização do custo de oportunidade. Caderno de Estudos FIPECAFI. São Paulo, nº 08, p. 1-12, abril de 1993.

BILAS, Richard A. Teoria macroeconômica: uma análise gráfica. Rio de Janeiro: Forense-Universitária, 1976.

BRASIL, Decreto n ${ }^{\circ} 2.536$, de 6 de abril de 1998. Dispõe sobre a concessão do Certificado de Entidade de Fins Filantrópicos a que se refere o inciso IV do art. 18 da Lei 8742, de 7 de Dezembro de 1993, e dá outras providências.

BRASIL, Decreto $\mathrm{n}^{\circ} 4.499$, de 4 de dezembro de 2002. Altera o Art. $3^{\circ}$ do Decreto $\mathrm{n}^{\mathrm{o}}$ 2.536, de 6 de Abril de 1998.

BRASIL, Lei n ${ }^{0} 10.260$, de 12 de julho de 2001. Dispõe sobre o Fundo de Financiamento ao estudante do Ensino Superior e dá outras providências.

BRASIL, Lei no 8.212, de 24 de julho de 1991. Dispõe sobre a organização da Seguridade Social, institui Plano de Custeio e dá outras providências. http://wwwt.senado.gov.br/servlets/NJUR.Filtro?tipo=LEI\&secao=NJUILEGBRAS \&numLe... Acesso em: 24.jan.2002.

BRASIL, Lei $\mathrm{n}^{\circ}$ 6.404, de 15 de dezembro de 1976. Dispõe sobre as sociedades por ações.

BRASIL, Lei no 9.394, de 20 de dezembro de 1996. Estabelece as diretrizes e bases da educação nacional.

BRASIL. Código Comercial. Organizador: Juarez de Oliveira. 40 ed. São Paulo: Saraiva, 1995.

BRASIL. Constituição de 1988: Constituição Federal. Organizador: Pedro de Milanélo Piovezane; Coordenadora: Dulce Eugênia de Oliveira. 4 ed. São Paulo: Rideel, 1999.

CATELLI, Armando. Controladoria - uma abordagem da gestão econômica 
GECON. 2 ed. São Paulo: Atlas, 2001.

CERVO, Amado Luiz, BERVIAN, Pedro Alcino. Metodologia científica. 4 ed. São Paulo: Makron Books, 1996.

CHIESA, Clélio. A competência do estado brasileiro para desonerar da tributação e regulamentar as imunidades condicionadas. 2000. 402 p. Tese de Doutorado em Direito Tributário - Pontifícia Universidade Católica de São Paulo. São Paulo.

COUTINHO, C. N. Fontes do pensamento político de Gramsci. Porto Alegre: L \& PM, 1981.

DRUCKER, Peter F. Administração de organizações sem fins lucrativos: princípios e práticas.São Paulo: Pioneira, 1997.

EQUIPE DE PROFESSORES FEA/USP. Contabilidade introdutória. 9 ed. São Paulo: Atlas, 1998.

FALCÃO, Ricardo. Entrevista disponível em $<\underline{\text { htp: } / / \text { www.dearo.com/html/paginas/entrevista com ricardo falcao.asp }}>$ acesso em 22.05 .2002

FERNANDES, Rubens César. O que é Terceiro Setor?. São Paulo: 1996. Disponível $\mathrm{em}<\mathrm{http} /$ /www.rits.org.br/idac_em3.html $>$ acesso em 17.10.2002.

FREITAS, Paulo Roberto C. F. de. O foco na gestão. Revista Ensino Superior. São Paulo, ano IV, n 45, p. 40-42, junho de 2002.

GIBSON, James L., IVANCEVICH, John M. e DONNELLY, James H. Organizações: comportamento, estrutura e processo. São Paulo: Atlas, 1988.

HENDRIKSEN, Eldon S. e BREDA, Michael F. Van. Teoria da Contabilidade. São Paulo: Atlas, 1999.

HORNGREN, Charles T., FOSTER, George e DATAR, Srikant M. Contabilidade de Custos. Rio de Janeiro: LTC, 2000.

HUDSON, Mike. Administrando organizações do terceiro setor. São Paulo: Makron Books, 1999.

IOSCHPE, Evelyn Berg. et. al. $3^{\circ}$ Setor: desenvolvimento social sustentado. Rio de Janeiro: Paz e Terra, 1997.

IUDÍCIBUS, Sérgio de. Teoria da contabilidade. São Paulo: Atlas, 2000. . Contabilidade gerencial. São Paulo: Atlas, 1992.

IUDÍCIBUS, Sérgio de, MARTINS, Eliseu e GELBCKE, Ernesto Rubens. Manual de contabilidade das sociedades por ações (aplicável às demais sociedades). São Paulo: Atlas, 2000.

KOTLER, Philip e FOX, Karen F.A. Marketing estratégico para instituições educacionais. São Paulo: Atlas, 1994. 
MARTINS, Eliseu. Contabilidade de custos. São Paulo: Atlas, 2000.

Contabilidade de entidades de fins não lucrativos. Boletim IOB Temática Contábil. São Paulo, ano XXXIV, nº 33, p.1-5, agosto 2000.

(Organizador) Avaliação de empresas: da mensuração contábil a econômica. São Paulo: Atlas, 2001.

MARTINS, Gilberto de Andrade e LINTZ, Alexandre. Guia para elaboração de monografias e trabalhos de conclusão de curso. São Paulo: Atlas, 2000.

MAURO, Carlos Alberto. Preço de transferência baseado no custo de oportunidade: Um instrumento para promoção da eficácia empresarial. 1991. 204 p. Dissertação de Mestrado em Controladoria e Contabilidade - Faculdade de Economia, Administração e Contabilidade da Universidade de São Paulo. São Paulo.

MENDES, Glauson. Estratégia para a excelência administrativa. Revista Ensino Superior. São Paulo, ano IV, n 47, p. 42-43, agosto de 2002.

MILLER, Roger Leroy. Microeconômia: teoria, questão e aplicações. São Paulo: McGraw-Hill, 1981.

MINAYO, Maria Cecília de Souza (Organizadora). Pesquisa social. $7^{\mathrm{a}}$ ed. Petrópolis: Vozes, 1997.

OLAK, Paulo. Contabilidade de entidades sem fins lucrativos não governamentais. 1996. 273 p. Dissertação de Mestrado em Controladoria e Contabilidade - Faculdade de Economia, Administração e Contabilidade da Universidade de São Paulo. São Paulo.

. Bases para a eficácia na aplicação do contrato de gestão nas Organizações das Sociais Brasileiras. 2000. 230 p. Tese de Doutorado em Controladoria e Contabilidade - Faculdade de Economia, Administração e Contabilidade da Universidade de São Paulo. São Paulo.

OLIVEIRA, Luis Martins de. Auditoria, contabilidade e gestão de entidades mantenedoras de instituições educacionais, filantrópicas e sem fins lucrativos. Boletim do IBRACON. São Paulo, ano XXII, no 256, p. 4-15, setembro 1999.

PELEIAS, Ivam Ricardo. Controladoria gestão eficaz utilizando padrões. São Paulo: Saraiva, 2002.

PEREIRA, Carlos Alberto. Contribuição à elaboração de um modelo de mensuração aplicado aos modelos de decisão dos principais eventos econômicos de instituições financeiras: uma abordagem da gestão econômica. 2000. 321 p. Tese de Doutorado em Controladoria e Contabilidade - Faculdade de Economia, Administração e Contabilidade da Universidade de São Paulo. São Paulo.

RESOLUÇÃO CFC nº 877/2000.

SALOMON, Délcio Vieira. Como fazer uma monografia. São Paulo: Martins Fontes, 2000 . 
SANTOS, José Barreto dos. A formação profissional de Contabilidade:um processo em discussão. Revista Agora. Campo Grande, ano I, n 2, p. 29-34, outubro de 2001.

SCHRADER, Monika Sophie. Teoria e prática do planejamento universitário: $O$ caso da Universidade Católica Dom Bosco - UCDB. 1998. 235 p. Dissertação de Mestrado em Gestão Universitária - Universidade de São Marcos. São Paulo.

SILVA, Alexandre dos Santos. Análise das formas de reconhecimento da receita na contabilidade: Um enfoque no conceito econômico de lucro. 2000. 308 p. Dissertação de Mestrado em Gestão Universitária - Instituto de Estudos e Projetos de Educação Superior da Universidade São Marcos. São Paulo.

SOUZA, Paulo Renato. Enfrentar e vencer desafios. Brasília: 2000. Disponível em $<\mathrm{http} /$ www.mec.gov.br/home/ftd/sesu/enfr.doc $>$ acesso em 27.06.2002.

SZAZI, Eduardo. Terceiro setor: regulação no Brasil. São Paulo: Peirópolis, 2001.

TACHIZAWA, Takeshy. Organizações não governamentais e terceiro setor criação de ONGs e estratégias de atuação. São Paulo: Atlas, 2002.

VERGARA, Sylvia Constant. Projetos e relatórios de pesquisa em administração. $3^{\mathrm{a}}$ ed. São Paulo: Atlas, 2000.

WELSCH, Glenn A. Orçamento empresarial. São Paulo: Atlas, 1983.

http://www.senado.gov.br/servlets/NJUR.Filtro?tipo=LEI\&secao=NJUILEGBRAS\& $1 \ldots$ consulta realizada em 17/09/2002.

http://www.rits.org.br/idac.rits.org.br/idac_em3.html consulta realizada em $17 / 10 / 2002$.

http://www.previdenciasocial.gov.br/14.asp consulta realizada em 19/08/2002.

http://www.mec.gov.br/sesu/pergres.shtm consulta realizada em 19/08/2002.

http://www.universibrasil.net/postada/actualidad/notica_actualidad.jsp?noticia $=4720$ 6 consulta realizada em 05/07/2003.

http://www.estadao.com.br/agestado/notícias/2001/abr/17/329.htm consulta realizada em 05/07/2003. 
APÊNDICES 
Apêndice A - Carta de Apresentação

Campo Grande/MS, 26 de setembro de 2002.

Magnífico(a) Reitor(a)

Tenho a satisfação de apresentar o professor Emanoel Marcos Lima, aluno regularmente matriculado no Curso de Mestrado em Controladoria e Contabilidade da Universidade de São Paulo - USP, que está desenvolvendo uma pesquisa sobre as INFORMAÇÕES CONTÁBEIS DAS INSTITUIÇÕES DE ENSINO SUPERIOR PORTADORAS DO CERTIFICADO DE ENTIDADES DE FINS FILANTRÓPICOS.

Para que o mestrando possa concluir seus estudos, a colaboração de V. M. será imprescindível, mediante o encaminhamento ao setor contábil da vossa instituição, para que responda o questionário anexo e devolva até o dia 30 de outubro do corrente ano.

A pesquisa abrangerá as Instituições de Ensino Superior portadoras do Certificado de Entidades de Fins Filantrópicos. A população alvo é composta pelos contabilistas, responsáveis técnicos pelo setor contábil das instituições. A temática proposta é considerada de significativa relevância; pois, além de tratar-se de um trabalho técnico e científico os resultados poderão ser utilizados por todas as instituições de ensino superior, principalmente pelas possuidoras do Certificado de Entidade de Fins Filantrópicos.

Agradecendo, desde já, pelo apoio, aproveito a oportunidade para apresentar-lhes minhas cordiais saudações.

Pe. José Marinoni

Reitor da Universidade Católica Dom Bosco 
Apêndice B - Carta de Encaminhamento

Campo Grande/MS, setembro de 2002.

Ilmo Sr.(a)

Responsável Técnico pelo Setor Contábil

Caro(a) Colega

Na qualidade de aluno do Curso de Mestrado em Controladoria e Contabilidade, pela Universidade de São Paulo - USP, dirijo-me a V.S . na expectativa de poder contar com a sua colaboração através do preenchimento de um formulário, tipo questionário; em anexo. As informações coletadas serão fundamentais para a minha dissertação de mestrado que tem como tema: CONTRIBUIÇÃO PARA APURAÇÃO E EVIDENCIAÇÃO DOS RESULTADOS COM O CERTIFICADO DAS INSTITUIÇÕES DE ENSINO SUPERIOR COMO CERTIFICADO DE ENTIDADES DE FINS FILANTRÓPICOS.

A pesquisa abrangerá as Instituições de Ensino Superior portadoras do Certificado de Entidades de Fins Filantrópicos. A população alvo é composta pelos contabilistas, responsáveis técnicos pelo setor contábil das instituições. Sua participação é considerada de significativa relevância; pois, além de tratar-se de um trabalho técnico e científico os resultados poderão ser utilizados por todas as instituições de ensino superior, principalmente pelas possuidoras do Certificado de Entidade de Fins Filantrópicos.

Solicito que o questionário preenchido seja impreterivelmente devolvido até o dia 30 de outubro de 2002 através do envelope-resposta, para o seguinte endereço:

\section{Av. Tamandaré, 6.000 - Jardim Seminário}

Cep. 79.117-900 - Campo Grande - MS.

Setor de Auditoria

Ou através do fax n ${ }^{\circ}$ 67-326-8234

Antecipadamente, agradeço a atenção dispensada.

Contador Prof ${ }^{\circ}$. Emanoel Marcos Lima

Docente do Departamento de Contabilidade da FESCG e UCDB

Auditor Interno da UCDB

Coordenador Executivo da Fundação Tuiuiú 
Apêndice C - Questionário

\section{QUESTIONÁRIO}

Formulário para Coleta de Dados para Dissertação de Mestrado em Controladoria e Contabilidade

\section{INSTRUÇÕES PARA RESPONDER O FORMULÁRIO}

Saiba que este formulário (tipo questionário) está composto de dois tipos de questões:

a) questões com dupla possibilidade: cada respondente apenas concordará (Sim) ou discordará (Não) da questão;

b) questões com múltiplas alternativas: cada respondente escolherá uma ou mais das alternativas de cada questão.

Caso as alternativas apresentadas não representem a situação do respondente, $o$ mesmo deverá assinalar a alternativa "Outros (as)" e especificar seu entendimento sobre o assunto perguntado.

Mais uma vez, agradeço, sua colaboração.

Contador Prof ${ }^{\circ}$ Emanoel Marcos Lima

\section{IDENTIFICAÇÃO}

\section{DADOS DA INSTITUIÇÃO}

Razão Social:

Cidade: UF:

Ano de Fundação: Quantidade de Alunos:

Quantidade de Cursos Oferecidos - Graduação: Pós-Graduação:

Setor Contábil: ( ) Próprio ( ) Terceirizado 


\section{QUESTÕES}

\section{QUANTO À INSTITUIÇÃO}

01 - Quanto tempo a instituição possui o Certificado ?

( ) Até 3 anos ( ) De 3 a 5 anos ( ) Acima de 5 anos

02 - Qual a quantidade de alunos atendidos pela beneficência no ano de 2001 ?

$\begin{array}{lll}\text { ( ) Até } 500 & \text { ( ) De } 501 \text { a } 1000 & \text { ( ) Acima de } 1000\end{array}$

03 - Qual foi o valor gasto com beneficências no ano de 2001 ?

( ) Até R\$3.000.000,00 （） De R \$ 3.000.001,00 a 5.000.000,00

( ) Acima de R $\$ 5.000 .000,00$

04 - Quais as áreas de atuação da instituição?

$\begin{array}{lll}\text { ( ) } \mathrm{CCBS} & \text { ( ) CCSA CCET }\end{array}$

( ) Outros

Especifique:

05 - Em relação ao total de cursos oferecidos pela instituição, qual o percentual de cada área?

CCBS: $\%$ CCSA:__ $\%$ CCET:__ $\%$ Outros:__ $\%$

CCBS - Centro de Ciências Biológicas e da Saúde

CCSA - Centro de Ciências Sociais Aplicadas

CCET - Centro de Ciências Exatas e da Terra

\section{QUANTO AOS BENEFÍCIOS}

06 - Quais são os benefícios usufruídos em função do Certificado?

( ) INSS ( ) COFINS ( ) CSLL ( ) PIS （）IR

07-Os gastos com beneficências foram superiores aos benefícios usufruídos em 2001 ?

( ) $\operatorname{Sim}$ ( ) Não

08 - Quais as obrigações que a instituição tem para manter os benefícios do

Certificado?

( ) Aplicar 20\% da Receita Bruta Total em Beneficências

( ) Aplicar 20\% da Receita Bruta Total em Bolsas de Estudos 


\section{QUANTO ÀS INFORMAÇÕES}

09 - Como são contabilizadas as beneficências realizadas?

( ) Contas de Resultado ( ) Contas de Compensação

10 - Os custos com as beneficências são apurados?

( ) $\operatorname{Sim}$ ( ) Não

11 - Como são contabilizados os benefícios obtidos com o Certificado?

( ) Contas de resultado ( ) Contas de Compensação ( ) Não são contabilizados

12 - O resultado entre as receitas e despesas do Certificado são apuradas?

( ) $\operatorname{Sim}$ ( ) Não

13 - Se positivo, como são demonstrados?
( ) DRE
( ) Notas Explicativas
( ) Balanço
( ) Outros
Especifique:

14 - É apurado o resultado total da instituição, incluindo o resultado obtido com o Certificado?
( ) $\operatorname{Sim}$
( ) Não

15 - Quais os relatórios/informações apresentados aos administradores/dirigentes sobre as beneficências?
( ) Balanço Patrimonial
( ) D.R.E.
( ) Nenhum

( ) Outros

Especifique:

16 - Você considera que as normas estabelecidas na NBC T 10.19 do CFC podem ajudar os administradores/dirigentes na tomada de decisão?
( ) $\operatorname{Sim}$
( ) Não 


\section{APÊNDICE D}

Consulta ao Conselho Regional de Contabilidade 


\section{APÊNDICE E}

Resposta do Conselho Federal de Contabilidade 